\title{
WestVirginiaUniversity
}

THE RESEARCH REPOSITORY @ WVU

Graduate Theses, Dissertations, and Problem Reports

2010

\section{Developing a cellular assay for screening inhibitors of STAT4 phosphorylation}

\author{
Vivian Marcela Suarez \\ West Virginia University
}

Follow this and additional works at: https://researchrepository.wvu.edu/etd

\section{Recommended Citation}

Suarez, Vivian Marcela, "Developing a cellular assay for screening inhibitors of STAT4 phosphorylation" (2010). Graduate Theses, Dissertations, and Problem Reports. 2187.

https://researchrepository.wvu.edu/etd/2187

This Thesis is protected by copyright and/or related rights. It has been brought to you by the The Research Repository @ WVU with permission from the rights-holder(s). You are free to use this Thesis in any way that is permitted by the copyright and related rights legislation that applies to your use. For other uses you must obtain permission from the rights-holder(s) directly, unless additional rights are indicated by a Creative Commons license in the record and/ or on the work itself. This Thesis has been accepted for inclusion in WVU Graduate Theses, Dissertations, and Problem Reports collection by an authorized administrator of The Research Repository @ WVU. For more information, please contact researchrepository@mail.wvu.edu. 
Developing a cellular assay for screening inhibitors of STAT4 phosphorylation

Vivian Marcela Suarez

Thesis submitted to the College of Engineering and Mineral Resources

at West Virginia University in partial fulfillment of the requirements

for the degree of

Master of Science

In

Chemical Engineering

David Klinke, PhD., Chair

John Barnett, PhD.

Robin Hissam, PhD.

Department of Chemical Engineering

Morgantown, West Virginia

2010

Keywords: T-cells, Signaling, Activation, Phosphorylation, Cytokines 


\section{ABSTRACT \\ Developing a cellular assay for screening inhibitors of STAT4 phosphorylation \\ Vivian Marcela Suarez}

In order to design better therapeutic strategies, scientists work on understanding the interactions that take place at cell level and have an effect on the immune system. In order to identify a few possible inhibitors that may be up-regulated in tumor environment and that may affect T-cell action, a cellular assay was designed. An Interleukin-12 (IL-12)-responsive murine Th1 cell clone called 2D6 was used as cellular model to study the effects of transforming growth factor- $\beta$ (TGF- $\beta$ ), insulin, and interleukin-6 (IL-6) on the phosphorylation of Signal transducer and activator of transcription 4 (STAT4), a key element in IL-12 signaling. Cells were IL-12-starved for 12 hours and then were treated for 15 minutes, 1 hour and 2 hours with one of these factors and/or IL-12 and the cell samples were analyzed by flow cytometry. In general, TGF- $\beta$ and insulin had a significant effect in the phosphorylation of STAT4 and cell viability particularly after 2 hours in cells incubated with these factors only. While more subtle, the effects of IL-6 also seemed to be have a stronger effect after 2 hours of treatment. The assay designed was able to provide with answers about inhibition of IL-12 signaling in a relatively restricted time frame, but more questions need to be answered to fully understand the effect of each factor, for which a new experimental approach may be needed. 


\section{ACKNOWLEDGEMENTS}

Dr. David Klinke for his mentoring, guidance and understanding through the hard process of my learning of Biology and how to connect it to Engineering.

The members of my committee, Dr. John Barnett and Dr. Robin Hissam for their support and feedback.

Dr. Kathleen Brundage for the processing of the samples in the Flow Cytometry Core Facility and for her knowledge and insight.

Emily Chambers, Dr. Meenal Elliot, Dr. Ida Holaskova, Dr. Yogesh Kulkarni, Ewa Lukomska, Dr. Rosana Schafer and Dr. Marcela Whetsell for being there with an answer or simply a friendly smile.

My husband for his endless capacity of patience, for giving me strength and dealing with my stress breakouts and tantrums, and my Mom for praying every day for me.

All my friends who ever saw me stressing over school and research and gave me any kind of support, and everyone else who feels they contributed in any way to this somewhat painful process. 


\section{Table of Contents}

ABSTRACT Aist of Tables




\section{List of Tables}

Table 1. Fluorescence spectra of fluorophores used.

Table 2. Spillover matrix of FITC and Alexa Fluor 647 channels............................. 19

Table 3. P-values from two-way ANOVA for analysis of TGF- $\beta$ experiments. ............ 29

Table 4. P-values from two-way ANOVA for analysis of insulin experiments. ........... 34

Table 5. P-values from two-way ANOVA for analysis of IL-6 experiments. ............... 38 


\section{List of Figures}

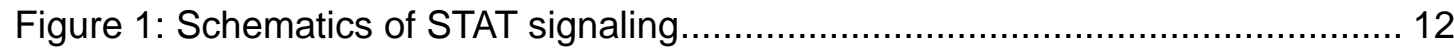

Figure 2. Signaling events downstream of TGF- $\beta$ association to receptor .............. 14

Figure 3. Signaling events upon insulin binding at cell surface.............................. 14

Figure 4. Forward and side scatter of 2D6 cells at time -12 hours (i.e. before IL-12

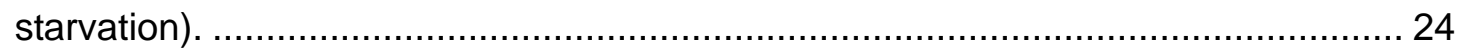

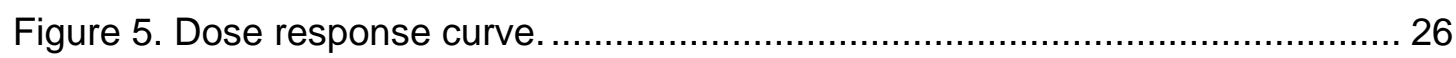

Figure 6. Single stain control histograms........................................................... 26

Figure 7. Representative plot of phosphorylated STAT4 versus IL-12Rß2 upon

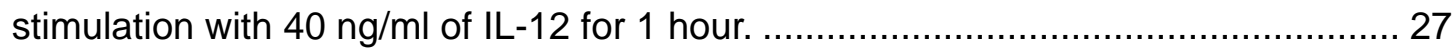

Figure 8. Time course of pSTAT4 expression in different treatment groups with TGF-

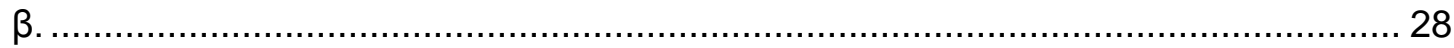

Figure 9. Median fluorescent intensities of pSTAT4 per time point. ......................... 29

Figure 10. Time course of cell viability in different treatment groups of TGF- $\beta \ldots \ldots . . . .30$

Figure 11. Cell viability per time point. ............................................................. 30

Figure 12. Time course of pSTAT4 expression in different treatment groups with

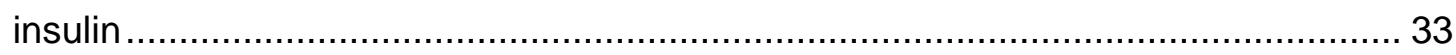

Figure 13. Median fluorescent intensities of pSTAT4 per time point. ....................... 34

Figure 14. Time course of cell viability in different treatment groups of insulin ......... 35

Figure 15. Cell viability per time point. ........................................................ 35

Figure 16. Time course of pSTAT4 expression in different treatment groups with

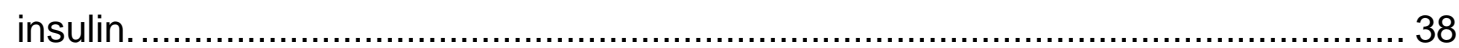

Figure 17. Median fluorescent intensities of pSTAT4 per time point. ....................... 39

Figure 18. Time course of cell viability in different treatment groups of IL-6. ........... 39

Figure 19. Cell viability per time point. ............................................................. 40

Figure 20. Western blot to observe pSTAT3 in 2D6 cells upon treatment with IL-6. . 41 


\section{CHAPTER ONE: \\ INTRODUCTION}

As more knowledge is gained on the ins and outs of the immune system it becomes more clear that the mechanisms for the defense against disease and pathogens engages a plethora of intermolecular interactions that lead to a final effect in the organism. Based on these interactions, scientists work on developing therapeutic strategies for the treatment of diseases that either trigger or block certain interactions at cell level. The design of such molecular triggers/stops (i.e. drugs) requires a good understanding of the effects of changes in interactions such as protein signaling in order to be able to manipulate them. It is also important to visualize the signaling events as part of a whole, and to understand that the components may receive signals from more than one source at a time, leading to an action that may result from this crosstalk of signals. In order to study this complex of signals and responses, a model cell line from the immune system was used to develop a cellular assay that would mimic the presence of different factors in the tumor microenvironment where there can be overexpression of many molecules, and to quantify the inhibiting effect that such factors could have on the cell's mechanism of action. 


\section{CHAPTER TWO: \\ LITERATURE REVIEW}

\subsection{Innate immune system}

One of nature's most amazing systems is the complex network that encompasses all the structures and processes that take place in an organism to protect and defend it from external agents that may pose a threat. The first line of defense after the protective barriers (skin, mucus, proteases and gastric acid in stomach, etc) have been crossed by pathogens is the innate system that is said to be non-specific although triggered when the pattern-recognition receptors (PRRs) identify microbes. These PRRs have evolved so that they detect components in foreign pathogens, called pathogen-associated molecular patterns (PAMPs) (Kawai, Akira 2010). The innate response is also triggered by damaged or stressed cells that send a signal of alarm leading to the recruitment of inflammatory cells.

An important component of the innate response is the presence of leukocytes such as neutrophils and macrophages, which are phagocytes that attack pathogens and kill them by engulfing them or by mere contact. The most common type of leukocyte is the neutrophil, and the cells of this type engulf damaged tissue and bacteria and secrete proteolytic enzymes to kill microbes (VanderLaan, Reardon 2005).

Other important members of the innate response are the mast cells, which are cells that are involved in inflammation and hypersensitivity (allergy) reactions. They 
are mainly activated when degranulated upon cross-linking of the immunoglobulin $E$ ( $\lg \mathrm{E})$ to the antigen receptor (i.e. FcعR1) followed by antigen binding. After this, they release the contents of their granules, which are vasoactive substances (i.e. have an effect on blood pressure) such as histamines, proteolytic enzymes like tryptase, and inflammatory cytokines like tumor necrosis factor- $\alpha$ (TNF- $\alpha$ ). They also secrete other cytokines (proteins that carry a signal between cells) that can regulate T-cell and macrophage responses, such as interleukins 6 and 10 (VanderLaan, Reardon 2005) (Galli, Gordon \& Wershil 1991).

Some lymphocytes like the natural killer cells (NK) play an exceptionally important role in innate immunity against diseases such as cancer, due to their intrinsic ability to lyse tumor cells, hence their name (VanderLaan, Reardon 2005)(Herberman, Nunn \& Lavrin 1975). These cells are important since they provide an early response while the adaptive system mounts an effective response (Yokoyama, Kim \& French 2004). They perform cell-mediated cytotoxicity by releasing granules that contain perforin and granzymes; these proteins drill holes in cell membranes and lend to the lysis of target cells. NK cells also release cytokines that activate other effector cells such as T-lymphocytes (VanderLaan, Reardon 2005).

\subsection{The bridge between innate and adaptive immunity}

The inflammatory cascade involves several important steps such as the presentation of the antigen to T-lymphocytes. Dendritic cells (DCs) are efficient antigen-presenting cells that can regulate immune responses to foreign and selfantigens and have a unique T-cell stimulatory capacity (Heath, Carbone 2009). The 
immature dendritic cell samples the antigen by internalizing (receptor-mediated endocytosis) its particles in the form of vesicles that are subsequently fused with lysosomes and broken down. DCs also express Toll-like receptors that, upon stimulation, induce dendritic cell maturation. When mature, the cell undergoes a decrease in endocytic activity and an increase in the expression of antigenpresentation molecules (i.e. MHC I and II, CD1), costimulatory molecules and the secretion of inflammatory cytokines like Interleukin 12 (IL-12) and tumor-necrosis factor- $\alpha$ (TNF- $\alpha$ ) (VanderLaan, Reardon 2005)(Iwasaki, Medzhitov 2004)(Bobryshev 2000).

An interesting group of the cells that are members of the adaptive immune response and have receptors specific to some antigens are $ү \delta$ T-lymphocytes (see Adaptive immune system). They are a small population of T-cells that have limited diversity in their receptors, but are thought to be important in the defense against certain pathogens and can either activate or suppress other subsets of lymphocytes (VanderLaan, Reardon 2005). They produce cytokines that are also produced by the other subsets of T-lymphocytes such as interleukin 10 (IL-10) and interferon-y (IFN$\gamma)$, and unlike traditional $\alpha \beta$ T-cells they do not need antigen presentation in the context of major histocompatibility complex (MHC) molecules to respond to the antigen, which is why they are considered bridging cells in the immune system (Aljurf, Ezzat \& Mussa M. 2002).

Another intriguing subset of lymphocytes is that of the NKT cells, characterized by expressing the NK cell markers and the T-cell receptors, thus sharing 
characteristics from both innate immunity and adaptive immunity cell-type members. These cells bridge the gap between the early and late immunity by inducing NK cells to produce cytokines upon NKT activation, and by promoting B-lymphocyte proliferation and antibody production (Galli et al. 2003).

\subsection{Adaptive immune system}

The immune system has a highly sophisticated feature that confers organisms with protection against infection from most pathogens. The adaptive immune system is characterized by a genetically diverse repertoire that allows anticipation to pathogen infection by arming each lymphocyte with a unique antigen receptor that enables recognition of invaders. The system is not only anticipatory as it also remembers previous pathogen encounters that allow repelling a second invasion, or quickly elimination of the recurrent invasion by activating a faster and stronger immune response (Cooper, Alder 2006).

B-lymphocytes play an important role in establishing and maintaining the protective immunity, as they produce antibodies, serve as antigen-presenting cells, and have other regulatory functions (Cancro et al. 2009). B-cells can internalize the antigen via the B-cell receptor so they can present it to T-cells effectively. They also express costimulatory molecules so they can activate T-cells recognizing the same antigen, and not only produce antibodies but also secrete cytokines such as Interleukin-2 (IL-2), Interleukin-6 (IL-6) and Interleukin-12 (IL-12), IFN-ץ, transforming growth factor- $\beta$ (TGF- $\beta$ ) and TNF- $\alpha$ (VanderLaan, Reardon 2005).

T-cells are an important piece in the machinery of adaptive immunity, as they 
cover a wide range of functions essential to the defense of cells against pathogens, such as helping in the maturation of B-cells, preventing auto-immunity and destroying tumors and virally-infected cells. Antigen presenting cells (APCs), dendritic cells (DCs), B-lymphocytes and macrophages present the antigen in the form of peptides on their surface, in the groove of their major histocompatibility complex (MHC) molecule for T- cells to recognize them. Depending on their length (number of residues) these peptides can be bound by either the MHC class I molecules (8-9 residue-peptides) commonly expressed across cell types or to MHC class II molecules (13-17 residue-peptides) expressed by APCs only (Rudenski et al. 1991). In MHC class I presentation the peptides presented are derived from endogenous proteins that have been processed via a ubiquitin-driven proteolytic system. In MHC class II presentation, the peptides presented are derived from exogenous proteins, internalized via endocytosis and processed via the proteolytic system. Cytotoxic Tlymphocytes (CTLs) respond to specific epitopes presented through the MHC class I pathway. Cluster-of-differentiation-4-positive (CD4+) T-cells respond to specific epitopes presented through the MHC class II pathway (Gerloni et al. 2004).

T-cells may express either a $\alpha \beta$ or $\gamma \delta$ type of receptor for antigen recognition. The $\alpha \beta$ receptor recognizes peptides bound to MHC molecules. In contrast, the $ү \delta$ receptor is not as well understood (Chien, Boneville 2006), but is believed to take part by constituting a bridge between innate and adaptive immune responses (Aljurf, Ezzat \& Mussa M. 2002). Cells bearing the $\alpha \beta$ T- cell receptor (TCR) can be subdivided into cytotoxic and helper T-cells. The latter express the CD4 molecule on 
their surface and secrete cytokines after interacting with antigens presented by MHC class II molecules; they induce B-cells to proliferate and mature so they can produce antibodies. The cytotoxic T-cells express cluster-of-differentiation-8 (CD8) on their surface, and antigen presented by MHC class I molecules on a cell. Upon activation CD8+ T-cells induce apoptosis of the target cell (Davis et al. 2003). Naïve CD4+ Tcells (i.e. CD-4+ T-cells that have not been exposed to antigen) differentiate into various types of helper T-cells (Th), which can be Th1, Th2, Th17 and regulatory Tcells. Cytokines drive this differentiation into the different subtypes. Th1 cells produce IFN- $\mathrm{\gamma}, \mathrm{TNF}$ and IL-2, and are important in the defense against intracellular pathogens (Wilson, Rowell \& Sekimata 2009). Th2 cells mainly produce IL-4, IL-5 and IL-13 and are important for antibody-mediated responses for defense against extracellular parasites like helminthes. Th2 cells are also responsible for some allergic inflammatory diseases such as asthma (Paul, Zhu 2010)(Wilson, Rowell \& Sekimata 2009). The most recently discovered subset of CD4+ helper T-cells, Th17, is said to be capable of promoting chronic inflammation and tissue damage (Cua, Tato 2010). Th17 produce IL-17A, IL-17F, IL-21, IL-22 and human IL-26. They are believed to contribute to defense against extracellular bacteria and fungi (Wilson, Rowell \& Sekimata 2009). Regulatory T-cells ( $T_{\text {reg }}$ ) have the ability to suppress inflammation and induce tolerance by secreting the anti-inflammatory cytokine IL-10 and TGF- $\beta$, and inhibit the proliferation of naïve T-cells as well as reduce the helper T-cells responses(VanderLaan, Reardon 2005). 


\subsection{Phosphorylation of STAT4}

Signal transducer and activator of transcription 4 (STAT4) is a transcription factor that is activated by IL-12, and that interacts with DNA sequences in the IFN- $\gamma$ promoter region to increase this gene's transcription (Figure 1). Several studies have found that the activation of STAT4 also increases the expression of the IL-12 receptors and other cytokine receptors needed for the induction of IFN- $\mathrm{Y}$ (Morinobu et al. 2002, Lawless et al. 2000). Upon presentation of an infectious antigen, Th1 cells secrete IFN- $y$ that induces apoptosis of infected cells, and it has been found that IFN- $y$ produced by these CD4+ T-cells induces apoptosis in tumor cells (Komita et al. 2006, Wang et al. 2003).Critical evidence for this is found in studies in which tumor-bearing mice have been treated with an anti- IFN- $y$ monoclonal antibody. This treatment inhibited antitumor activity completely (Komita et al. 2006). In fact in an IFN- $\mathrm{Y}$-capture assay experiment T-cells that secreted IFN- $\mathrm{Y}$ and were enriched in vitro proved to have antitumor effectiveness in vivo, showing the strong immune power of this cytokine (Becker et al. 2001). For this reason, it is important to screen for possible inhibitors that may cause reduced signaling through STAT4 activation, and as a consequence, reduced antitumor activity via IFN-y secretion.

\subsection{T-cells and tumor microenvironment}

It is well known that the interactions of tumor cells and their microenvironment have an effect on the tumor growth and metastasis. Inflammatory cells, tumor cells and connective tissue cells all secrete cytokines that establish a complex network and contribute to the number of factors present in the tissue (Ben-Baruch 2003). The 
presence of numerous cytokines can lead to a complex environment where the immune cells may encounter stimulation and inhibition from different sources, yielding results that cannot be modeled as easily due to the presence of main factors that cause crosstalk of signaling pathways. One of the many factors that T-cells respond to is IL-12. A known T-cell stimulatory factor and main driver towards Th1 differentiation, IL-12 is a heterodimer consisting of two disulfide subunits: p35 that is similar in sequence to IL-6 and the granulocyte colony stimulating factor (G-CSF), and p40 that is highly similar to the IL-6 receptor (IL-6R) and binds to the $\beta 2$ subunit in the IL-12 receptor (IL-12Rß2)(Ling et al. 1995). IL-12-related species (IL-12p70 heterodimer, IL-12p40 monomer and IL-12(p40) $)_{2}$ homodimer) are produced mainly by DCs, and such production depends on the exposure of the cell to inflammatory mediators during differentiation and maturation (Klinke II 2006, Ebner et al. 2001). Such mediators could be Interleukin-4 (IL-4), Interferon-ү (IFN- ү), and Prostaglandin E2 (PGE2) as a few examples. The stimuli that immature DC receive in the peripheral tissues leads to the production of more mediators such as IL-12, either in its bioactive form, IL-12p70, or as the antagonizing forms that block the action of the bioactive one, IL-12p40 and IL-12(p40) $)_{2}$ (Klinke II 2007). IL-12 activation and stimulation leads to the activation of the Janus kinases Jak2 and Tyk2, which in turn phosphorylate IL-12R, serving as docking sites for the transcription factor STAT4 to be bound and phosphorylated; this is crucial in Th1 differentiation and the consequent production of IFN- $\mathrm{y}$, and thus the consequent effective elimination of pathogens and malignant molecules (Morinobu et al. 2002). 
Th17 cells differentiate form CD4+ T-cell precursors responding to TGF- $\beta$ and IL6 stimulation, which means they are independent of STAT1 and STAT4 signaling (Lee et al. 2009). The signaling of IL-6 is coupled to induction of IL-21 through signal transducer and activator of transcription 3 (STAT3) activation, which favors the development of Th17 cells (Zhou et al. 2007). Additionally, TGF- $\beta$ has been shown to stimulate Th17 cell development and to suppress Th1 and Th2 development by means of inhibiting STAT4 signaling (Mathur et al. 2007). In developing Th17 cells, the IL-23 receptor (IL-23R) is induced, whereas in Th1 cells the IL-12Rß2 is the one induced; activation of either of the receptors drives the fate of the helper T cell into Th17 or Th1: the IL-12 receptor strongly activates STAT4 signaling and the IL-23 receptor strongly activates STAT3 signaling (Lee et al. 2009); (Mathur et al. 2007). STAT4 signaling has been found to be a very important element in various diseases, such as Sézary syndrome (i.e. cutaneous lymphoma) where the absence of the IL$12 \mathrm{R} \beta 2$ leads to reduced STAT4 activation and has been correlated to the disease progression (Showe et al. 1999). It has also been identified as a key component for the mechanism of action of Chitosan-IFN-Y-pDNA Nanoparticle (CIN) therapy for the treatment of allergic asthma (Kumar et al. 2003).

Besides IL-23, it has been established that IL-6 promotes the differentiation of naïve T-cells into B-lymphocyte $T$ helper cells, by leading to secretion of IL-21, independently of Th1, Th2, or Th17 functions. It has also been established that IL-6 in combination with TGF- $\beta$ prompt the development of Th17 cells via STAT3 activation (Eddhari et al. 2009). It is known that IL-17 stimulates production of IL-6 in 
T cells and fibroblasts through a positive-feedback loop (Ogura et al. 2008) and Th17 cells are believed to promote tumor growth by producing IL-17 that promotes STAT3 activity and leads to up-regulation of antiapoptotic (i.e. prevent cell's programmed death) and angiogenic (i.e. promote development of vessels) genes (Wang et al. 2009). In fact, IL-6 has been correlated to resistance to therapy and drug-induced cell death in multiple myeloma (Burdelya et al. 2002, Frassanito et al. 2001). Additionally, STAT3 responds to IL-6 (Figure 1) by becoming phosphorylated and translocated to the nucleus to serve as transcription factor for the suppressor of cytokine signaling 3 (SOCS3), which competes with STAT4 for binding to the IL-12R, and to the Janus kinase 2 (JAK2) that phosphorylates STAT4(Yamamoto et al. 2003). Thus, it can be said that stimulation of IL-6 may lead to reduced Th1 immune response by downregulating STAT4 signaling.

A well known strategy for tumor cells to evade immunosurveillance is the downregulation of cell surface molecules involved in immune recognition, and the overexpression of the immunosuppressive cytokine TGF- $\beta$. This cytokine is overexpressed by many tumor cells, and it enhances the generation of immunosuppressive regulatory T-cells that also produce TGF- $\beta$ (Nam et al. 2008). In addition TGF- $\beta$ is known to inhibit Th1 responses by shifting T cells towards a Th2 type, which results in a less efficient immune response against tumor cells (Flavell et al. 2010)(Maeda, Shiraishi 1996). The TGF- $\beta$ receptor is composed of type I and type II receptor serine/threonine kinases on the T-cell surface. After binding of TGF- $\beta$ receptor II phosphorylates receptor I activating it to initiate signaling by 
phosphorylating Smad and leading to the activation of other kinases (Figure 2)(Shi, Massague 2003). TGF- $\beta$ is also known to inhibit IL-12 signaling in T-cells by decreasing the activity of kinases involved in the activation of transcription factors such as STATs(Bright, Sriram 1998).
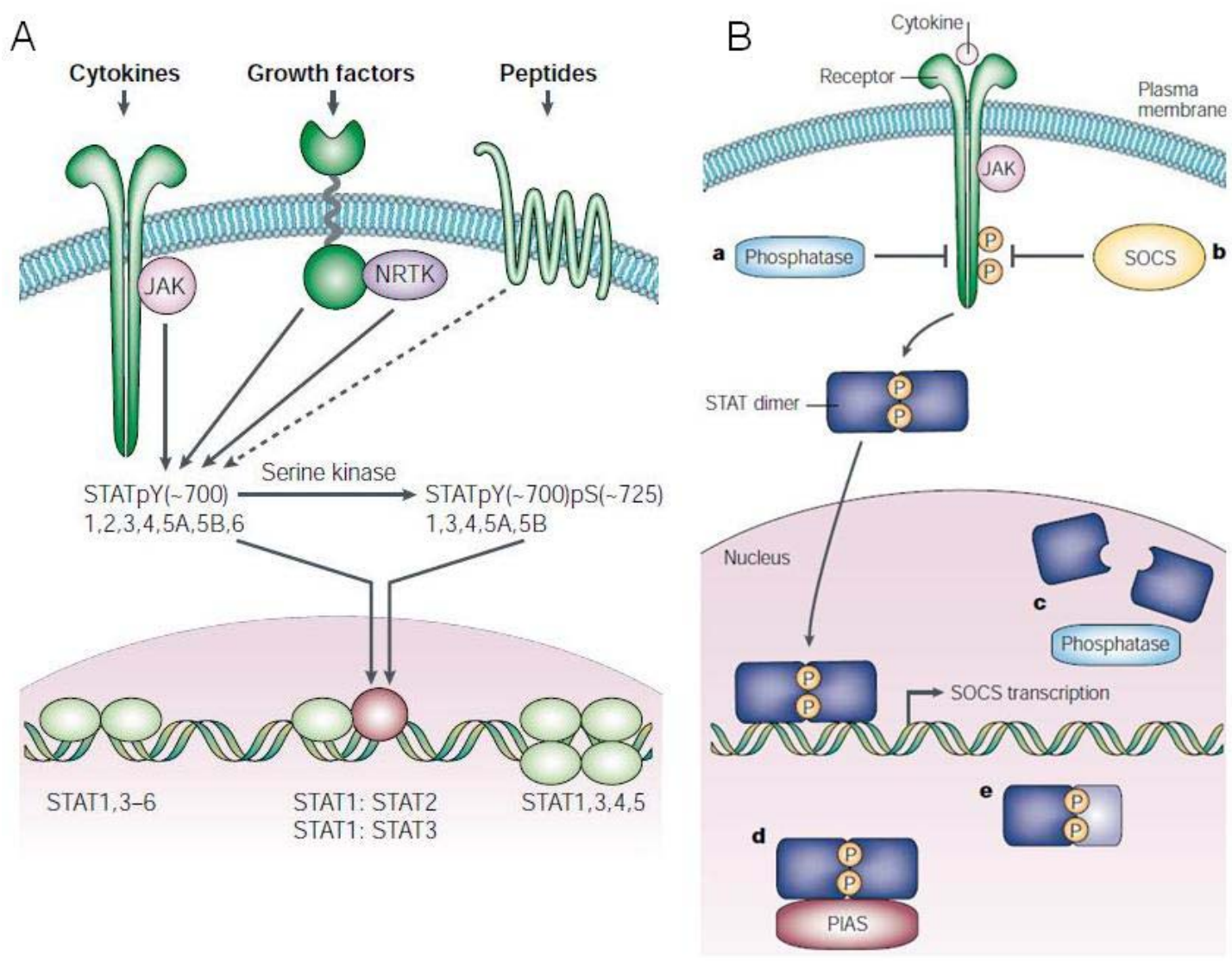

\section{Figure 1: Schematics of STAT signaling}

A. Signal transducers and activators of transcription (STAT) proteins are tyrosine phosphorylated via Janus kinases (JAKs) at around residue number 700 as a result of cytokine-receptor stimulation. STATs also receive stimuli from other receptors in an indirect way. B. Phosphatases (a) and supressors of cytokine signaling (SOCS) (b) can block STAT access to tyrosine kinase at the receptor, mediate STAT dephosphorylation (c) mediate interactions with protein inhibitors of STATs (d) or interfere with transcription by binding DNA sequence or activated STAT protein. Source:(Levy, Darnell Jr. 2002).

Upon stimulation with insulin, its binding to the insulin receptor triggers the tyrosine 
kinase activity of the latter, initiating an intracellular signaling cascade where many mitogenactivated protein kinases (MAPKs) are activated, and the insulin receptor 1 (IRS-1) is the first intracellular protein to be phosphorylated (Orcy et al. 2005)(Sykiotis, Papavassiliou 2001). As insulin binds its receptor on the cell-surface, the latter becomes autophosphorylated in its $\beta$ subunits and this confers the receptor with tyrosine kinase abilities that phosphorylated insulin receptor subtrates-1 and-2 (IRS-1 and IRS-2, respectively) (Figure 3). These phosphorylation events generate docking sites for molecules such as phosphatidylinositol-(PI)-3-kinase among others, leading ultimately to the stimulation of the MAPK/ERK kinase (MEK) and ERK (Desbois-Mouthon et al. 1998). It is known that phosphorylation of p38 MAPK and c-Jun Nterminal kinase (JNK) favors T-cell polarization toward Th1, and phosphorylation by extracellular-signal regulated kinases (ERK) leads to polarization of T-cells toward Th2(Viardot et al. 2007, Dong, Davis \& Flavell 2002). As a consequence, continuous activation of the insulin pathway that would cause activation of ERK and inhibition of p38 and JNK, would lead to favored polarization into Th2 cells, decreasing the IFN-y to IL-4 ratio as a consequence of decreased phosphorylation of STAT4 (Viardot et al. 2007). However it is not clear yet whether insulin exerts an inhibitory effect on IL-12 signaling since its role as an inhibitor remains relatively unknown. 


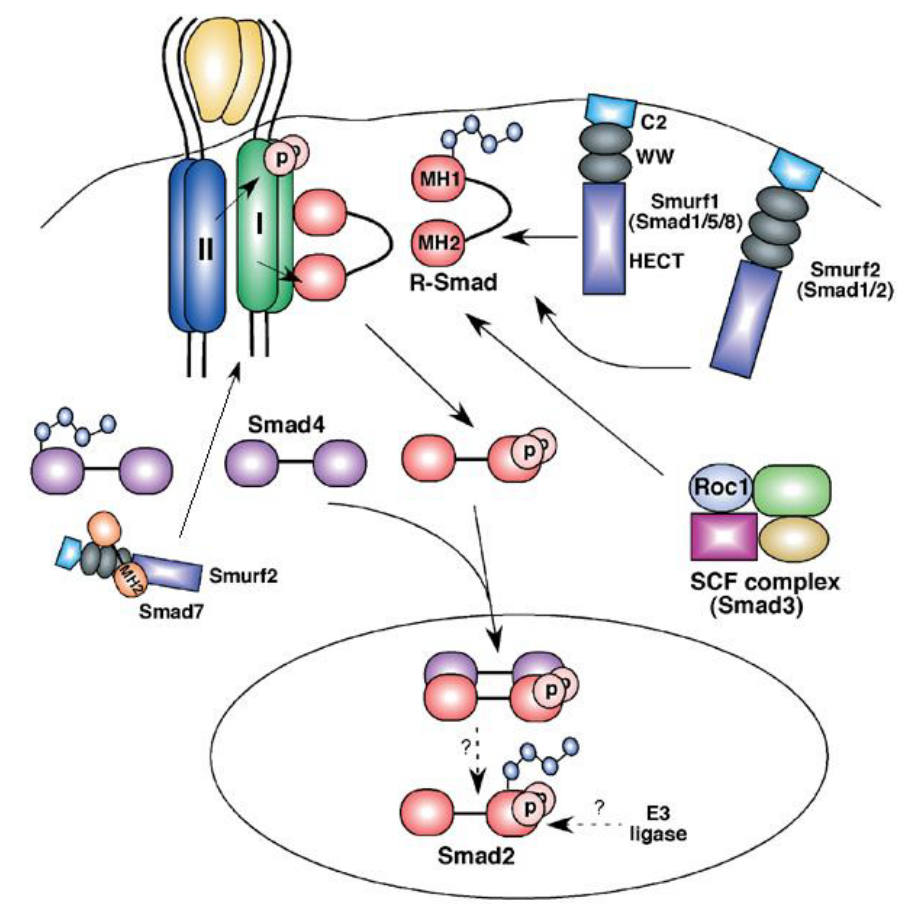

Figure 2. Signaling events downstream of TGF- $\beta$ association to receptor

Receptor type II initiates the signaling cascade by phosphorylating receptor I followed by the subsequent activation of Smad proteins. Smad 7 regulates signaling by binding to the receptor and causing its degradation. Source:(Izzi, Attisano 2004).

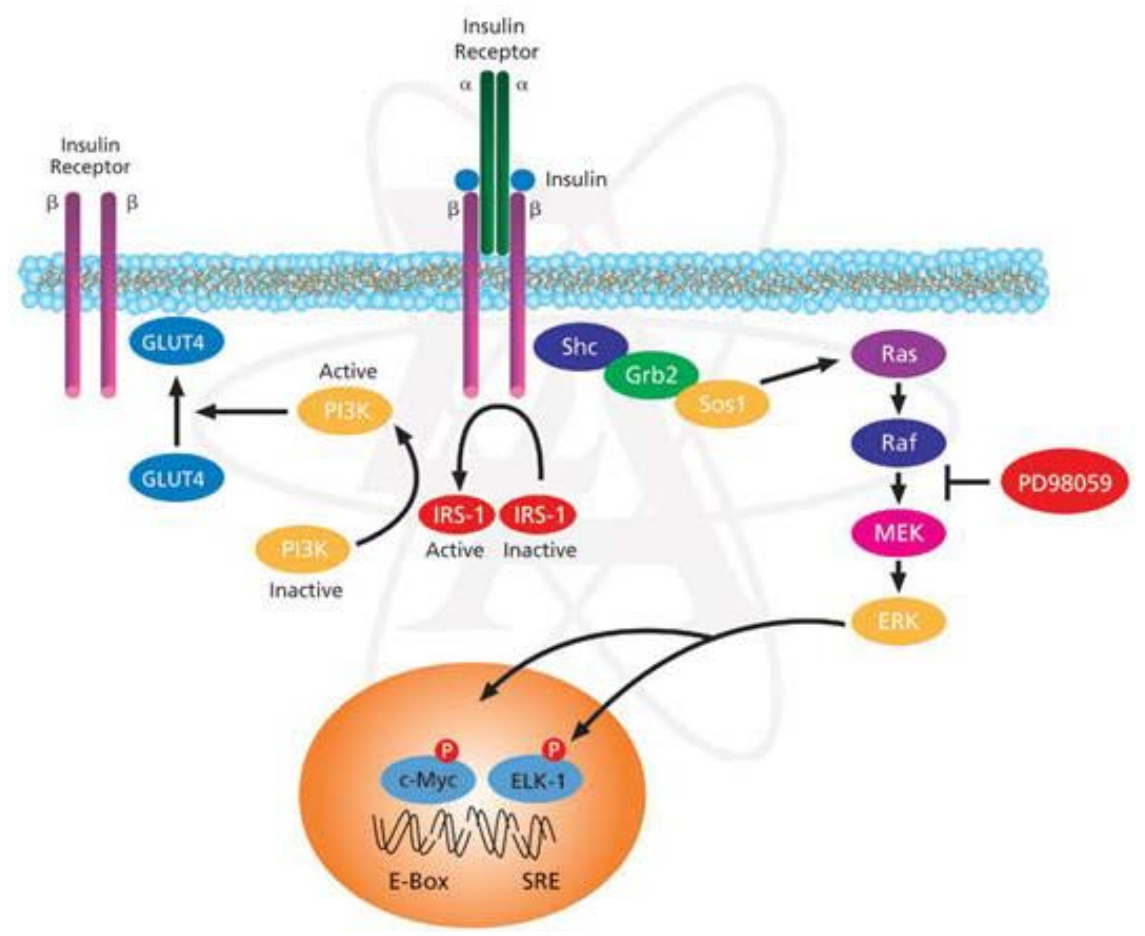

Figure 3. Signaling events upon insulin binding at cell surface

As insulin binds the receptor, the latter becomes activated and phosphorylates insulin receptor substrates-1 and-2 initiating a cascade that activates MAP kinases. Source: http://sigmaaldrich.com 
Based on all this evidence suggesting crosstalk of different signaling pathways, it was hypothesized that the presence of either TGF- $\beta$, IL-6 or insulin at high levels in the cell's environment would lead to decreased STAT4 phosphorylation and in consequence, a less functional helper T-cell. The objective of this work was to develop an assay to study the effect of some of these factors encountered in tumor microenvironment on the immune response of Th1 cells via STAT4 activation, and to establish the significance of the presence or not of such crosstalk in the immune system. 


\section{CHAPTER THREE: \\ MATERIALS AND METHODS}

\subsection{Cell lines and tissue culture}

The cell line 2D6, a Th1-cell clone from mice, was kindly provided by Dr. M. Grusby (Harvard University, Cambridge, MA, U.S). The cells were kept in $25 \mathrm{~cm}^{2}$ tissue culture flask with $15 \mathrm{ml}$ cell culture media and supplemented with or without 6.7ng/ml recombinant Mouse IL-12p70 (eBioscience, San Diego, CA, U.S.). The tissue culture media consisted of RPMI-1640 supplemented (SRPMI) with 10\% Fetal Bovine Serum (FBS) (Atlanta Biologicals, Lawrenceville, GA, U.S.), 100 I.U./ml Penicillin/Streptomycin, (Biowhittaker, Walkersville, MD, U.S.), 1\% of $200 \mathrm{mM} \mathrm{L-}$ Glutamine (Mediatech, Manassas, VA, U.S.), 1\% of Non-Essential Amino Acids 100X (Chemicon International, Temecula, CA, U.S.A.), 1\% of 100mM Sodium Pyruvate (MP Biomedicals, Solon, OH, U.S.A.), 1\% of 1M HEPEs (Fisher Bioreagents, Pittsburgh, PA, U.S.), and $2 \mu$ l of b-mercaptoethanol (Sigma Chemical, St. Louis, MO, U.S.). Tissue culture media was replaced every 24 hours and cells were cultured at $37^{\circ} \mathrm{C}$ with $5 \% \mathrm{CO}_{2}$.

\subsection{Antibodies and Reagents}

Purified Hamster Anti-Mouse IL-12 Receptor B2, Fluorescein isothiocyanate (FITC)-conjugated Mouse Anti-Armenian and Syrian Hamster IgG1 (G94-56), Alexa Fluor 647-conjugated Mouse Anti-Stat4 (pY693), Alexa Fluor 488 Mouse anti-Stat3 (pY705), BD Phosflow lyse/fix buffer 5X, and BD Phosflow Perm Buffer III were purchased from BD Biosciences (San Diego, CA, U.S.). ChromPure Mouse IgG 
(whole molecule) and ChromPure Rat IgG (whole molecule) were purchased from Jackson Immuno Research (West Grove, PA, U.S.). DPBS 1X and RPMI-1640 were purchased from Mediatech (Manassas, VA, U.S.). Sodium Azide (Na Azide) was purchased from United States Biochemical Corp (Cleveland, OH, U.S.).

\subsection{Stimulation of IL-12 signaling}

IL-12 and/or other cytokine stimulation: Cells were cultured in 96-well U -bottom plate for 12 hours with SRPMI media without IL-12 before stimulation, at a cell density of $6 \times 10^{4}$ cells/well. Either different concentrations of IL-12 (10, 40 and $\left.100 \mathrm{ng} / \mathrm{ml}\right)$ or $10 \mathrm{ng} / \mathrm{ml}$ of IL-6, TGF- $\beta$ or insulin (each alone or together with $40 \mathrm{ng} / \mathrm{ml}$ of IL-12), were added into IL-12 treatment groups 12 hours later, DPBS was added into negative controls. The cells were cultured for 15 minutes, 1 and 2 hours, and samples at time --12 hours (before IL-12 depletion) and time 0 (after 12 hours of IL12 depletion) were collected.

For all situations, at each time point (-12 hours, 0 hours, 15 minutes, 1 hour, 2 hours) supernatant for each well was taken and stored at $-20^{\circ} \mathrm{C}$. Pre-warmed Phosflow lyse/fix buffer was added into each well and incubated at $37^{\circ} \mathrm{C}$ for 10 minutes. Then, $200 \mu \mathrm{l}$ of DPBS were added into each well. The plates were stored at $4{ }^{\circ} \mathrm{C}$ until stained for flow cytometry. The experiment was performed in triplicate, cells were cultured at $37^{\circ} \mathrm{C}$, and $5 \% \mathrm{CO}_{2}$.

\subsection{Flow cytometry}

Flow cytometry is a technique used to analyze large numbers of cells in short time $(-10,000$ cells/s) that relies on hydrodynamic focusing to inject the cell suspension into a sheath stream inside a flow cell (Rieseberg et al. 2001). A laser 
beam is directed toward the cell and the light scattered in all directions is collected by filters and detectors. The voltage pulses generated by the light scattering are counted and correlated to cell size (small angle of forward scatter) and internal complexity and granularity of the cell (large angle or side scatter). Hydrodynamic focusing ensures that only one cell at a time passes through the laser beam. Fluorophores can be used to label molecules such as antibodies specific to molecules within the cell or on its surface as the appropriate laser wavelength will excite it and cause it to emit light that can be detected as well.

Treated cells were prepared, as described in 3.3, and stained with proper fluorophore-conjugated antibodies specific for IL12RB2 and phosphorylated STAT4 (pSTAT4).

Treated cells were permeabilized by incubating them with chilled Phosflow Perm Buffer III for 30 minutes on ice, and subsequently washed twice with ice cold PBSAZ. Cells were incubated with ChromPure Mouse IgG and ChromPure Rat IgG (Block Reagent) on ice for 15 minutes to block non-specific IgG binding sites. Subsequently, the cells were washed with PBSAz once, incubated with appropriate antibodies conjugated to a fluorophore (Table 1) for 30 minutes in the dark and at room temperature. The same process was repeated for all selected antibodies. Finally, the cells were washed with PBSAz three times and transferred into $5 \mathrm{ml}$ tubes containing PBSAz for flow cytometry analysis. No stain controls were used as negative flow cytometry controls, and single stained controls were used to assess the fluorescence spill over. To make up for any possible spectral overlap of the fluorescence excitation 
and emission spectra for the fluorophores used, the spectral spillover was estimated as shown in the spillover matrix (Table 2). These values were calculated from singlestained controls as described by Klinke (Klinke, Brundage 2009). The spillover matrix was used to correct raw fluorescent intensity observed in cells stained with more than one fluorophore, so that the scatter plots of single stained controls after spectral overlap were removed using the compensation matrix. Unstained controls provided an estimate of background fluorescence for all the channels. So for instance, after compensation for spectral analysis, the sample stained with a fluorescently labeled antibody against phosphorylated STAT4 (Alexa Fluor-647) should show an increase above background only for the pSTAT4 channel.

Table 1. Fluorescence spectra of fluorophores used.

\begin{tabular}{|c|c|c|}
\hline Fluorophore & Excitation peak (nm) & Emission peak (nm) \\
\hline FITC & 495 & 520 \\
\hline Alexa Fluor 647 & 650 & 668 \\
\hline
\end{tabular}

Table 2. Spillover matrix of FITC and Alexa Fluor 647 channels.

\begin{tabular}{c|c|c|}
\multicolumn{1}{c}{ FITC (IL-12Rß2) } & \multicolumn{1}{c}{ Alexa Fluor 647 (pSTAT4) } \\
\cline { 2 - 3 } FITC (IL-12Rß2) & 1 & 0 \\
Alexa Fluor 647 (pSTAT4) & 0 & 1 \\
\cline { 2 - 3 } & &
\end{tabular}

Data Analysis

The flow cytometry raw data were analyzed with R/Bioconductor (see Appendix A) to obtain compensation and transformed values of the median fluorescent 
intensities for each parameter measured (i.e. pSTAT4).

A two-way ANOVA was applied at each time point to compare the effect of each potential inhibitor to the effect of IL-12 on pSTAT4 median fluorescent values and live cell percent values. P 0.05 was taken as a point of significance. The statistical analysis was done with the Minitab 15 Statistics Software.

\subsection{Western Blot}

The Western Blot technique allows the detection of proteins from a tissue or extract sample by molecular weight. Cells are broken by mechanical methods such as sonication and detergents and buffers are used to lyse them and solubilize the protein sample. The proteins are then separated by gel electrophoresis mostly sodium dodecyl sulphate - polyacrylamide gel electrophoresis (SDS-PAGE), in which reducing agents are used to denature proteins by removing secondary and tertiary structures. The SDS is negatively charged and coats the protein to protect its denatured structure, and so the protein migrates through the acrylamide gel towards the positively charged electrode. The samples are loaded onto the gel into wells, and when voltage is applied the proteins migrate at different velocities according to size (i.e. smaller molecular weight proteins migrate faster) separating into bands on a lane. Once separated, the proteins are transferred onto a nitrocellulose or polyvynilidene difluoride (PVDF) membrane by means of an electric current that pulls the proteins into the membrane in the exact same location and distribution they had within the gel. The membrane is blocked with a generic protein such as bovine serum albumin (BSA) or non-fat dry milk to avoid unspecific binding of antibodies used for 
detection to the membrane. For detection the membrane is incubated overnight at cold temperature in a dilute solution of primary antibody from an animal source that is specific to the protein of interest. The membrane is then washed and incubated in a dilute solution of secondary antibody directed toward the species of origin of the primary antibody. The secondary antibody is usually linked to an enzyme that cleaves a chemiluminescent agent so the bound complex can be detected by film exposure. Some other secondary antibodies are bound to a fluorophore or fluorescent label so a scanner with a CCD camera (i.e.photosensor) that has appropriate emission filters can capture a digital image of the membrane for analysis.

Cells were cultured and treated as explained on section 3.3 for stimulation with each potential inhibitor (TGF- $\beta$, insulin, IL-6) at a cell density of $6 \times 10^{7} / \mathrm{ml}$. Cells were pelleted and resuspended in $1 \mathrm{ml}$ of cold DPBS. Then the cell suspension was centrifuged for 30 seconds and pelleted again, and the pellet was resuspended in $500 \mu$ of cold Cell Lysis Buffer (90\% double distilled water, $2 \% 1 \mathrm{M}$ Tris $(\mathrm{pH} 7.66), 3 \%$ $5 \mathrm{M} \mathrm{NaCl}, 0.2 \%$ 0.5M EDTA, 1\% 0.1M EGTA, 1\% Triton X-100, $2.5 \% 0.1 \mathrm{M}$ Sodium pyrophosphate, $0.5 \%$ Sodium orthovanadate, $2.5 \% 1 \mathrm{mg} / \mathrm{ml}$ leupeptin) and incubated on ice for 5 minutes. Cells were then sonicated 4 times for 5 seconds each, and centrifuged for 10 minutes at $4^{\circ} \mathrm{C}$. The supernatants were transferred to new tubes (around $250 \mu \mathrm{l}$ per tube) and the lysates were stored at $-70^{\circ} \mathrm{C}$. The lysates were loaded onto an acrylamide gel together with a Stat3 control cell extract (Cell Signaling Technology, Inc.) and a molecular weight marker (Odysssey Two-Color Protein Molecular Weight Marker, Li-Cor Biosciences, Lincoln, Nebraska, USA). The 
lysates were separated by gel electrophoresis and blotted onto a PVDF membrane (see Appendix D). The membrane was blocked with Odyssey ${ }^{\circledR}$ Blocking Buffer (LiCor Biosciences, Lincoln, Nebraska, USA) and probed with antibodies against pSTAT3 and an antibody against glyceraldehyde 3-phosphate dehydrogenase (GAPDH) as a loading control (GAPDH (FL-335), Santa Cruz Biotechnology, Inc., Santa Cruz, California, USA). Phosphorylated STAT3 was detected by use of a rabbit anti-Phospho STAT3 (Y705) (Cell Signaling Technology, Inc.) primary antibody, and IRDye $^{\circledR}$ 800CW Conjugated Goat (polyclonal) anti-rabbit IgG secondary antibody. The proteins were imaged with the Odyssey ${ }^{\circledR}$ Infrared Imaging System (Li-Cor Biosciences, Lincoln, Nebraska, USA). 


\section{CHAPTER FOUR: \\ RESULTS AND DISCUSSION}

\subsection{Effect of potential inhibitors on STAT4 phosphorylation}

In order to address the response of $T$ cells to the presence of possible inhibitors in the tumor microenvironment, the 2D6 cell line derived from a mouse Th1 cell clone was cultured at a cell density of $6 \times 10^{4}$ cells/well and deprived of IL-12 for a period of 12 hours. Following this period of starvation, they divided into four treatment groups: treated with IL-12 only, treated with the potential inhibitor of STAT4 phosphorylation (i.e. TGF- $\beta$, Insulin, IL-6) only, treated with both insulin and the potential inhibitor, or with no treatment. The appropriate cells were stimulated with either $10 \mathrm{ng} / \mathrm{ml}$ TGF- $\beta$ (Zheng et al. 2002),(Hanafusa et al. 1999), $10 \mathrm{ng} / \mathrm{ml}$ insulin (Viardot et al. 2007) or 10 ng/ml IL-6 (Nakagawa et al. 2009)(Takeda et al. 1998) for 15 minutes, 1 hour or two hours. The results are representative of at least two biological replicates.

\subsubsection{Gating for cell population}

To exclude dead cells and non-cellular debris from the flow cytometric analysis, the forward and side scatter characteristics of the observed events for each sample was used to identify live cells by means of R/Bioconductor analysis. Reduced cell size (i.e., reduced forward scatter) and an increase in cellular granularity (i.e., an increase in side scatter) correlate with cell death. As a representative sample, the forward and side scatter plot for cells at -12 hours (i.e. cells before IL-12 depletion) is shown in 
Figure 4. Live cells used in subsequent analysis were identified using a data-driven gate as enclosed by the red circle: the blue dots stand for each individual cell, the red circle encloses $95 \%$ of the population used for subsequent analysis.

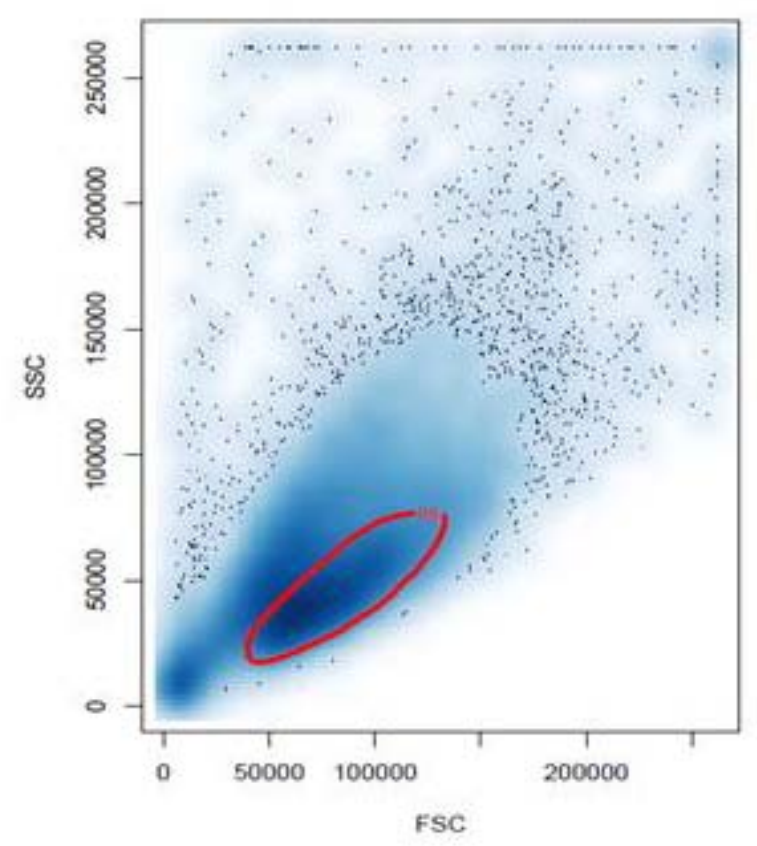

Figure 4. Forward and side scatter of 2D6 cells at time -12 hours (i.e. before IL-12 starvation).

Blue dots represent individual cells, and $95 \%$ of the population used for analysis is enclosed in the red circle.

\subsubsection{Response of $2 \mathrm{D} 6$ cells to cytokine stimuli}

To assess for the optimal dose of IL-12 to obtain a maximum response of the IL12 signaling pathway in 2D6 cells, the activation of STAT4 was measured after stimulation with different concentrations of IL-12. Such parameter was measured by flow cytometry using an antibody for the phosphorylated STAT4 (Table 1). The optimal concentration determined was used in subsequent experiments.

Since the levels of expression of IL-12R 32 correlate positively with STAT4 activation upon IL-12 stimulation as found in a previous study from our research group (Finley et al. 2010), the presence of IL-12Rß2 was observed in each 
experiment as a internal control by flow cytometry using the appropriate antibodies (Table 1).

A statistical data-driven threshold was used to define the background level of fluorescence associated with IL12R $\beta 2$ and pSTAT4, using unstained cells, and single stain controls for each (See Appendix B). The positive thresholds for IL12R $\beta 2$ and PSTAT4 were defined as the level of fluorescence for which $95 \%$ of the unstimulated cells exhibited a lower level of fluorescence. In general the distribution in Median fluorescent Intensities (MFIs) associated with IL12R $\beta 2$ and pSTAT4 exhibited unimodal distributions, as depicted by the single-stain controls used for the thresholds (Figure 6). Median value of these unimodal distributions were subsequently used to summarize dynamic changes in components of the IL-12 signaling pathway.

Following IL-12 starvation for 12 hours, samples were collected from the treatment groups at 0,15 minutes, 1 and 2 hours. A representative scatter plot of the Median fluorescent Intensity (MFI) for pSTAT4 versus IL12R $\beta 2$ is shown in Figure 6 where the MFI associated with phosphorylated STAT4 was correlated with IL12Rß2 positive cells.

\section{Dose response}

In order to establish the concentration of IL-12 to treat the 2D6 cell, a dose response was done, to evaluate the concentration for which the maximum STAT4 activation was obtained (Figure 5). Based on that, and previous findings, the concentration of 
$\mathrm{IL}-12$ used across all the experiments was $40 \mathrm{ng} / \mathrm{ml}$.

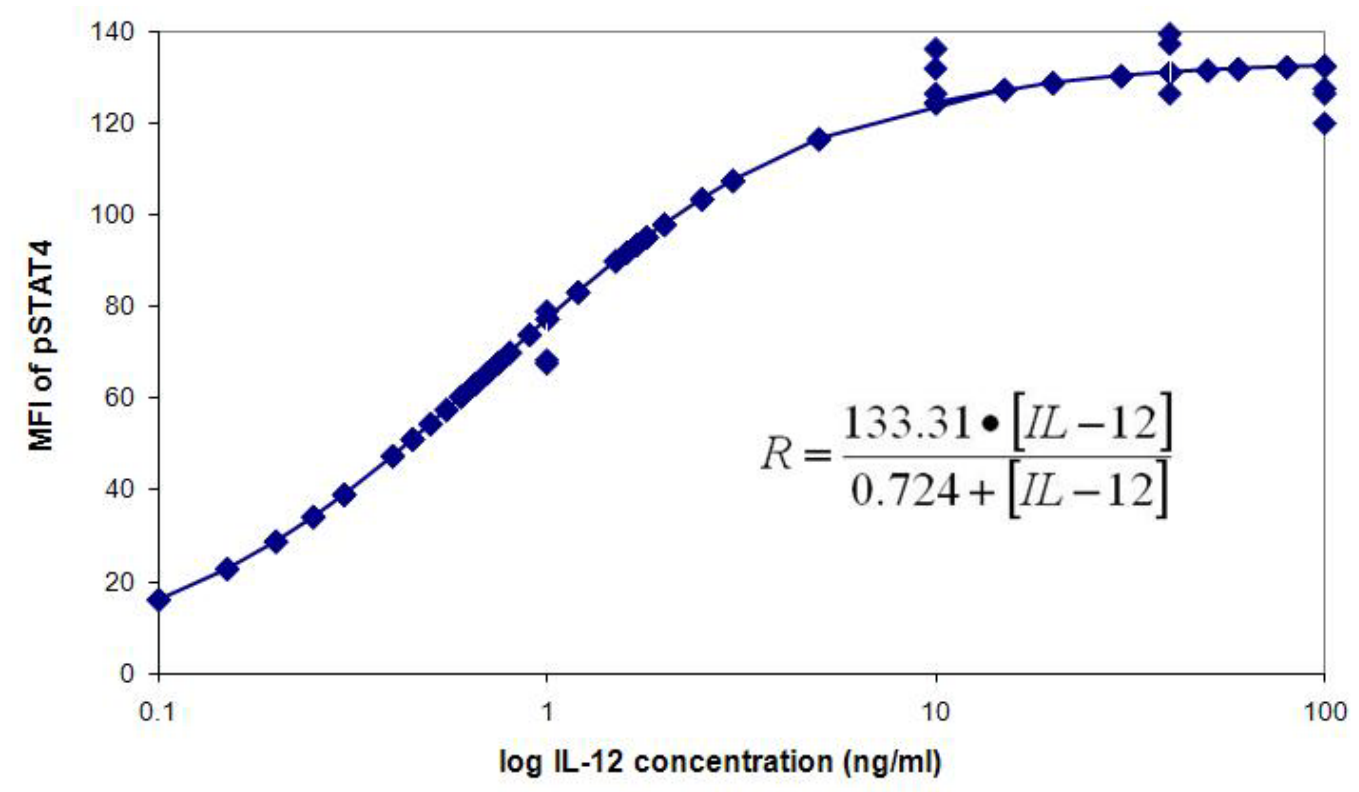

Figure 5. Dose response curve.

Response values were recorded using different concentrations of IL-12, where the response (R) corresponds to phosphorylated STAT4 upon IL-12 stimulation of 2D6 T-cells.
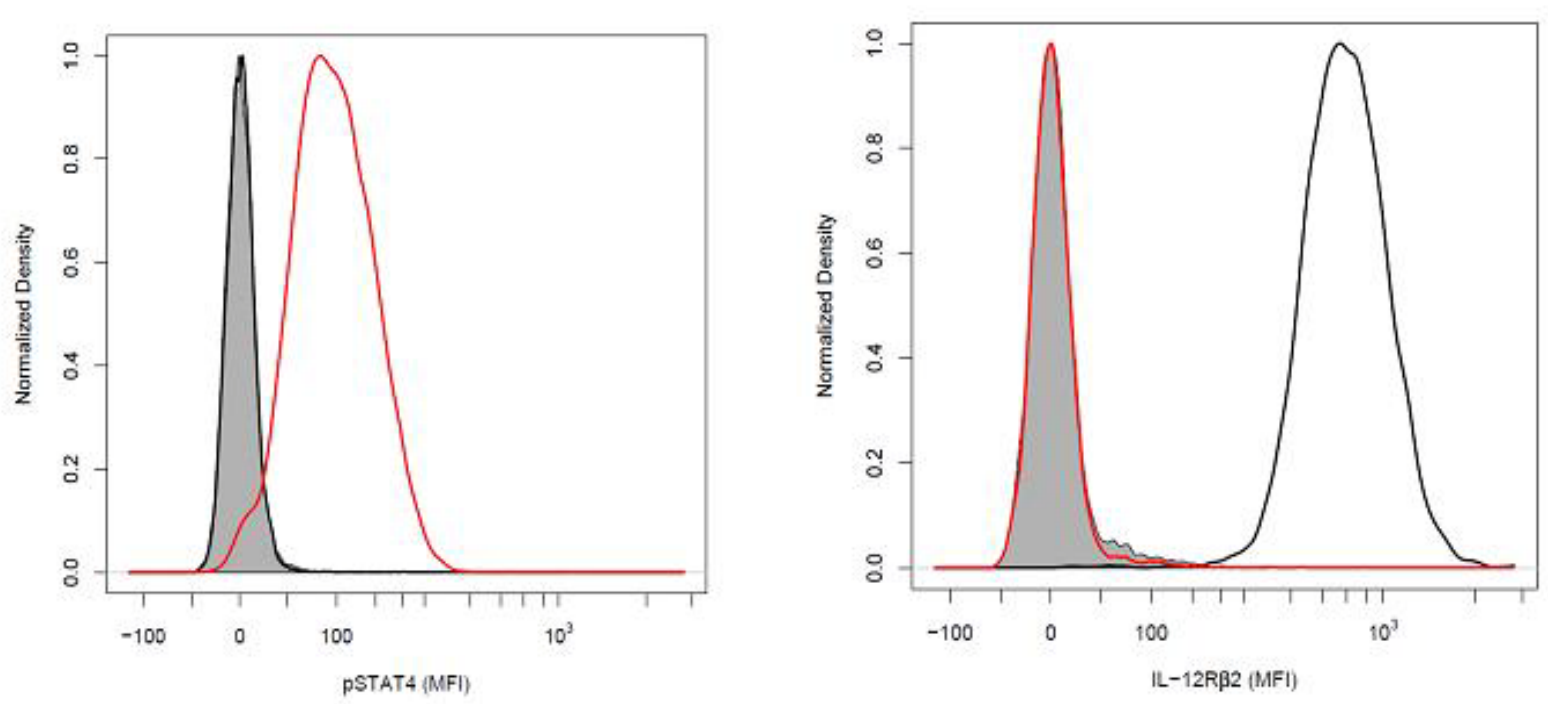

Figure 6. Single stain control histograms.

The left panel shows the histogram for PSTAT4 mean fluorescent intensity (MFI), where MFI of pSTAT4 is the $x$-axis and normalized cell density is the $y$-axis. The right panel shows the histogram for IL-12Rß2 mean fluorescent intensity (MFI), where MFI of IL-12Rß2 is the $x$-axis and normalized cell density is the y-axis. The gray polygon represents no stain control (i.e. $6 \times 10^{4}$ cells/well treated with IL-12 and no fluorescent stain), the red line represents the single stain control for pSTAT4 (i.e. $6 \times 10^{4}$ cells/well treated with IL-12 and Alexa Fluor 647 antipSTAT4 antibody), and the black line represents the single stain control for IL-12R 32 (i.e. $6 \times 10^{4}$ cells/well treated with IL-12 and FITC anti- IL-12R $\beta 2$ antibody). 

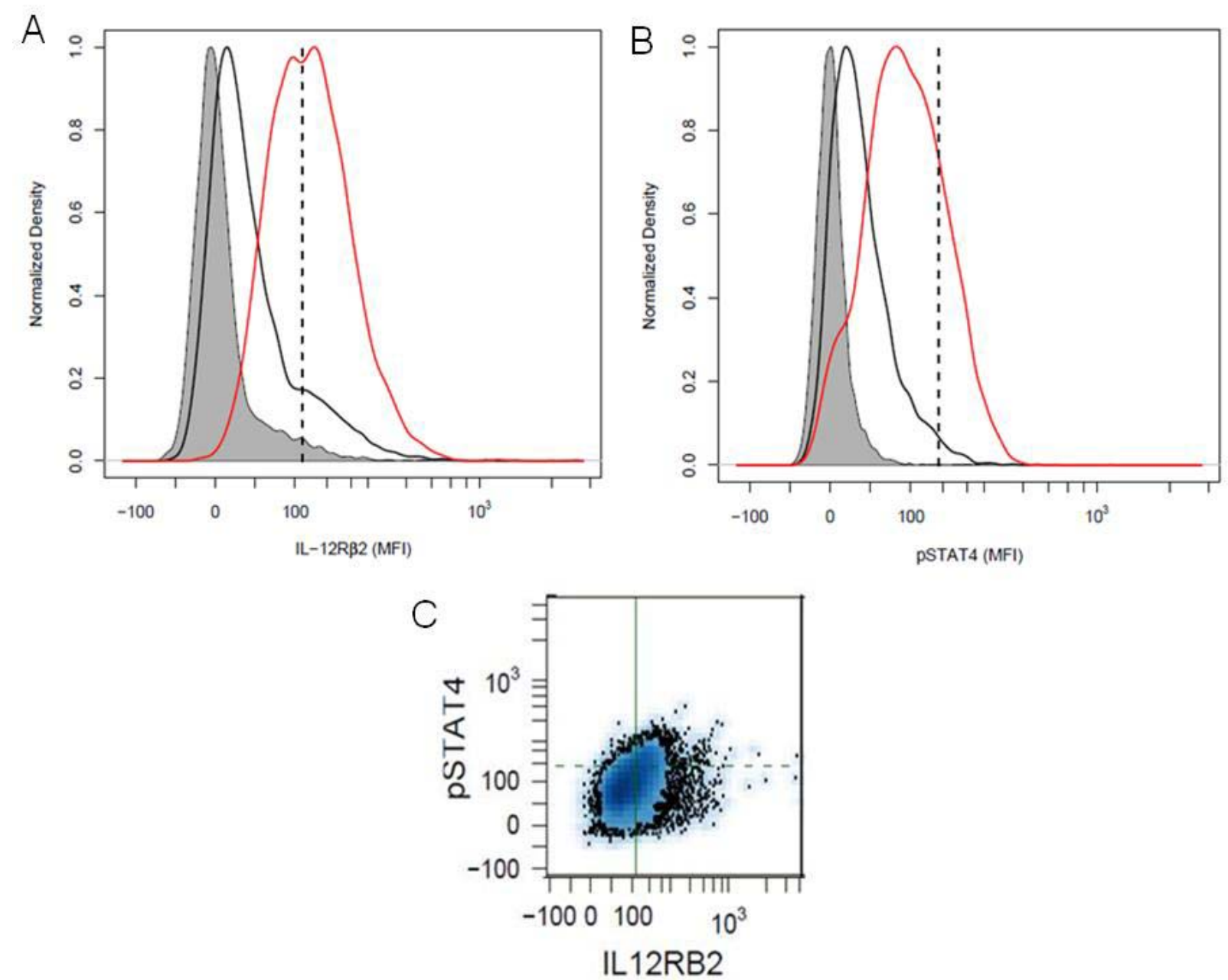

Figure 7. Representative plot of phosphorylated STAT4 versus IL-12Rß2 upon stimulation with $\mathbf{4 0} \mathbf{n g} / \mathrm{ml}$ of IL-12 for $\mathbf{1}$ hour.

The scatter plot $(C)$ represent the cell population distribution for expression of pSTAT4 and IL$12 R \quad \beta 2$. The vertical solid line represents the positive threshold for IL-12R $\beta 2$ expression observed as the vertical dashed line in panel $A$, and the horizontal dashed line represents the positive threshold for PSTAT4 expression observed as a vertical dashed line in panel B. cells positive for both molecules appear in the upper right quadrant of panel $\mathrm{C}$.

\subsubsection{Effect of TGF- $\beta$ on STAT4 phosphorylation}

The time course in the expression of pSTAT4 in 2D6 cells upon stimulation with TGF- $\beta$ is depicted in Figure 8. In general the most significant effect with respect to the unstimulated group was observed in the cells stimulated with TGF- $\beta$ (Table 3) 
particularly after two hours of incubation (See Appendix C). A decreasing trend in STAT4 phosphorylation is followed after 15 minutes and continues with time in the group treated with TGF- $\beta$ only, comparable to the trend followed by the unstimulated group. The lowest value of phosphorylation of STAT4 was reached by the latter after 2 hours of incubation (mean=44.08). The highest MFI values are displayed by the group treated with IL-12 and TGF- $\beta$, reaching a peak of STAT4 activation at 1 hour (mean=106.36) followed by a subtle decrease at 2 hours (mean=101.15). A similar trend was observed for the group treated with IL-12 only, where stimulation by this cytokine proved to have a significant effect as well on STAT4 phosphorylation (Table 3).

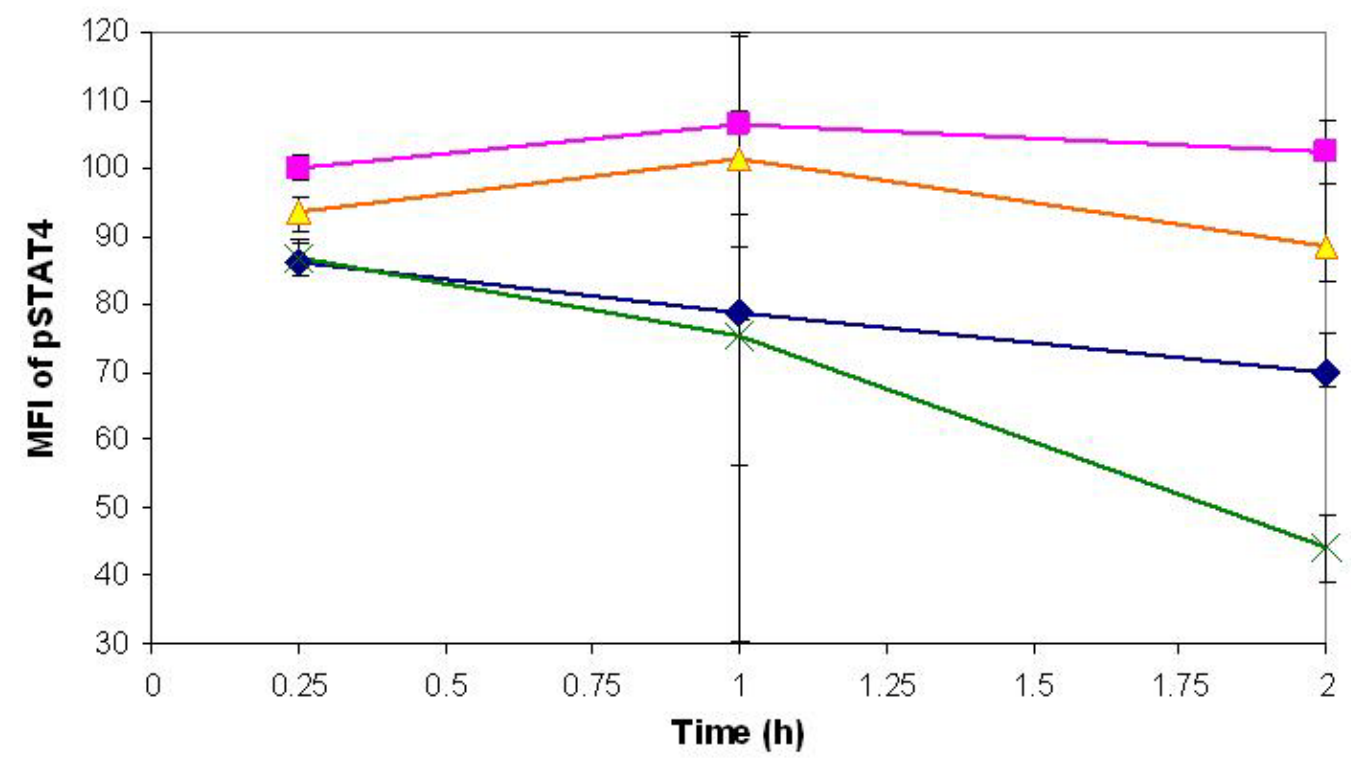

Figure 8. Time course of pSTAT4 expression in different treatment groups with TGF- $\beta$. 2 D6 cell groups plated at a density of $6 \times 10^{4}$ cells/well were stimulated with $10 \mathrm{ng} / \mathrm{ml}$ of TGF$\beta$ (cross marks), $40 \mathrm{ng} / \mathrm{ml}$ of IL-12 (triangles), with both TGF- $\beta$ and IL-12(squares) or left untreated (diamonds), and allowed to remain in culture for 15 minutes, 1 hour and 2 hours. Means of MFI values of pSTAT4 are shown above. 
Table 3. P-values from two-way ANOVA for analysis of TGF- $\beta$ experiments.

STAT4 phosphorylation

Cell viability

\begin{tabular}{|c|c|c|c|c|c|c|}
\hline Time & IL-12 & TGF- $\boldsymbol{\beta}$ & Interaction & IL-12 & TGF- $\boldsymbol{\beta}$ & Interaction \\
\hline 15 min & $<0.001$ & 0.031 & 0.077 & 0.237 & 0.939 & 0.265 \\
\cline { 2 - 7 } 1 hour & 0.136 & 0.262 & 0.605 & 0.758 & 0.014 & 0.12 \\
\cline { 2 - 7 } 2 hours & $<0.001$ & $<0.001$ & $<0.001$ & 0.011 & 0.001 & 0.005 \\
\hline
\end{tabular}

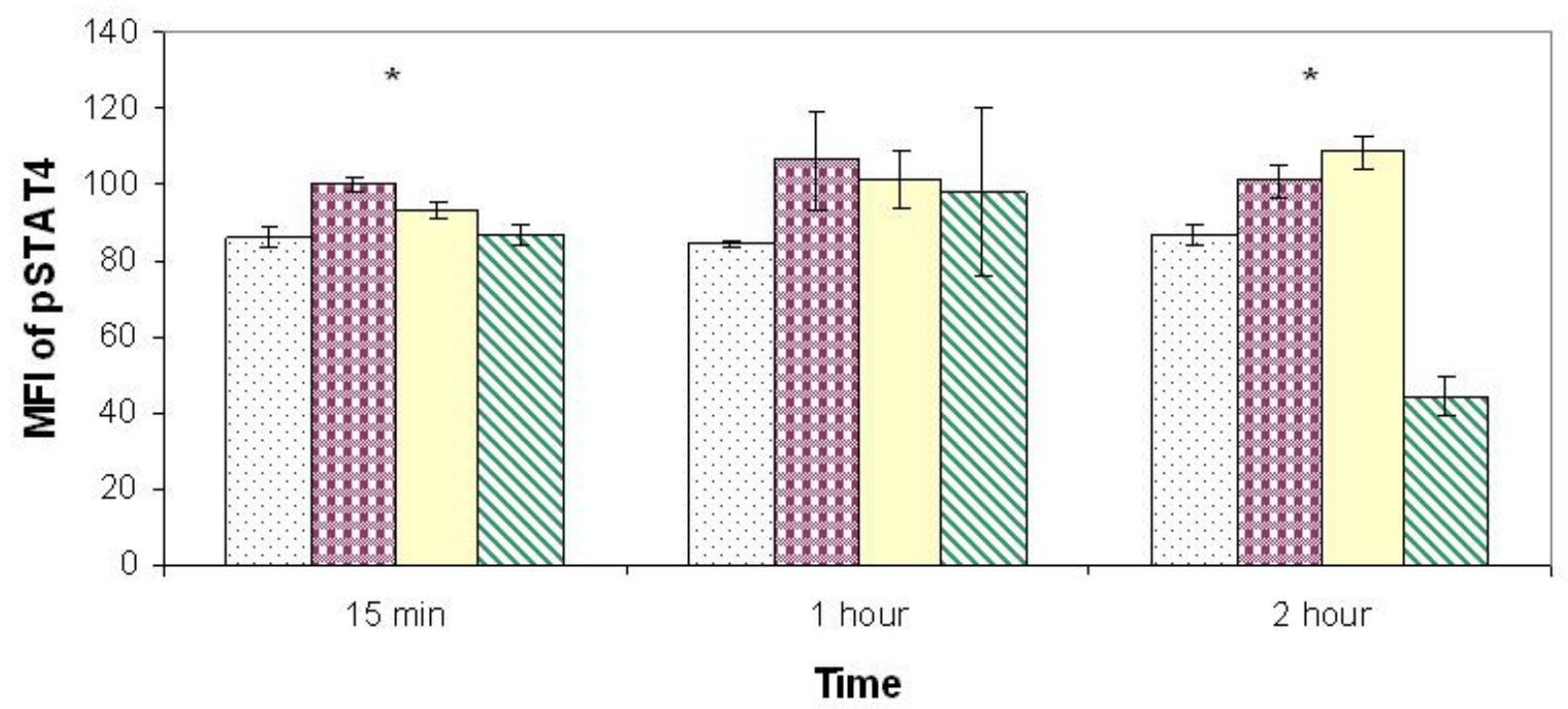

Figure 9. Median fluorescent intensities of pSTAT4 per time point.

The bars represent the MFI values of phosphorylated pSTAT4 at each time point for each of the treatments: cells stimulated with $10 \mathrm{ng} / \mathrm{ml}$ of TGF- $\beta$ (diagonal-line pattern), $40 \mathrm{ng} / \mathrm{ml}$ of IL12 (yellow, no pattern), with both TGF- $\beta$ and IL-12(plaid pattern) or left untreated (dotted pattern), and allowed to remain in culture for the indicated times. Means of MFI values of pSTAT4 are shown above. The asterisks show the time points at which significant differences with respect to the unstimulated group were observed (Table 3).

Effect of TGF- $\beta$ on cell viability

The time course in the viability of the 2D6 treatment groups is depicted in Figure 10. The values of cell viability (i.e. live cell percent) were analyzed for each time point to compare across treatments. In general all treatment groups displayed a subtle decreasing trend in viability with increasing time, except for the untreated 
group where a peak in live cell percent was observed at 1 hour after time 0 (mean= 29.05). The lowest mean value for live cell percent was reached by the group treated with TGF- $\beta$ only after 2 hours (mean=5.27) (Figures 10,11).

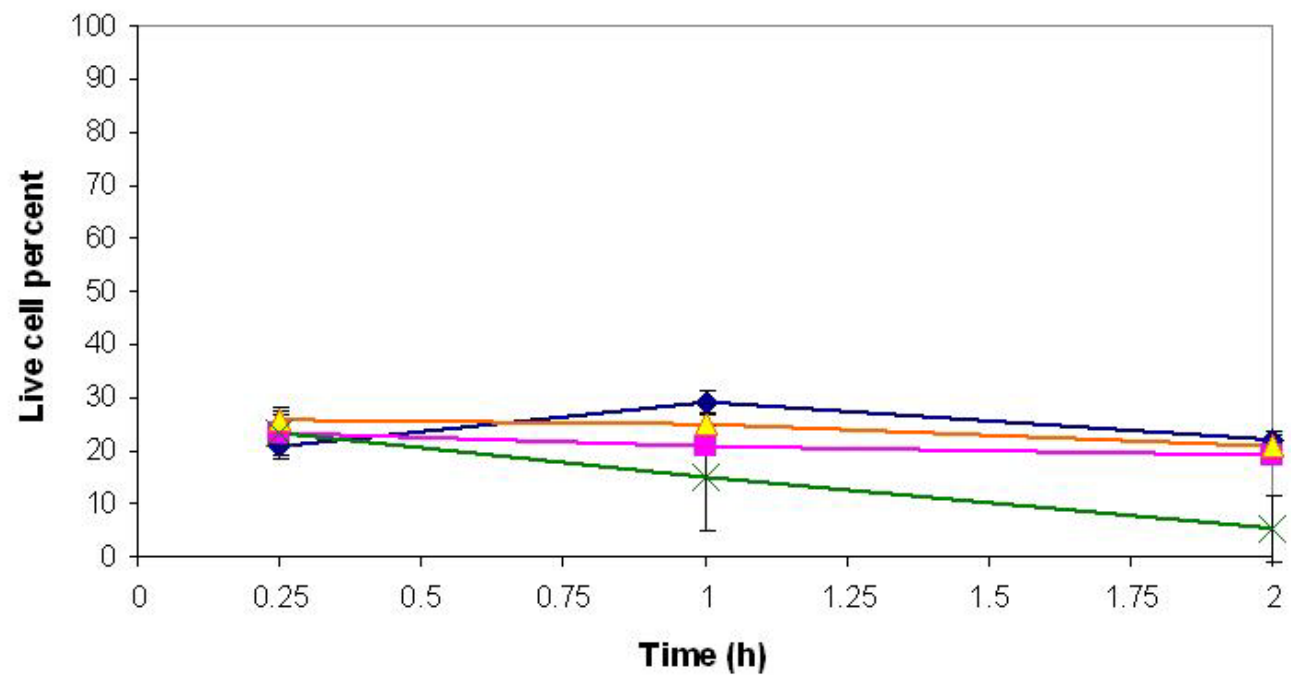

Figure 10. Time course of cell viability in different treatment groups of TGF- $\beta$.

$2 \mathrm{D} 6$ cell groups plated at a density of $6 \times 10^{4}$ cells/well were stimulated with $10 \mathrm{ng} / \mathrm{ml}$ of TGF$\beta$ (cross marks), $40 \mathrm{ng} / \mathrm{ml}$ of IL-12 (triangles), with both TGF- $\beta$ and IL-12(squares) or left untreated (diamonds), and allowed to remain in culture for 15 minutes, 1 hour and 2 hours. Means of live cell percent values are shown above.

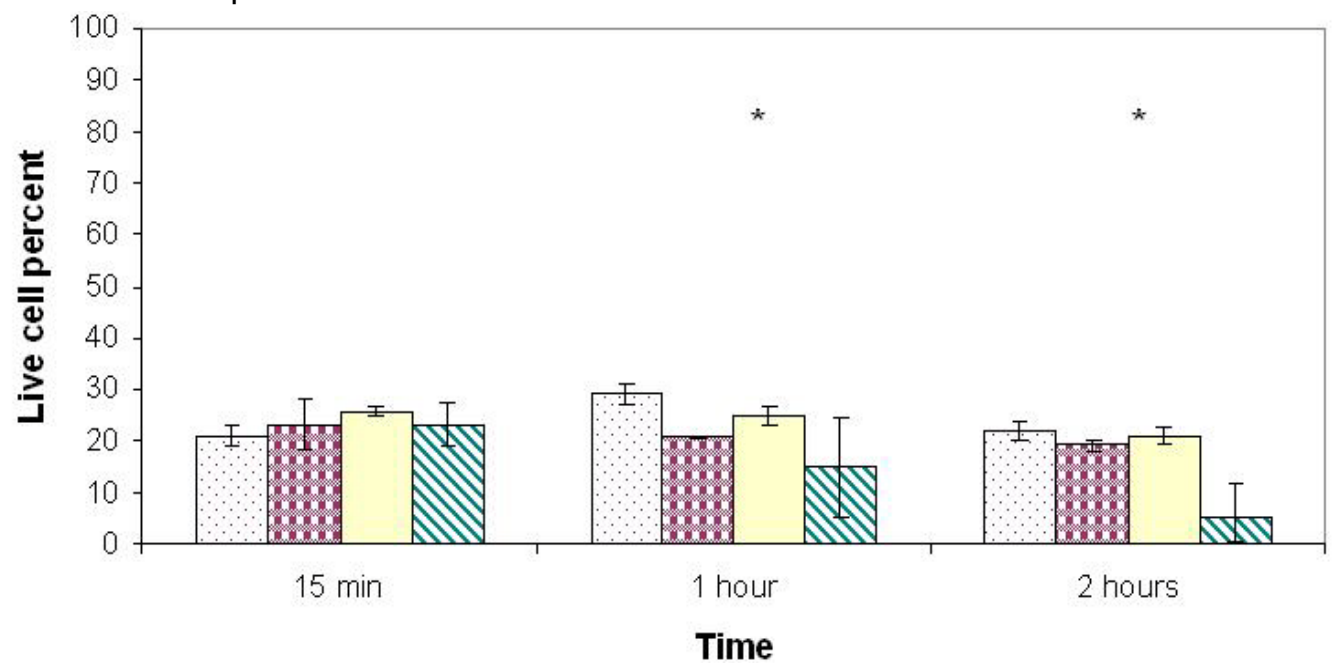

Figure 11. Cell viability per time point.

The bars represent the values of live cell percent at each time point for each of the treatments: cells stimulated with $10 \mathrm{ng} / \mathrm{ml}$ of TGF- $\beta$ (diagonal-line pattern), $40 \mathrm{ng} / \mathrm{ml}$ of IL-12 (yellow, no pattern), with both TGF- $\beta$ and IL-12(plaid pattern) or left untreated (dotted pattern), and allowed to remain in culture for the indicated times. Means of live cell percent values are shown above. The asterisks show the time points at which significant differences with respect to the unstimulated group were observed (Table 3). 


\subsubsection{Discussion}

Transforming growth factor- $\beta$ has been previously shown to inhibit IL-12 signaling (Bright, Sriram 1998, Pardoux et al. 1999). Pardoux et al. observed that treatment with TGF- $\beta$ for 20 minutes inhibited STAT4 phosphorylation significantly in human T-cells, the same Bright and Sriram found in mouse T-cells. However, in the present study the strongest inhibitory effect of TGF- $\beta$ was observed after incubation for 2 hours suggesting that time frame for the effect of this protein on the model cell line used may be longer than in vivo. Other STAT proteins like STAT1 exhibit rapid activation and deactivation kinetics with a half life of approximately 15 minutes(Lim, Cao 2006). The results in this study show that stimulation with IL-12 yields a peak of pSTAT4 after an hour of incubation (Figure 8). This observed delay in the stimulatory effects of IL-12 may be common to other effects in this cell line, or it is possible that TGF- $\beta$ has a delayed onset of action in these cells. However the inhibitory effect was observed only in the cells stimulated with TGF- $\beta$ only, not in the ones stimulated with both TGF- $\beta$ and IL-12, in fact, the highest STAT4 activation was accomplished in the by this group suggesting a synergistic effect of TGF- $\beta$ and IL-12 in the 2D6 cells. Bright and Sriram conducted a study on the effect of TGF- $\beta$ on murine T-cells, and found that it inhibited the activity of Janus kinase-2 (JaK-2) and Tyrosine kinase-2 (Tyk-2) to a great extent, causing the inhibition of STAT4 phosphorylation as well (Bright, Sriram 1998). However, Sudarshan et al found that TGF- $\beta$ had no effect on the activation of JaK-2 and Tyk-2, and did not inhibit STAT4 phosphorylation by these kinases (Sudarshan et al. 1999). The TGF- $\beta$ ligand starts signaling by bringing 
together type I and type II receptor serine/threonine kinases as it binds them at the surface of the T-cell. Receptor II phosphorylates the kinase domain in receptor I and the activated receptor subsequently phosphorylates Smad proteins (Shi, Massague 2003). Active STAT4 promotes the expression of Smad7, a regulatory protein that antagonizes TGF- $\beta$ signaling (Letterio 2005, Soto, Price-Schiavi \& Carraway 2003). This would explain the observed synergy between IL-12 and TGF- $\beta$. An increase on Smad 7 in 2D6 cells upon stimulation with IL-12 would support the hypothesis.

Another interesting effect observed after incubation with TGF- $\beta$ was the increased reduction of cell viability after 2 hours of incubation with TGF- $\beta$ only (Figure 9). TGF- $\beta$ has been linked to apoptosis in several studies. The mechanism of action includes the expression of cyclin-dependent kinases (CDKs) that inactivate proteins important for cell survival, and the expression of death-associated protein (DAP) kinase (Jang et al. 2002). The increased variability in the effects after 2 hours of TGF- $\beta$ alone (Figure 9 and Appendix C) on both STAT4 activation and viability may be a result of the extensive amount of cross-talk that takes place in TGF- $\beta$ signaling once it reaches the level of Smads (Massague 2000). This cross-talk is additionally enhanced by the cooperative actions of Smads in the nucleus for the transcription of several target genes that are transcribed depending on the cell type and its metabolic needs (Jang et al. 2002). Observing changes in associated signaling proteins may help inform on the mechanisms that TGF- $\beta$ uses to promote apoptosis. 


\subsubsection{Effect of insulin on STAT4 phosphorylation}

The time course in the expression of pSTAT4 in 2D6 cells upon stimulation with insulin is shown in Figure 12. The MFI values of STAT4 phosphorylation were analyzed for each time point to compare across treatments (see Appendix C), Significant differences with respect to the unstimulated group were observed mainly due to IL-12 stimulation at all time points (Table 4). Insulin only had a significant effect on 2D6 cell after 1 hour of treatment and in the presence of IL-12, while the cell group stimulated with insulin only displayed a very similar trend to the unstimulated group maintaining close MFI values through the 2 hours. The highest MFI value for STAT4 activation was observed after 1 hour of incubation in the group treated with IL12 and insulin (mean=94.9) (Figure 13).

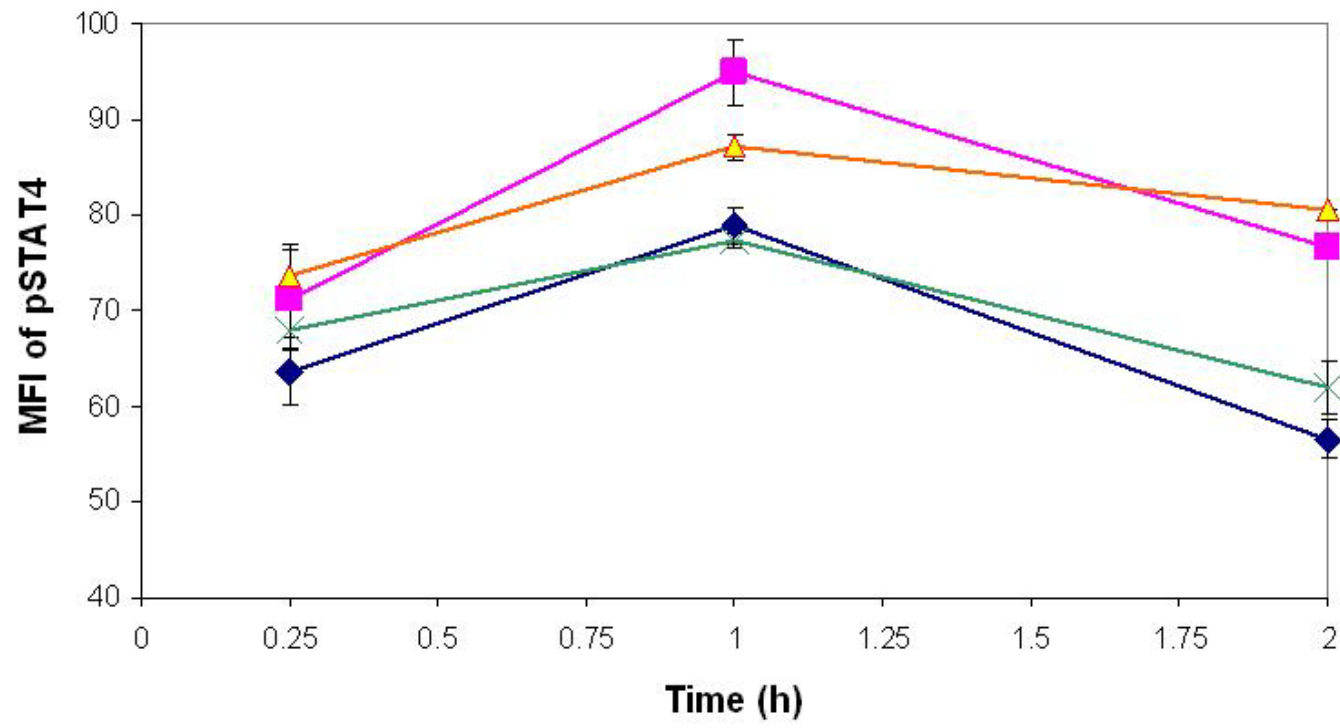

Figure 12. Time course of PSTAT4 expression in different treatment groups with insulin 2D6 cell groups plated at a density of $6 \times 10^{4}$ cells/well were stimulated with $10 \mathrm{ng} / \mathrm{ml}$ of insulin (cross marks), $40 \mathrm{ng} / \mathrm{ml}$ of IL-12 (triangles), with both insulin and IL-12(squares) or left untreated (diamonds), and allowed to remain in culture for 15 minutes, 1 hour and 2 hours. Means of MFI values of pSTAT4 are shown above. 
Table 4. P-values from two-way ANOVA for analysis of insulin experiments.

STAT4 phosphorylation

Cell viability

\begin{tabular}{|c|c|c|c|c|c|c|}
\hline Time & IL-12 & Insulin & Interaction & IL-12 & Insulin & Interaction \\
\hline \multirow{2}{*}{$\begin{array}{c}15 \text { min } \\
1 \text { hour }\end{array}$} & 0.016 & 0.694 & 0.141 & 0.311 & 0.995 & 0.379 \\
\cline { 2 - 7 } 2 hours & $<0.001$ & 0.033 & 0.005 & 0.197 & 0.043 & 0.606 \\
\cline { 2 - 7 } & $<0.001$ & 0.484 & 0.002 & 0.106 & 0.374 & 0.048 \\
\hline
\end{tabular}

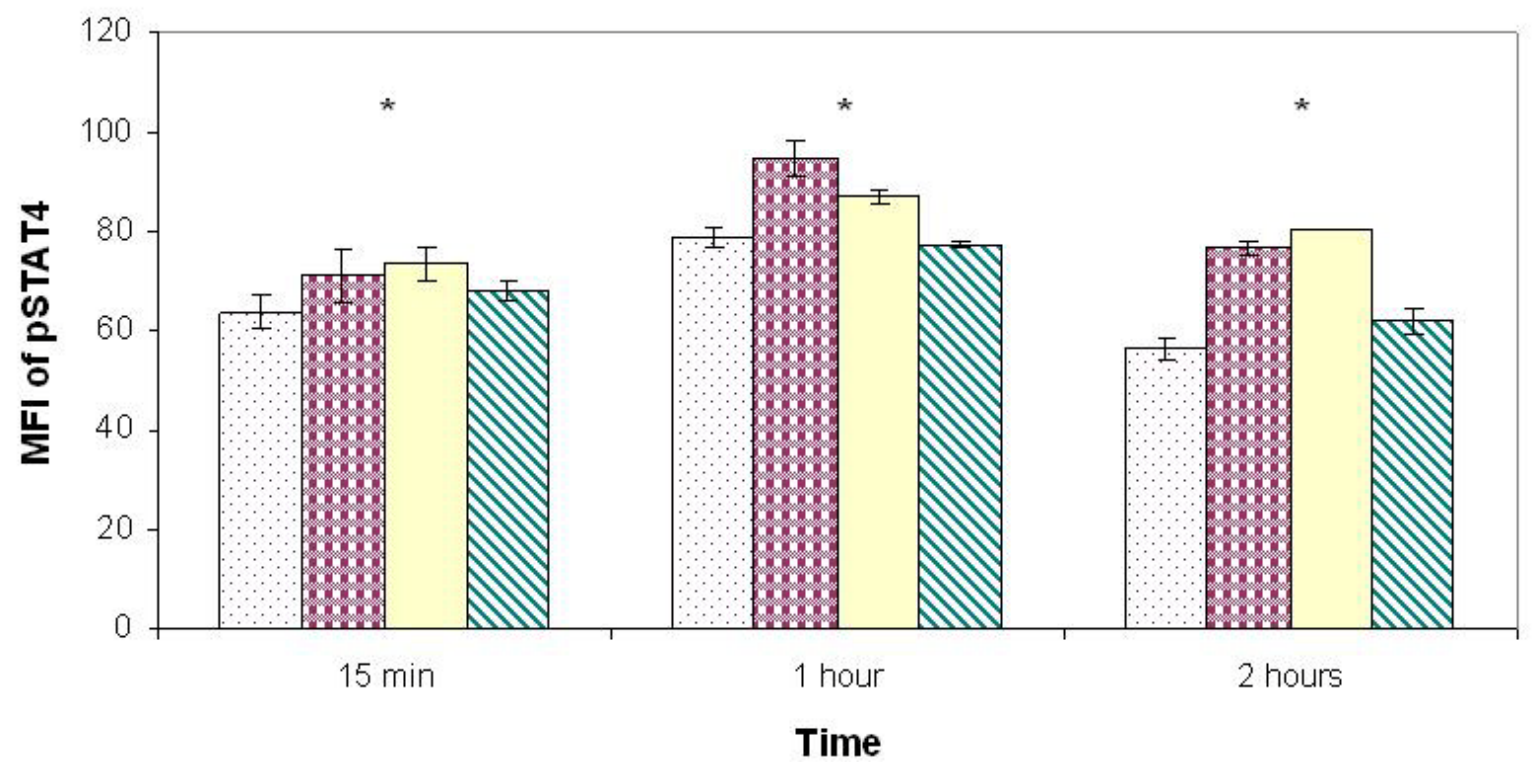

Figure 13. Median fluorescent intensities of PSTAT4 per time point.

The bars represent the MFI values of phosphorylated PSTAT4 at each time point for each of the treatments: cells stimulated with $10 \mathrm{ng} / \mathrm{ml}$ of insulin (diagonal-line pattern), $40 \mathrm{ng} / \mathrm{ml}$ of IL12 (yellow, no pattern), with both insulin and IL-12(plaid pattern) or left untreated (dotted pattern), and allowed to remain in culture for the indicated times. Means of MFI values of PSTAT4 are shown above. The asterisks show the time points at which significant differences with respect to the unstimulated group were observed (Table 4).

Effect of insulin on cell viability

All treatment groups exhibited a subtle increase in viability at 1 hour followed by a decrease except for the untreated group where the live cell percent continued to increase in time(Figures 14, 15). The highest percent of live cells was observed at 1 hour in the group treated with both insulin and IL-12 (mean=33.62). In general treatments no effect on cell viability, except for the group treated with insulin where 
statistically significant difference with respect to the unstimulated group was observed (Table 4).

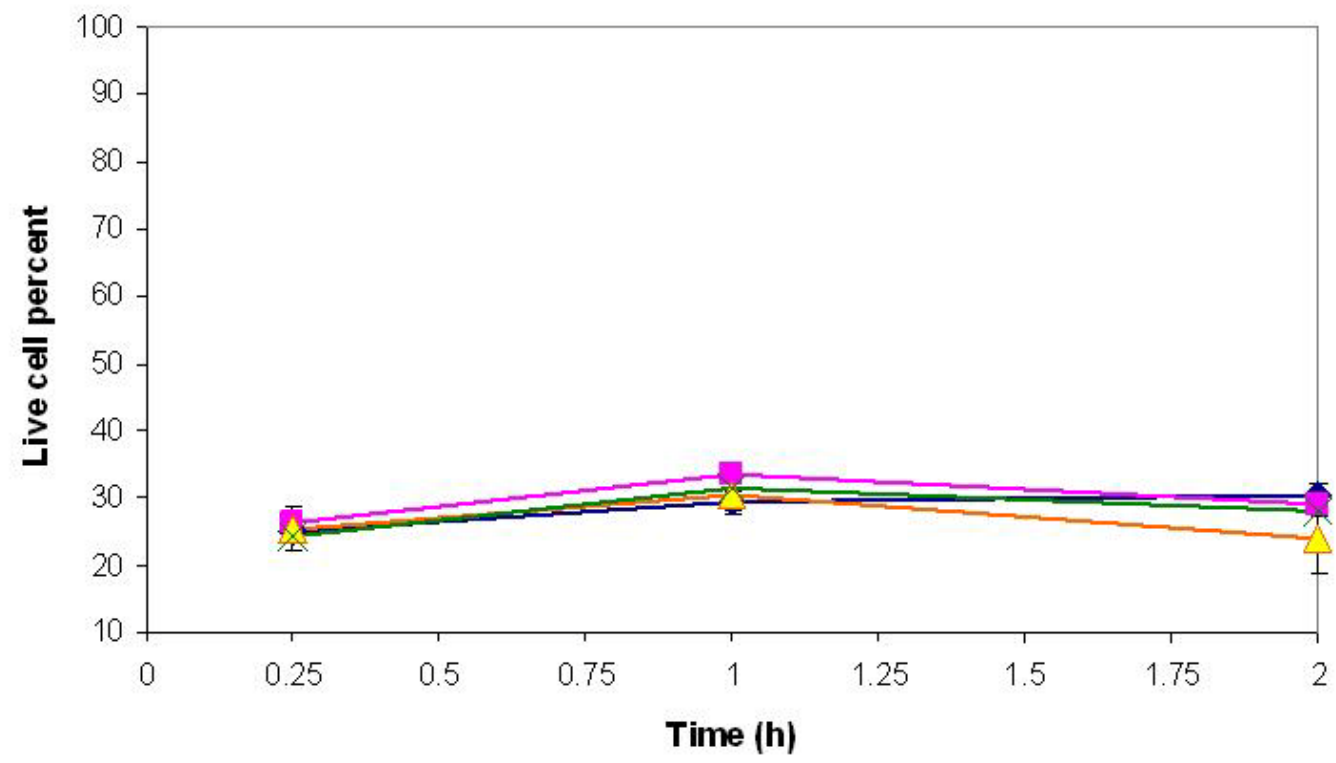

Figure 14. Time course of cell viability in different treatment groups of insulin

2D6 cell groups plated at a density of $6 \times 10^{4}$ cells/well were stimulated with $10 \mathrm{ng} / \mathrm{ml}$ of insulin (cross marks), $40 \mathrm{ng} / \mathrm{ml}$ of IL-12 (triangles), with both insulin and IL-12(squares) or left untreated (diamonds), and allowed to remain in culture for 15 minutes, 1 hour and 2 hours. Means of live cell percent values are shown above.

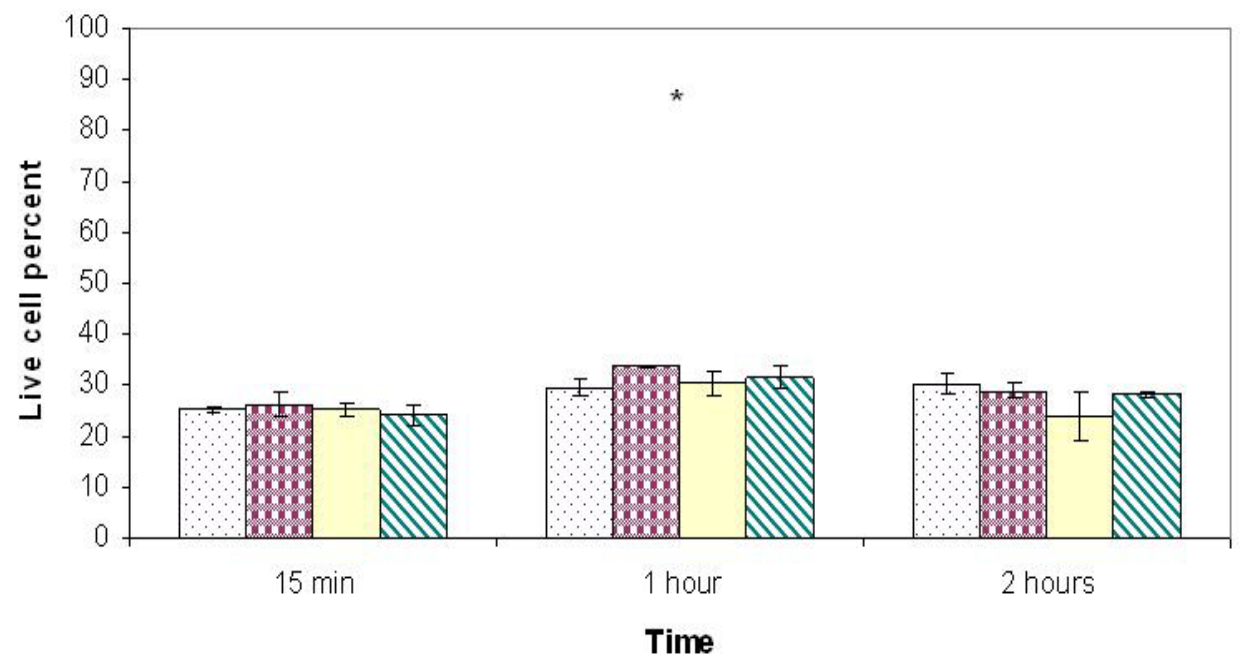

Figure 15. Cell viability per time point.

The bars represent the values of live cell percent at each time point for each of the treatments: cells stimulated with $10 \mathrm{ng} / \mathrm{ml}$ of insulin (diagonal-line pattern), $40 \mathrm{ng} / \mathrm{ml}$ of IL-12 (yellow, no pattern), with both insulin and IL-12(plaid pattern) or left untreated (dotted pattern), and allowed to remain in culture for the indicated times. Means of live cell percent values are shown above. The asterisks show the time points at which significant differences with respect to the unstimulated group were observed (Table 4). 


\subsubsection{Discussion}

In the present study the relationship between stimulation with insulin and IL-12 signaling in the Th1 cell line, 2D6, was shown for the first time. Viardot et al. found that insulin promoted Th2 differentiation by reducing the IFN-Y (i.e. cytokine produced by Th1 cells) to IL-4 (i.e. cytokine produced by Th2 cells) ratio in vitro in human peripheral blood mononuclear cells (PBMC)(Viardot et al. 2007). These findings coincide with a reduction in STAT4 phosphorylation in the 2D6 cell line after incubating with insulin only for 1 and 2 hours. However, the fact that an up-regulating effect in STAT4 phosphorylation was observed in the present study after 15 minutes and 1 hour of incubation, it is possible that insulin participates in a pathway that cooperates synergistically with IL-12 to activate STAT4. However, considering the activation of STAT4 peaks at 1 hour across treatment groups and then decreases and that in Viardot's study the cells were treated for 72 hours, it is possible that a more pronounced effect may be observed with the 2D6 cells in culture with insulin within a larger time frame.

A similar increasing trend peaking at 1 hour was observed for the cell viability. Although to a subtle extent, the increased viability is in agreement with Viardot's observations of insulin inhibiting apoptosis in CD4+ T-cells (Viardot et al. 2007). This is also consistent with another study on cells from a murine T-cell line, A1.1, where up-regulated levels of IRS-1 correlated with an inhibition of apoptotic signaling events due to activation-induced cell death (AICD) (Li et al. 2002)and with the inhibition of 
apoptosis observed in vascular smooth muscle cells(Allen et al. 2005). In general, future experiments increasing the exposure time are recommended to observe the effects of insulin over a larger time frame.

\subsubsection{Effect of IL-6 on STAT4 phosphorylation}

Based on knowledge about the degree of homology between STAT3 and STAT4 the 2D6 cell line was also used to identify signaling cross-talk between IL-12 and IL6. (Levy, Darnell Jr. 2002); (Zhong, Wen \& Darnell 1994)Phosphorylation of STAT4 was used as an indication of IL-12 activation while PSTAT3 was used as a positive control for IL-6 activation. Unfortunately no pSTAT3 was observed in response to IL-6 stimulation (data not shown). In general there was no significant effect of IL-6 on the 2D6 cells at any time point, and the only significant differences with respect to the unstimulated group were due to treatment with IL-12 after 1 and 2 hours of incubation(Table 5) (Figures 16, 17). There was no significant effect of IL-12 or IL-6 on viability in these experiments (Table 5). 


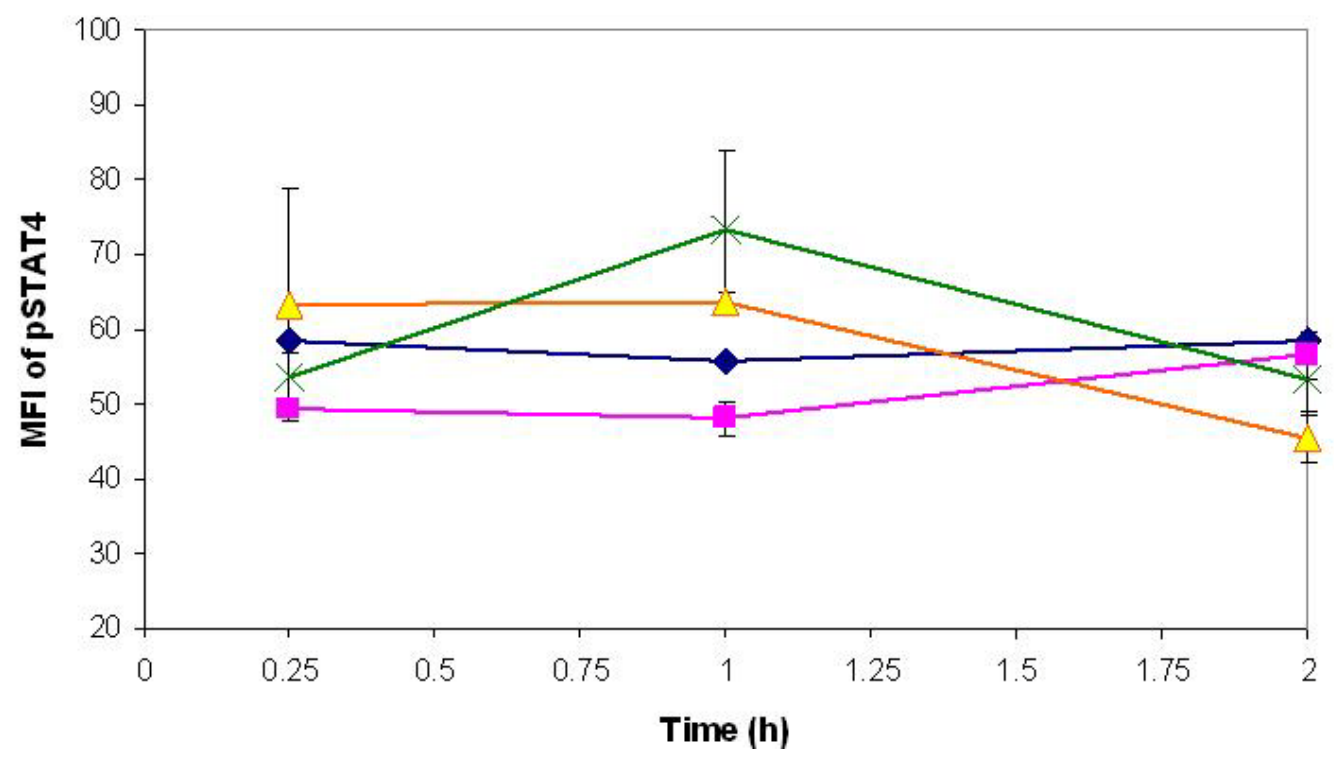

Figure 16. Time course of PSTAT4 expression in different treatment groups with insulin.

2D6 cell groups plated at a density of $6 \times 10^{4}$ cells/well were stimulated with $10 \mathrm{ng} / \mathrm{ml}$ of insulin (cross marks), $40 \mathrm{ng} / \mathrm{ml}$ of IL-12 (triangles), with both insulin and IL-12(squares) or left untreated (diamonds), and allowed to remain in culture for 15 minutes, 1 hour and 2 hours. Means of MFI values of PSTAT4 are shown above.

Table 5. P-values from two-way ANOVA for analysis of IL-6 experiments.

\begin{tabular}{|c|c|c|c|c|c|c|}
\multicolumn{4}{|c}{ STAT4 phosphorylation } & \multicolumn{3}{c|}{ Cell viability } \\
\hline Time & IL-12 & IL-6 & Interaction & IL-12 & IL-6 & Interaction \\
\hline \multirow{2}{1}{$\begin{array}{c}15 \text { min } \\
1 \text { hour }\end{array}$} & 0.946 & 0.075 & 0.364 & 0.994 & 0.798 & 0.477 \\
\cline { 2 - 7 } 2 hours & 0.027 & 0.794 & 0.001 & 0.103 & 0.092 & 0.195 \\
\cline { 2 - 7 } & 0.035 & 0.167 & 0.003 & 0.423 & 0.21 & 0.129 \\
\hline
\end{tabular}




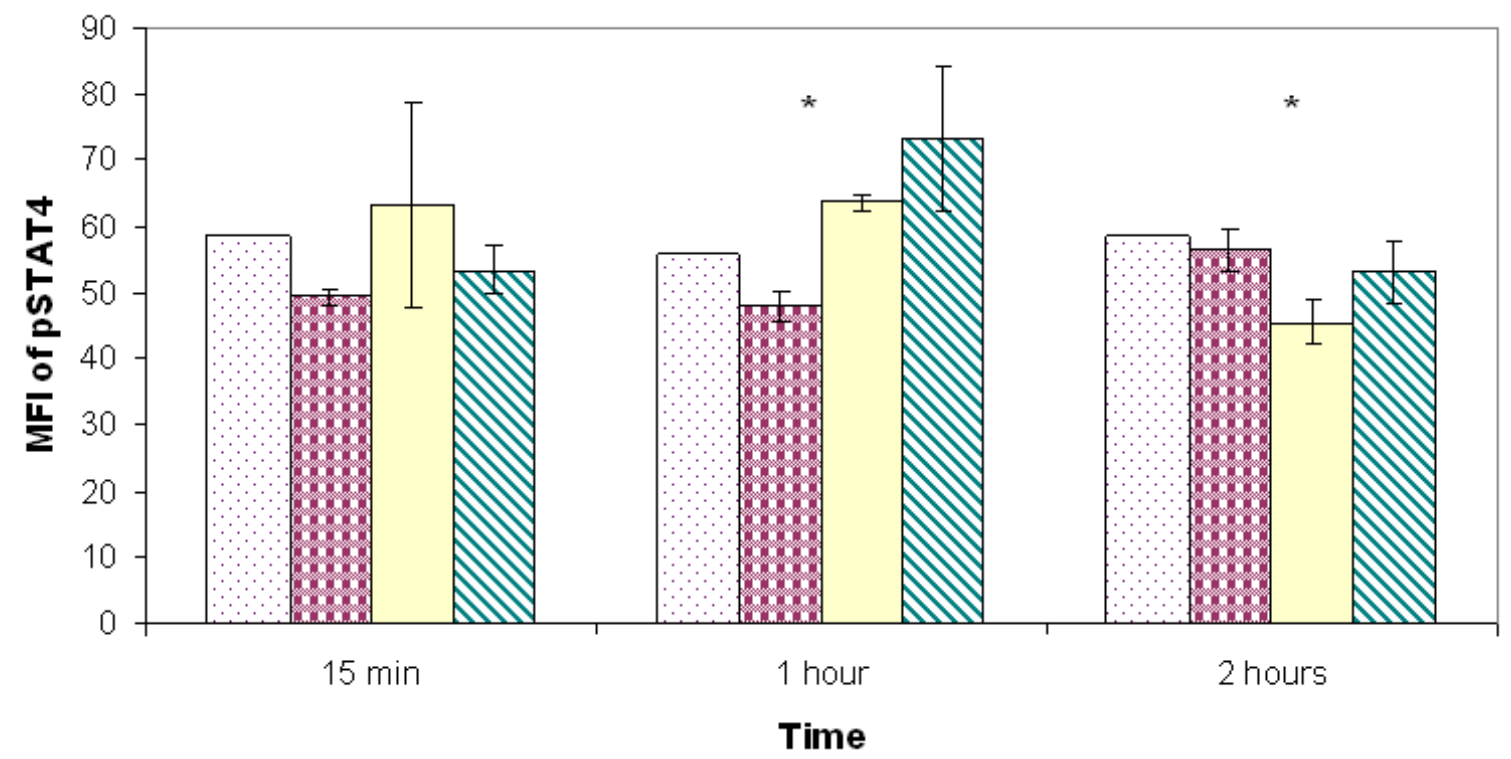

Figure 17. Median fluorescent intensities of pSTAT4 per time point.

The bars represent the MFI values of phosphorylated PSTAT4 at each time point for each of the treatments: cells stimulated with $10 \mathrm{ng} / \mathrm{ml}$ of IL-6 (diagonal-line pattern), $40 \mathrm{ng} / \mathrm{ml}$ of IL-12 (yellow, no pattern), with both IL-6 and IL-12(plaid pattern) or left untreated (dotted pattern), and allowed to remain in culture for the indicated times. Means of MFI values of pSTAT4 are shown above. The asterisks show the time points at which significant differences with respect to the unstimulated group were observed (Table 5).

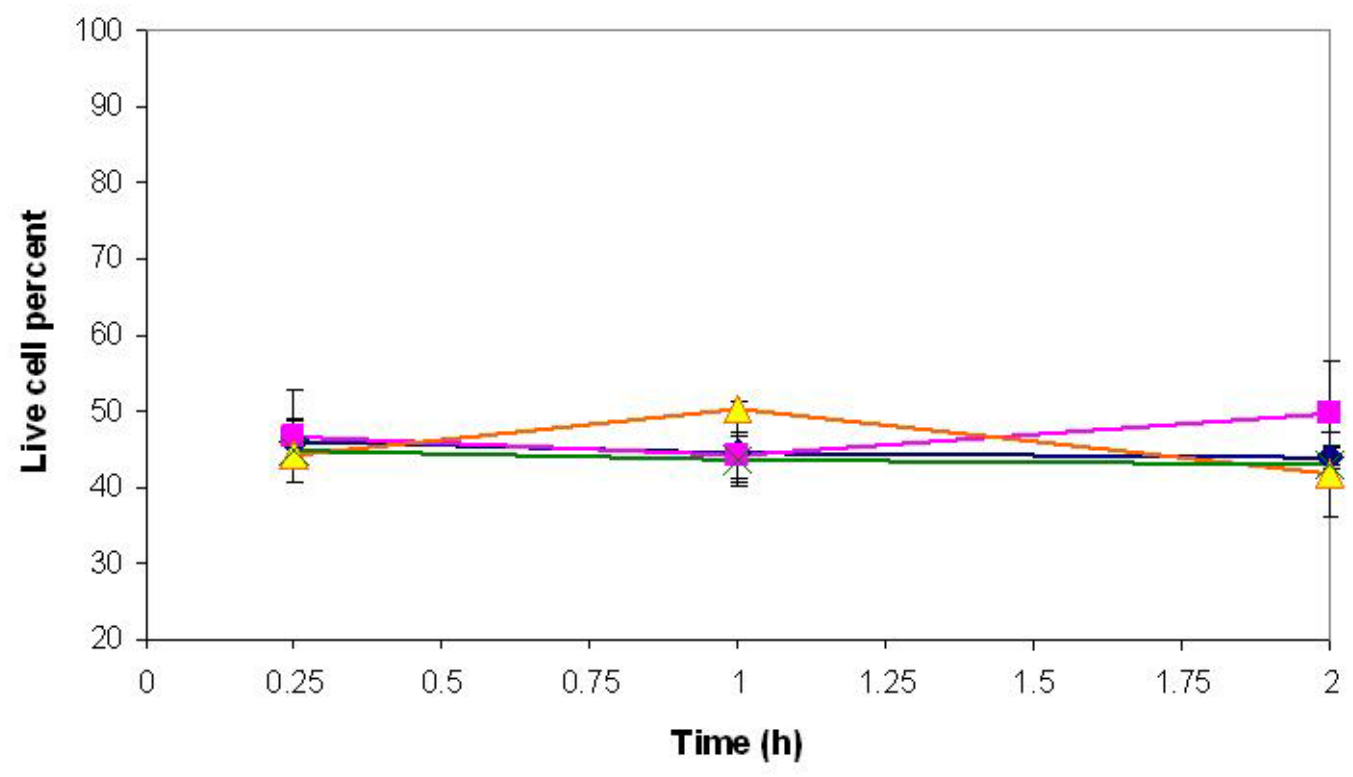

Figure 18. Time course of cell viability in different treatment groups of IL-6.

2D6 cell groups plated at a density of $6 \times 10^{4}$ cells/well were stimulated with $10 \mathrm{ng} / \mathrm{ml}$ of IL-6 (cross marks), $40 \mathrm{ng} / \mathrm{ml}$ of IL-12 ( triangles), with both IL-6 and IL-12(squares) or left untreated (diamonds), and allowed to remain in culture for 15 minutes, 1 hour and 2 hours. Means of live cell percent values are shown above. 


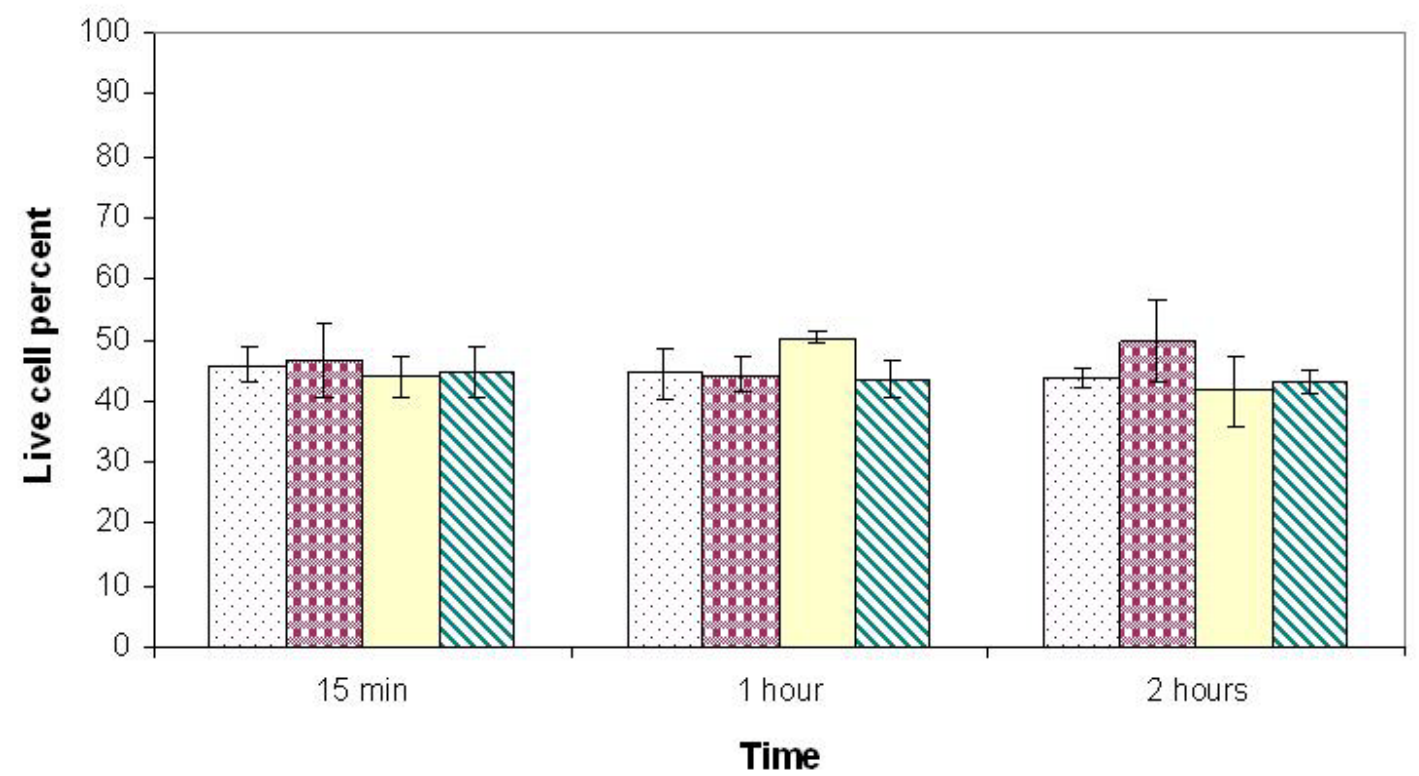

Figure 19. Cell viability per time point.

The bars represent the values of live cell percent at each time point for each of the treatments: cells stimulated with $10 \mathrm{ng} / \mathrm{ml}$ of IL-6 (diagonal-line pattern), $40 \mathrm{ng} / \mathrm{ml}$ of IL-12 (yellow, no pattern), with both IL-6 and IL-12(plaid pattern) or left untreated (dotted pattern), and allowed to remain in culture for the indicated times. Means of live cell percent values are shown above. The asterisks show the time points at which significant differences with respect to the unstimulated group were observed (Table 4).

\subsubsection{Discussion}

The lack of observed pSTAT3 in the experiments in this study lead to a first conclusion about the phosphorylation of STAT3: based on the degree of homology of STAT3 and STAT4 it was possible that all the phosphorylated STAT3 was being bound by the pSTAT4 antibody. This together with the fact that inhibiting effects of IL6 in the present study appear to be more subtle than expected, lead to ask the question of whether STAT3 was being activated upon stimulation with IL-6 or not. Western Blot experiments performed as indicated (See Appendix D) were conducted to observe the phosphorylated STAT3 in the 2D6 cells after treatment with IL-6 and/or 
IL-12 (Figure 17). The fact that no phosphorylated STAT3 was observed after the Western Blot experiments suggested that STAT3 was not being activated at all by IL6 in these cells. Ahn et al (Ahn et al. 1998)observed phosphorylated STAT3 in 2D6 cells upon stimulation with IL-12; however, considering the responsiveness of the cell line to this interleukin, it is possible that the STAT3 observed was STAT4 that was bound non-specifically. A possible explanation could be that pSTAT3 is being deactivated before detection by cross-talk with an inhibiting pathway or could be all activated by IL-12 prior to the experiment.

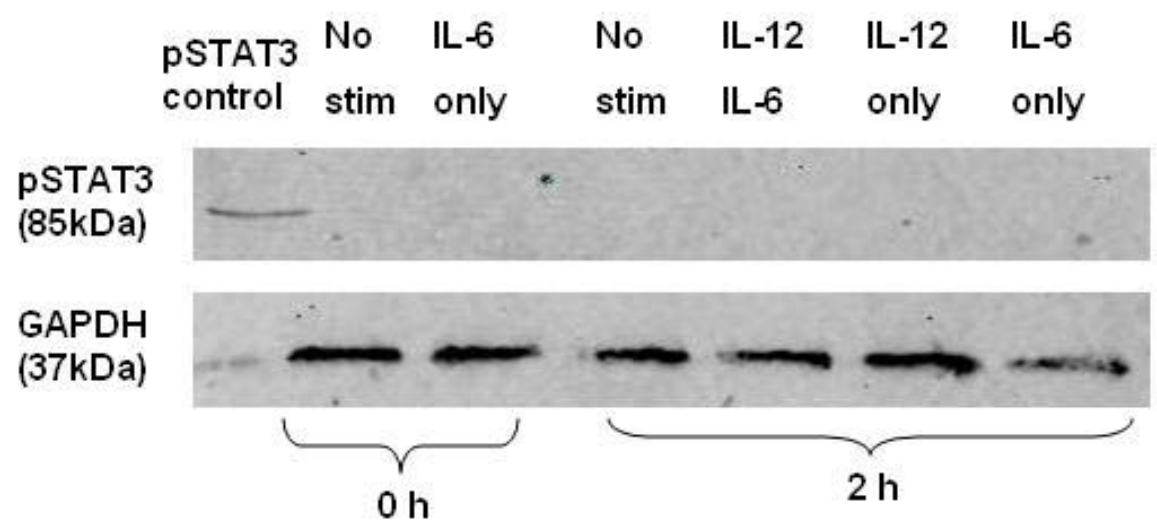

Figure 20. Western blot to observe pSTAT3 in 2D6 cells upon treatment with IL-6.

Cells were treated as they were for the previous experiments (see Materials and Methods) and lysed for protein separation by gel electrophoresis. The gel was blotted onto a membrane that was probed with antibodies against phosphorylated STAT3 (See Appendix D).

Sengupta et al. found that in human myeloid cells the phosphorylation of STAT3 was inhibited within 5 minutes upon IL- 6 stimulation by the action of MEK and ERK kinases that act by blocking the signaling pathway upstream of STAT3 activation (Sengupta et al. 1998). It is possible that the MEK-ERK signaling pathway is being activated and is inhibiting phosphorylation of STAT3 as an early event during the 
incubation time.

The IL-6 receptor is composed of a ligand-binding a-chain and the signal transducer gp130 that contains six tyrosines in its cytoplasmic region, among which Tyr 759 is required for activation via STAT3 of SOCS3, which is STAT proteins' competitor for binding the IL-12 receptor and for phosphorylation by Jak-2(Yamamoto et al. 2003, Nishihara et al. 2007). It is also possible that the 2D6 cell line does not express the IL-6 receptor on its surface, rendering the cell unresponsive to IL-6 mediated signal for activation. In recent unpublished work in our research group it was found that these cells do not respond to stimulation with IFN-Y (data not shown), so perhaps they do not respond to IL-6 either. Verification of the presence of the IL-6 receptor, namely the g130 signal transducer on the surface of 2D6 Th1 cells should provide more insight into the lack of an observed effect of IL-6 on these cells.

\subsection{Conclusion}

The assay allowed the observation of a significant inhibition exerted by TGF- $\beta$ on 2D6 cells. Subtle effects were observed when the cell groups were incubated with insulin, however the cross-talk between insulin and IL-12 signaling remains unclear. It is necessary to observe the effects on more proteins downstream the receptor (e.g. IRS-1) to understand the phenomenon. In addition longer incubation times may allow the observation of a more significant effect.

Regarding cross-talk between IL-6 and IL-12, It is possible that the 2D6 cell line does not respond to IL-6 due to a lack of receptor expression. Either using more than one cell model or a different one, or studying the effect on other molecules 
downstream of inhibitor-binding to cell surface is recommended for future experiments.

In general the assay designed was able to provide with answers about inhibitiory effects of the factors studied on IL-12 signaling despite a relatively restricted time frame. However, more questions need to be answered to fully understand the effect of each factor. 


\section{REFERENCES}

Ahn, H., Tomura, M., Yu, W., Iwasaki, M., Park, W., Hamaoka, T. \& Fujiwara, H. 1998, "Requirement for distinct Janus kinases and STAT proteins in T cell proliferation versus IFN-gamma production following IL-12 stimulation", Journal of Immunology, vol. 161, pp. 5893-5900.

Aljurf, M., Ezzat, A. \& Mussa M., O. 2002, "Emerging role of gammadelta T-cells in health and disease", Blood Reviews, vol. 16, pp. 203-206.

Allen, R.T., Krueger, K.D., Dhume, A. \& Agrawal, D.K. 2005, "Sustained Akt/PKB activation and transient attenuation of c-Jun $\mathrm{N}$-terminal kinase in the inhibition of apoptosis by IGF-1 in vascular smooth muscle cells", Apoptosis, vol. 10, pp. 525-535.

Becker, C., Pohla, H., Frankenberger, B., Schuler, T., Assenmacher, M., Schendel, D.J. \& Blankenstein, T. 2001, "Adaptive tumor therapy with T lymphocytes enriched through an IFN- $y$ capture assay", Nature Medicine, vol. 7, no. 10, pp. 1159-1162.

Ben-Baruch, A. 2003, "Inflammatory cells,cytokines and chemokines in breast cancer progression:reciprocal tumor microenvironment interactions", Breast Cancer Research, vol. 5, pp. 31-36.

Bobryshev, Y.V. 2000, "Dendritic cells and their involvement in atherosclerosis", Current Opinion in Lipidology, vol. 11, pp. 511-517.

Bright, J.J. \& Sriram, S. 1998, "TGF- $\beta$ inhibits IL-12-induced activation of Jak-STAT pathway in T lymphocytes", Journal of Immunology, vol. 161, pp. 1772-1777.

Burdelya, L., Catlett-Falcone, R., Levitzki, A., Cheng, F., Coppola, D., Sun, J., Sebti, S., Dalton, W.S., Jove, R. \& Yu, H. 2002, "Combination therapy with AG-490 and interleukin 12 achieves greater antitumor effects than either agent alone", Molecular Cancer Therapeutics, vol. 1, pp. 893-899.

Cancro, M.P., Hao, Y., Scholz, J.L., Riley, R.L., Frasca, D., Dunn-Walters, D.K. \& Blomberg, B.B. 2009, "B cells and aging:molecules and mechanisms", Trends in Immunology, vol. 30, no. 7, pp. 313-318. 
Chien, Y.-. \& Boneville, M. 2006, "Gamma delta T cell receptors", Cellular and Molecular Life Sciences, vol. 63, pp. 2089-2094.

Cooper, M.D. \& Alder, M.N. 2006, "The evolution of adaptive immune systems", Cell, vol. 124, pp. 815-822.

Cua, D.J. \& Tato, C.M. 2010, "Innate IL-17-producing cells:", Nature Reviews, vol. 10, pp. 479-489.

Davis, M.M., Krogsgaard, M., Huppa, J.B., Sumen, C., Purbhoo, M.A., Irvine, D.J., Wu, L.C. \& Ehrlich, L. 2003, "Dynamics of cell surface molecules during T cell recognition", Annual Review of Biochemistry, vol. 72, pp. 717-742.

Desbois-Mouthon, C., Blivet-Van Eggelpoel, M., Auclair, M., Cherqui, G., Capeau, J. \& Caron, M. 1998, "Insulin diferentially regulates SAPNKs/JNKs and ERKs in CHO cells overexpressing human insulin receptors", Biochemical and Biophysical Research Communications, vol. 243, pp. 765-770.

Dong, C., Davis, R.J. \& Flavell, R.A. 2002, "MAP kinases in the immune response", Annual Review of Immunology, vol. 20, pp. 55-72.

Ebner, S., Ratzinger, G., Krosbacher, B., Schmuth, M., Weiss, A., Reider, D., Kroczek, R.A., Herold, M., Heufler, C., Fritsch, P. \& Romani, N. 2001, "Production of IL-12 by human monocyte-derived dendritic cells is optimal when the stimulus is given at the onset of maturation, and is further enhanced by IL-4", The Journal of Immunology, , pp. 633-641.

Eddhari, F., Denanglaire, S., Bureau, F., Spolski, R., Leonard, W.J., Leo, O. \& Andris, F. 2009, "Interleukin 6/STAT3 signaling regulates the ability of naive T cells to acquire B-cell help capacities", Blood, vol. 113 , no. 11, pp. 2426-2433.

Finley, S.D., Gupta, D., Cheng, N. \& Klinke II, D.J. 2010, "Inferring relevant control mechanisms for interleukin-12 signaling in naive CD4+ T cells", Immunology and Cell Biology, , pp. 1-11.

Flavell, R.A., Sanjabi, S., Wrzesinsky, S.H. \& Licona-Limon, P. 2010, "The polarization of immune cell in the tumour environment by TGF $\beta$ ", Nature Reviews, vol. 10, pp. 554-567.

Frassanito, M.A., Cusmai, A., lodice, G. \& Dammacco, F. 2001, "Autocrine interleukin-6 production and highly malignant multiple 
myeloma:relation with resistance to drug-induced apoptosis", Blood, vol. 97, no. 2, pp. 483-489.

Galli, G., Nuti, S., Tavarini, S., Galli-Stampino, L., De Lalla, C., Cassorati, G., Dellabona, P. \& Abrignani, S. 2003, "CD1d-restricted help to B cells by human invariant natural killer T lymphocytes", Journal of Experimental Medicine, vol. 197, pp. 1051-1057.

Galli, S.J., Gordon, J.R. \& Wershil, B.K. 1991, "Cytokine production by mast cells and eosinophils", Current opinion in Immunology, vol. 3, pp. 865-870.

Gerloni, M., Rizzi, M., Castiglioni, P. \& Zanetti, M. 2004, "T cell immunity using transgenic B lymphocytes", Proceedings of the National Academy of Sciences, vol. 101, no. 11, pp. 3892-3897.

Hanafusa, H., Ninomiya-Tsuji, J., Masuhama, N., Nishita, M., Fujisawa, J., Shibuya, H., Matsumoto, K. \& Nishida, E. 1999, "Involvement of the p38-mitogen-activated protein kinase pathway in transforming growth factor- $\beta$-induced gene expression", Journal of Biological Chemistry, vol. 274, no. 38, pp. 27161-27167.

Heath, W.R. \& Carbone, F.R. 2009, "Dendritic cell subsets in primary and secondary T cell responses at body surfaces", Nature Immunology, vol. 10, no. 12, pp. 1237-1244.

Herberman, R.B., Nunn, M.E. \& Lavrin, D.H. 1975, "Natural cytotoxic reactivity of mouse lymphoid cells against syngeneic acid allogeneic tumors", International Journal of Cancer, vol. 16, pp. 216229.

Iwasaki, A. \& Medzhitov, R. 2004, "Toll-like receptor control of the adaptive immune responses", Nature Immunology, vol. 5, pp. 987995.

Izzi, L. \& Attisano, L. 2004, "Regulation of the TGF- $\beta$-signaling pathway by ubiquitin-mediated degradation", Oncogene, vol. 3, pp. 20702078.

Jang, C., Chen, C., Chen, C., Chen, J., Su, Y. \& Chen, R. 2002, "TGF- $\beta$ induces apoptosis through Smad-mediated expression of DAPkinase", Nature Cell Biology, vol. 4, pp. 51-58. 
Kawai, T. \& Akira, S. 2010, "The role of pattern recognition receptors in immunity:update on Toll-like receptors", Nature Immunology, vol. 11, no. 5, pp. 373-384.

Klinke II, D.J. 2007, "A multi-scale model of dendritic cell education and trafficking in the lung:implications for T cell polarization", Annals of Biomedical Engineering, vol. 35, no. 6, pp. 937-955.

Klinke II, D.J. 2006, "The ratio of P40 monomer to dimer is an important determinant of IL-12 bioactivity", Journal of Theoretical Biology, vol. 240, pp. 323-335.

Klinke, D.J. \& Brundage, K.M. 2009, "Scalable analysis of flow cytometry data using R/Bioconductor.", Cytometry A, vol. 75, pp. 699-706.

Komita, H., Homma, S., Saotome, H., Zeniya, M., Ohno, T. \& Toda, G. 2006, "Interferon-gamma produced by interleukin-12-activated tumor infiltrating CD8+T cells directly induces apoptosis of mouse hepatocellular carcinoma", Journal of Hepatology, vol. 45, pp. 662672.

Kumar, M., Kong, X., Behera, A.K., Hellermann, G.R., Lockey, R.F. \& Mohapatra, S.S. 2003, "Chitosan-IFN-ү-pDNA nanoparticle (CIN) therapy for allergic asthma", Genetic Vaccines and Therapy, vol. 1, no. 3, pp. 1-10.

Lawless, V.A., Zhang, S., Ozes, O.N., Bruns, H.A., Oldham, I., Hoey, T., Grusby, M.J. \& Kaplan, M.H. 2000, "STAT4 regulates multiple components of IFN- $y$-inducing signaling pathways", Journal of Immunology, vol. 165, pp. 6803-6808.

Lee, Y.K., Turner, H., Maynard, C.L., Oliver, J.R., Chen, D.q., Elson, C.O. \& Weaver, C.T. 2009, "Late developmental plasticity in the T helper 17 lineage", Immunity, vol. 30, pp. 92-107.

Letterio, J.J. 2005, "TGF- $\beta$ signaling in T cells:role in lymphoid and epithelial neoplasia", Oncogene, vol. 24, pp. 5701-5712.

Levy, D.E. \& Darnell Jr., J.E. 2002, "STATS:transcriptional control and biological impact", Nature Reviews, vol. 3, pp. 651-662.

Li, L., Qi, X., Williams, M., Shi, Y. \& Keegan, A.D. 2002, "Overexpression of insulin receptor substrate-1,but not insulin receptorsubstrate2 ,protects a $T$ cell hybridoma from activation-induced cell death", Journal of Immunology, vol. 168, pp. 6215-6223. 
Lim, C.P. \& Cao, X. 2006, "Structure, function and regulation of STAT proteins", Molceular Biosystems, vol. 2, pp. 536-550.

Ling, P., Gately, M.K., Gubler, U., Stern, A.S., Lin , P., Hollfelder, K., Su, C., Pan, Y.E. \& Hakimi, J. 1995, "Human IL-12 p40 homodimer binds to the IL-12 receptor but does not mediate biologic activity", Journal of Immunology, vol. 154, no. 1, pp. 116-127.

Maeda, H. \& Shiraishi, A. 1996, "TGF- $\beta$ contributes to the shift toward Th2-type responses through direct and IL-10-mediated pathways in tumor-bearing mice", Journal of Immunology, , pp. 73-78.

Massague, J. 2000, "How cells read TGF- $\beta$ signals", Nature Reviews, vol. 1, pp. 169-178.

Mathur, A.N., Chang, H.C., Zisoulis, D.G., Stritesky, G.L., Yu, Q., O'Malley, J.T., Kapur, R., Levy, D.E., Kansas, G.S. \& Kaplan, M.H. 2007, "Stat3 and Stat4 direct development of IL-17-secreting cells", Journal of Immunology, vol. 178, pp. 4901-4907.

Morinobu, A., Gadina, M., Strober, W., Visconti, R., Fornace, A., Montagna, C., Feldman, G.M., Nishikomori, R. \& O'Shea, J.J. 2002, "STAT4 serine phosphorylation is critical for IL-12-induced IFNgamma productionbut not for cell proliferation", Proceedings of the National Academy of Sciences, vol. 99, no. 19, pp. 12281-12286.

Nakagawa, Y., Tsuruoka, M., Ogura, H., Okuyama, Y., Arima, Y., Hirano, T. \& Murakami, M. 2009, "IL-6 positively regulates Foxp3+CD8+ T cells in vivo", International Immunology, vol. 22, no. 2, pp. 129-139.

Nam, J.S., Terabi, M., Kang, M., Chae, H., Voong, N., Yang, Y., Laurence, A., Michalowska, A., Mamura, M., Lonning, S., Berzofsky, J.A. \& Wakefield, L.M. 2008, "Transforming growth factor $\beta$ subverts the immune system into directly promoting tumor growth through interleukin-17", Cancer Research, vol. 68, no. 10, pp. 3915-3923.

Nishihara, M., Ogura, H., Ueda, N., Tsuruoka, M., Kitabayashi, C., Tsuji, F., Aono, H., Ishihara, K., Huseby, E., Betz, U.A.K., Muarakami, M. \& Hirano, T. 2007, "IL-6-gp130-STAT3 in Tcell directs the development of IL-17 + Th with a minimum effect on that of Treg in the steady state", International Immunology, vol. 19, no. 6, pp. 695-702.

Ogura, H., Murakami, M., Okuyama, Y., Tsuruoka, M., Kitabayashi, C., Kanamoto, M., Nishihara, M., Iwakura, Y. \& Hirano, T. 2008, "Interleukin 17 promotes autoimmunity by triggering a positive- 
feedback loop via interleukin-6 induction", Immunity, vol. 29, pp. 628-636.

Orcy, R.B., Brum, I., da Silva, R.S.M., Kucharski, L.C.R., Corleta, H.v.E. \& Capp, E. 2005, "Insulin receptor tyrosine kinase activity and substrate 1 (IRS-1) expression in human myometrium and leiomyoma", European Journal of Obstetrics \& Gynecology and Reproductive Biology, vol. 123, pp. 107-110.

Pardoux, C., Ma, X., Gobert, S., Pellegrini, S., Mayeux, P., Gay, F., Trinchieri, G. \& Chouaib, S. 1999, "Downregulation of intreleukin-12 (IL-12) responsiveness in human T cells by transforming growth factor-beta:realtionship with IL-12 signaling", Blood, vol. 93, pp. 1448-1455.

Paul, W.E. \& Zhu, J. 2010, "How are $\mathrm{T}_{\mathrm{H}}$ 2-type immune responses initiated and amplified?", Nature Reviews, vol. 10, pp. 225-235.

Rieseberg, M., Kasper, C., Reardon, K.F. \& Scheper, T. 2001, "Flow cytometry in biotechnology", Applied Microbiology and Biotechnology, vol. 56, pp. 350-360.

Rudenski, A.Y., Preston-Hulburt, P., Hong, S., Barlow, A. \& Janeway Jr., C.A. 1991, "Sequence analysis of peptides bound to MHC class II molecules", Nature, vol. 353, pp. 622-627.

Sengupta, T.K., Talbot, E.S., Scherle, P.A. \& Ivashkiv, L.B. 1998, "Rapid inhibition of interleukin- 6 signaling and Stat 3 activation mediated by mitogen-activated protein kinases", Proceedings of the National Academy of Sciences, vol. 95, pp. 11107-11112.

Shi, Y. \& Massague, J. 2003, "Mechanisms of TGF- $\beta$ signaling from cell membrane to the nucleus", Cell, vol. 113, no. 6, pp. 685-700.

Showe, L.C., Fox, F.E., Williams, D., Au, K., Niu, Z. \& Rook, A.H. 1999, "Depressed IL-12-mediated signal transduction in T cells from patients with Sezary syndrome is associated with the absence of the IL-12 receptor $\beta 2$ mRNA and highly reduced levels of STAT4", The Journal of Immunology, vol. 163, pp. 4073-4079.

Soto, P., Price-Schiavi, S.A. \& Carraway, K.L. 2003, "SMAD2 and SMAD7 involvement in the post-translational regulation of Muc4 via the transforming growth factor- $\beta$ and interferon- $\gamma$ pathways in ratmammary epithelial cells", Journal of Biological Chemistry, vol. 278, no. 22. 
Sudarshan, C., Galon, J., Zhou, Y. \& O'Shea, J.J. 1999, "TGF- $\beta$ does not inhibit IL-12- and IL-12-induced activation of Janus kinases and STATs", Journal of Immunology, , pp. 2974-2981.

Sykiotis, G.P. \& Papavassiliou, A.G. 2001, "Serine phosphorylation of insulin receptor substrate-1:a novel target for the reversal of insulin resistance", Molecular Endocrinology, vol. 15, no. 11, pp. 1864-1869.

Takeda, K., Kaisho, T., Yoshida, N., Takeda, J., Kishimoto, T. \& Akira, S. 1998, "STAT3 activation is responsible for IL-6-dependent T cell proliferation through preventing apoptosis:generation and chracaterization of T-cell specific STAT3-deficient mice", Journal of Immunology, vol. 161, pp. 4652-4660.

VanderLaan, P.A. \& Reardon, C.A. 2005, "The unusual suspects:an overview of the minor leukocyte populations in atherosclerosis", Journal of Lipid Research, vol. 46.

Viardot, A., Grey, S.T., Mackay, F. \& Chisholm, D. 2007, "Potential antiinflammatory role of insulin via the preferential polarization of effector T cells toward a T helper 2 phenotype", Endocrinology, vol. 148 , no. 1, pp. 346-353.

Wang, L., Yi, T., Kortylewski, M., Pardoll, D.M., Zeng, D. \& Yu, H. 2009, "IL-17 can promote tumor growth through an IL-6-Stat3 signaling pathway", Journal of Experimental Medicine, vol. 206, no. 7, pp. 1457-1464.

Wang, S., Boonman, Z.F.H.M., Li, H., He, Y., Jager, M.J., Toes, R.E.M. \& Niederkorn, J.Y. 2003, "Role of TRAIL and IFN-gamma in CD4+T celldependent tumor rejection in the anterior chamber of the eye", Journal of Immunology, vol. 171, pp. 2789-2796.

Wilson, C.B., Rowell, E. \& Sekimata, M. 2009, "Epigenetic control of Thelper-cell differentiation", Nature Reviews, vol. 9, pp. 91-105.

Yamamoto, K., Yamaguchi, M., Miyasaka, N. \& Miura, O. 2003, "SOCS-3 inhibits IL-12 induced STAT4 activation by binding through its SH2 domain to the STAT4 docking site in the IL-12 receptor $\beta 2$ subunit", Biochemical and Biophysical Research Communications, vol. 310, no. 1188, pp. 1193.

Yokoyama, W.M., Kim, S. \& French, A.R. 2004, "The dynamic life of natural killer cells", Annual Review of Immunology, vol. 22, pp. 12.112.25 . 
Zheng, S.G., Gray, J.D., Ohtsuka, K., Yamagiwa, S. \& Horwitz, D.A. 2002, "Generation ex vivo of TGF- $\beta$-producing regulatory $T$ cells from CD4+ CD25- precursors", Journal of Immunology, vol. 169, pp. 41834189.

Zhong, Z., Wen, Z. \& Darnell, J.E. 1994, "STAT3 and STAT4:members of the family of signal transducers and activators of transcription", Proceedings of the National Academy of Sciences, vol. 91, pp. 48064810.

Zhou, L., Ivanov, I.I., Spolski, R., Min, R., Shenderov, K., Egawa, T., Levy, D.E., Leonard, W.J. \& Litman, D.R. 2007, "IL-6 programs T(H)-17 cell differentiation by promoting sequential engagement of the IL-21 and IL-23 pathways.", Nature Immunology, vol. 8, pp. 967-974. 


\section{APPENDIX A}

\section{Sample R/Bioconductor code for analysis of data}

\#In this experiment, we starved the 2D6 cells for 12 hours without IL-12, prior to stimulation with insulin.

\#The cell line used is the $2 D 6$ cell line, a T helper cell line. The cells were

\#stained for IL-12R\$beta\$2, and PSTAT4 at time ohr, $12 \mathrm{hr}, 15 \mathrm{~min}, 1 \mathrm{hr}, 2 \mathrm{hr}$ following the addition of insulin and/or IL-12.

\#The concentrations of IL-12, aliquoted in BSA, is $40 \mathrm{ng} / \mathrm{ml}$. Cell density and ratio of $2 \mathrm{D} 6$ and $\mathrm{B} 16$ changes.

\#normally $2 \mathrm{D} 6$ at $6 \times 10 \wedge 4$ cell\$/well\$, 2-stand for 2D6 at $1.2 \times 10 \wedge 5$ cell\$/well\$.

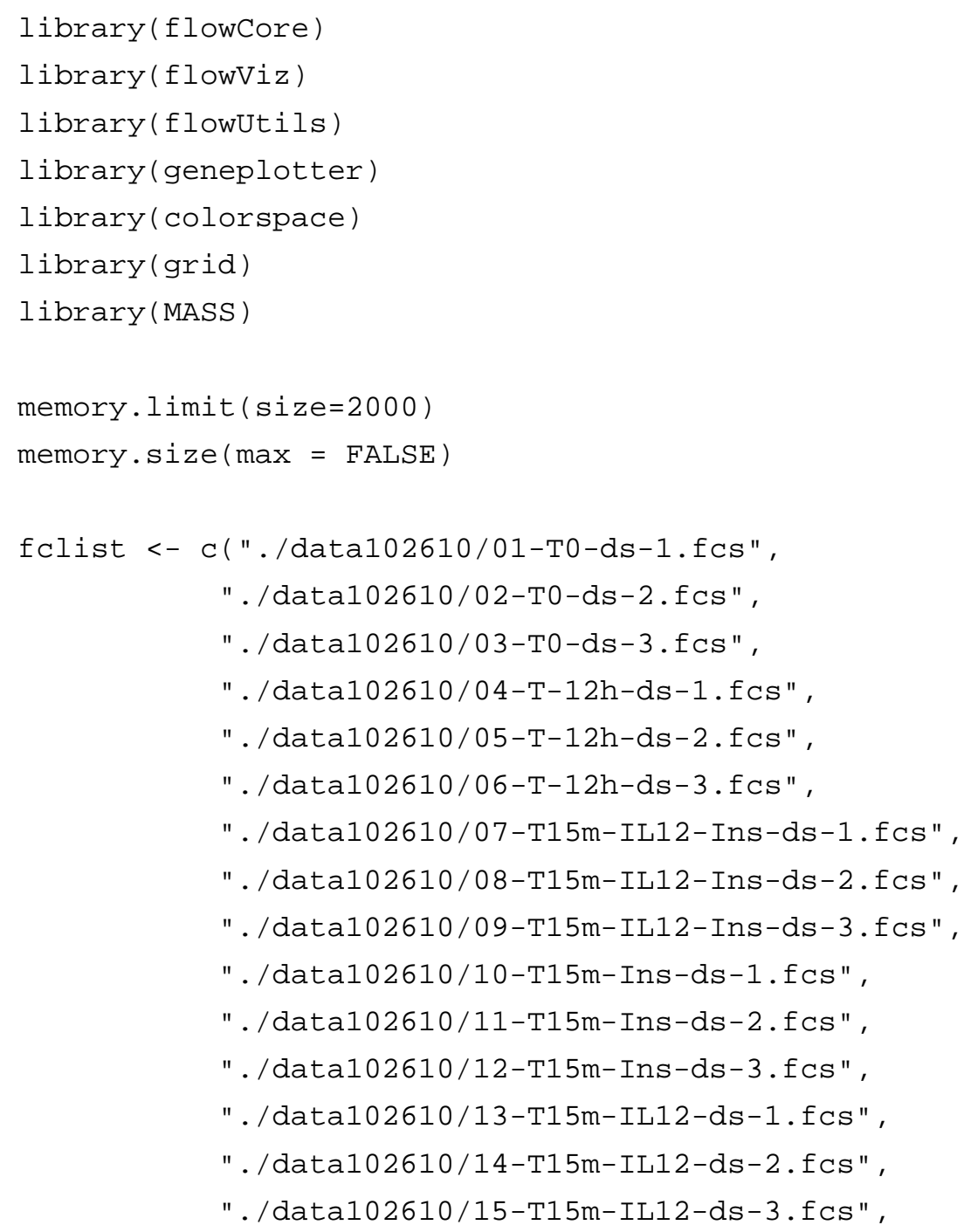


". /data102610/16-T15m-nostim-ds-1.fcs",

". /data102610/17-T15m-nostim-ds-2.fcs",

". /data102610/18-T15m-nostim-ds-3.fcs",

". /data102610/19-T1h-IL12-Ins-ds-1.fcs",

". /data102610/20-T1h-IL12-Ins-ds-2.fcs",

". /data102610/21-T1h-IL12-Ins-ds-3.fcs",

". /data102610/22-T1h-Ins-ds-1.fcs",

". /data102610/23-T1h-Ins-ds-2.fcs",

". /data102610/24-T1h-Ins-ds-3.fcs",

". /data102610/25-T1h-IL12-ds-1.fcs",

". /data102610/26-T1h-IL12-ds-2.fcs",

". /data102610/27-T1h-IL12-ds-3.fcs",

". /data102610/28-T1h-nostim-ds-1.fcs",

". /data102610/29-T1h-nostim-ds-2.fcs",

". /data102610/30-T1h-nostim-ds-3.fcs",

". /data102610/31-T2h-IL12-Ins-ds-1. fcs",

". /data102610/32-T2h-IL12-Ins-ds-2 . fcs",

". /data102610/33-T2h-IL12-Ins-ds-3.fcs",

". /data102610/34-T2h-Ins-ds-1.fcs",

". /data102610/35-T2h-Ins-ds-2.fcs",

". /data102610/36-T2h-Ins-ds-3.fcs",

". /data102610/37-T2h-IL12-ds-1.fcs",

". /data102610/38-T2h-IL12-ds-2.fcs",

". /data102610/39-T2h-IL12-ds-3.fcs",

". /data102610/40-T2h-nostim-ds-1.fcs",

". /data102610/41-T2h-nostim-ds-2.fcs",

"./data102610/42-T2h-nostim-ds-3.fcs" )

\#for compensation matrix only -com

fclistcom <- c("./data102610/T15m-ns-control.fcs",

". /data102610/T15m-ss-IL12RB2.fCs",

". /data102610/T15m-ss-pSTAT4.fcs")

fs <- read.flowset (fclist, transformation = FALSE)

fscom <- read.flowset (fclistcom, transformation $=$ FALSE)

Tclist <- c("01-TO-ds-1",

"๑2-T९-ds-2",

"๑3-T९-ds-3",

"๑4-T-12h-ds-1",

"05-T-12h-ds-2",

"๑6-T-12h-ds-3",

"07-T15m-IL12-Ins - ds - 1",

"๑8-T15m-IL12-Ins-ds-2",

"09-T15m-IL12-Ins-ds-3", 


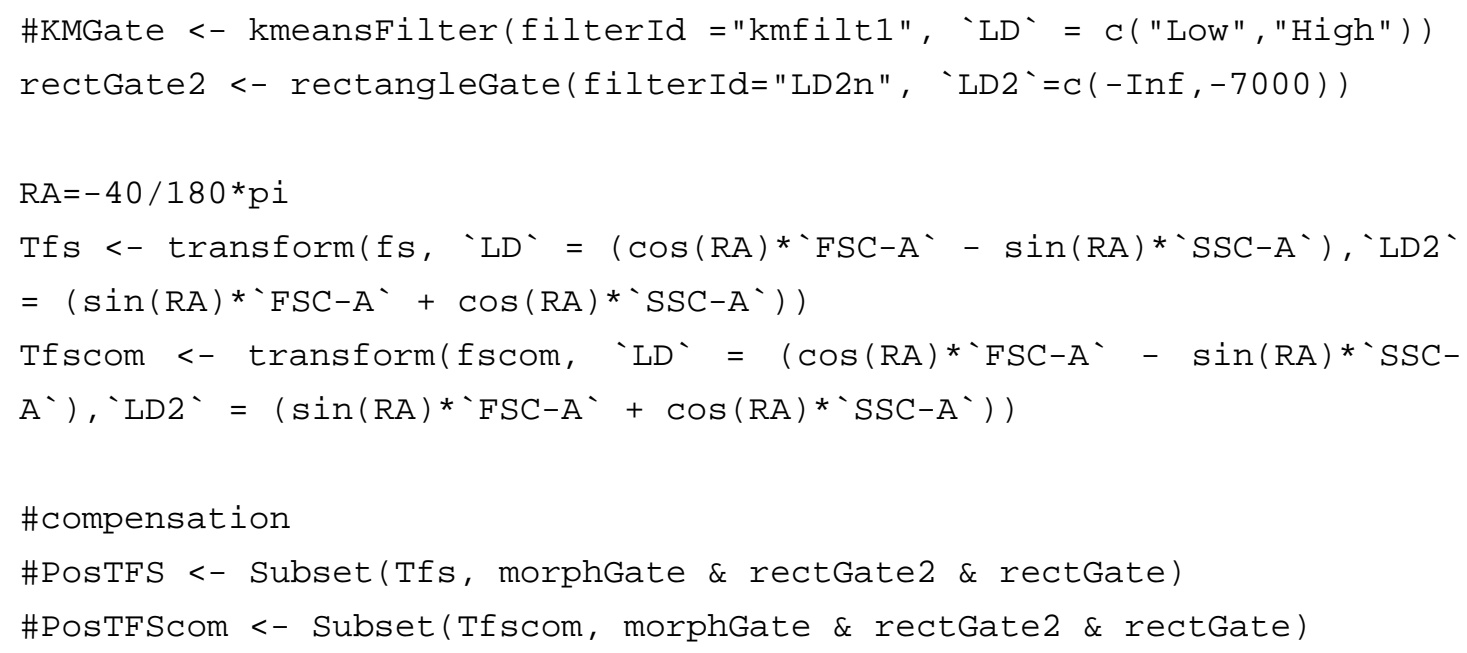




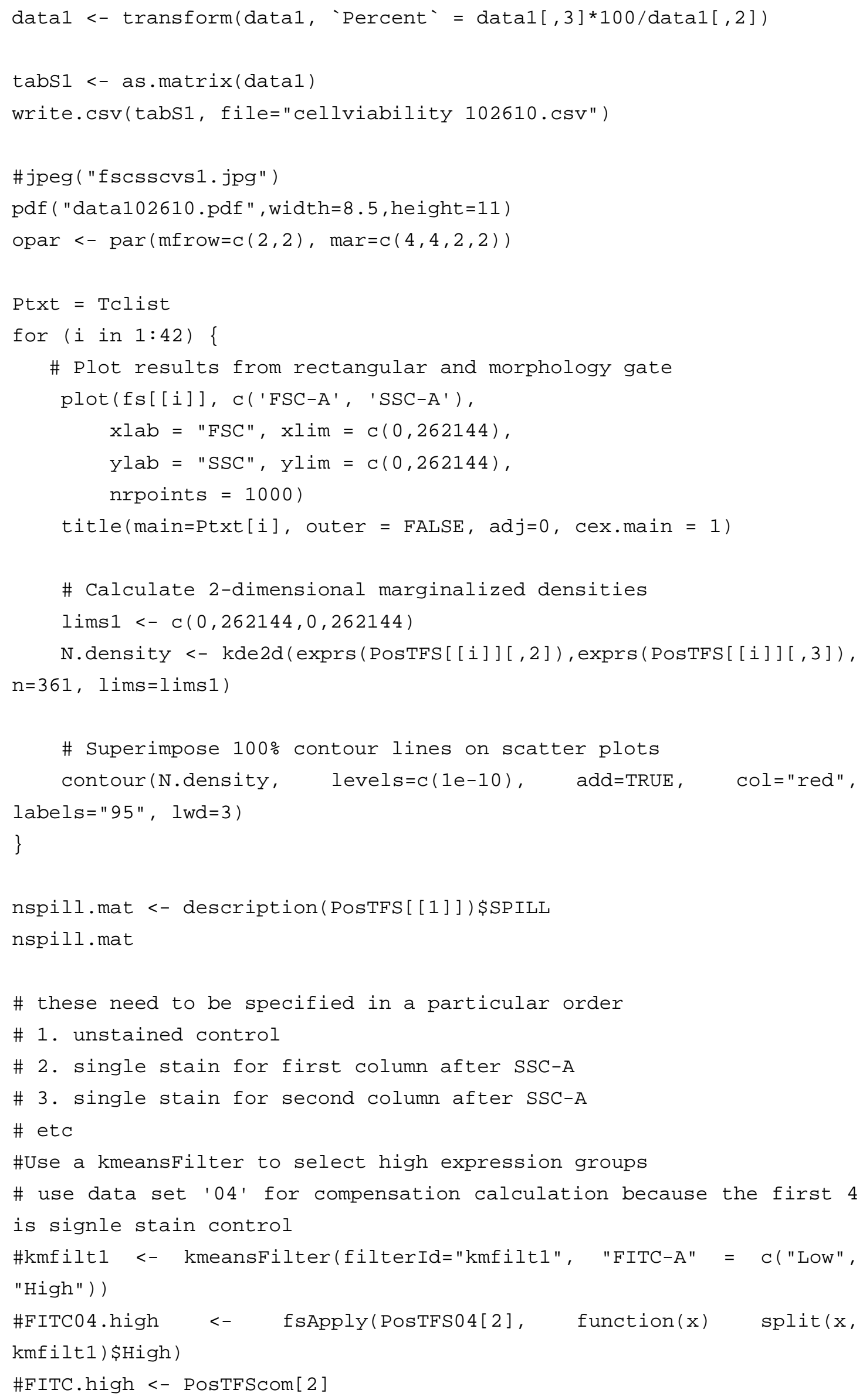




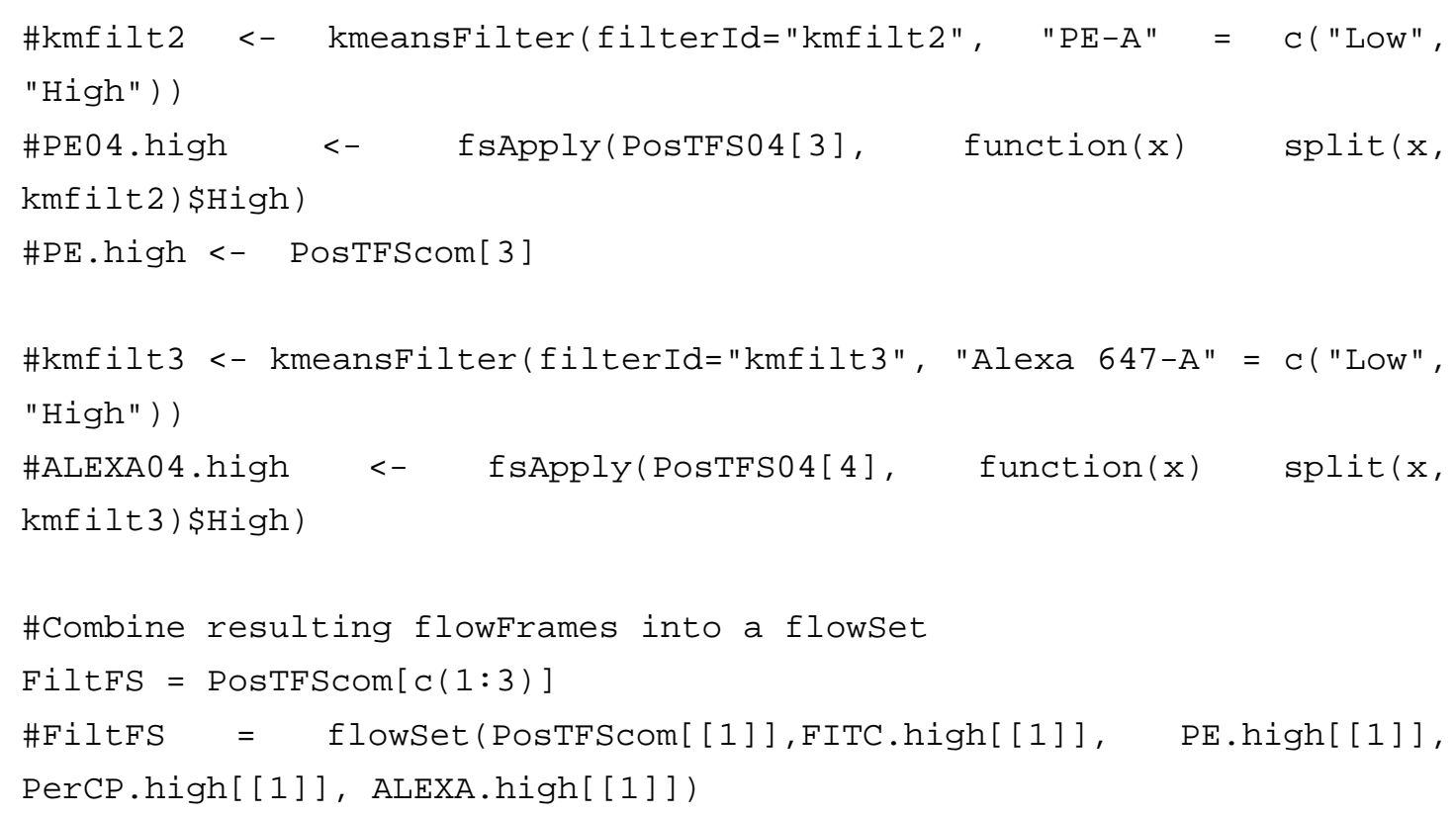




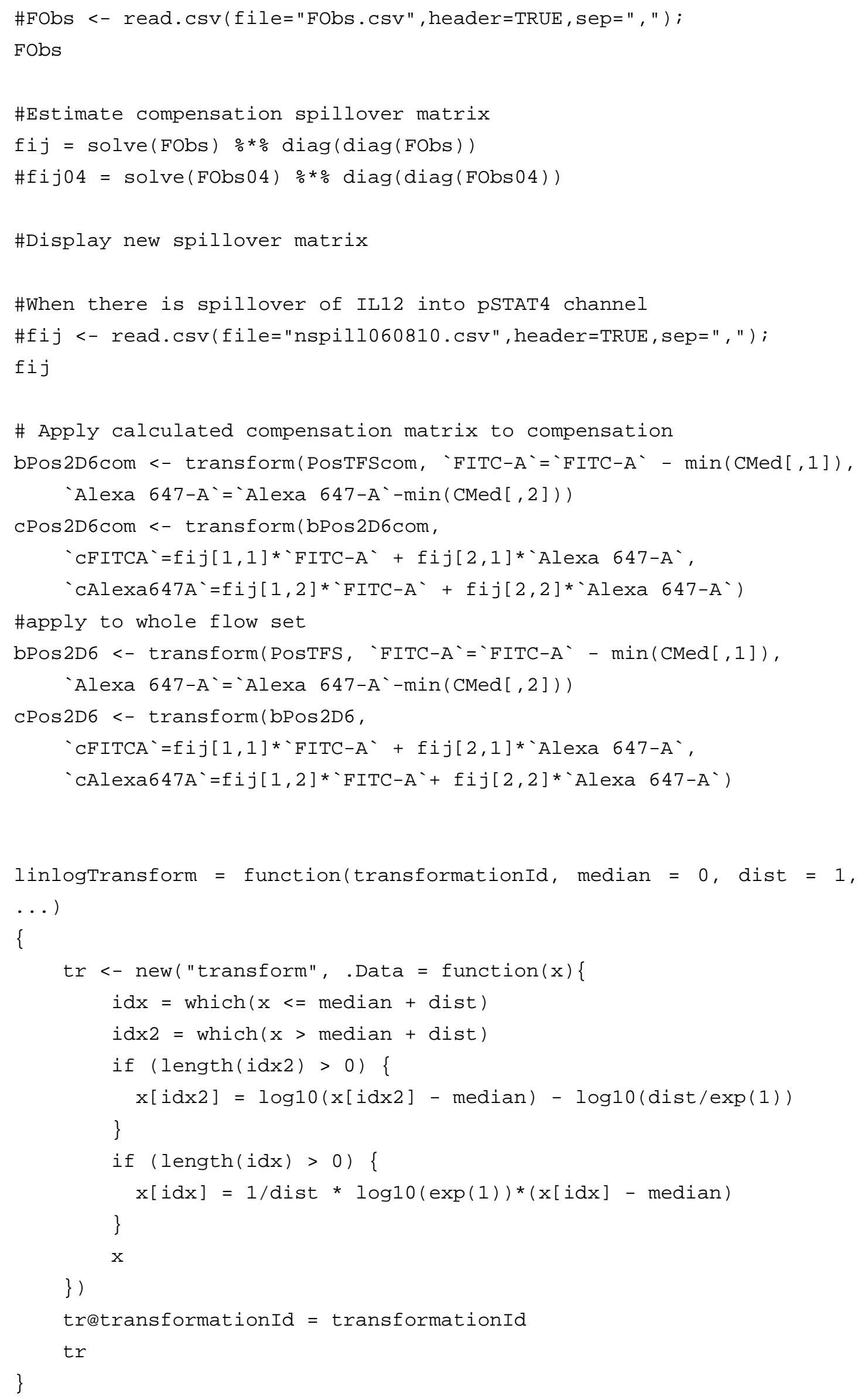


lnlgT <- linlogTransform(transformationId="splitscale", median=0, dist $=100$ )

\#Calculate $X$-labels for graphs

lnlgTGraphs <- linlogTransform(transformationId="splitscale", median $=0$, dist $=100$ )

Xloc <- lnlgTGraphs(c(-200, -150, -100, -50, $\odot, 50,100,150,200$, $250,400,550,700,850,1000$,

$2500,4000,5500,7000,8500,10000$,

$25000,40000,55000,70000,85000,100000))$

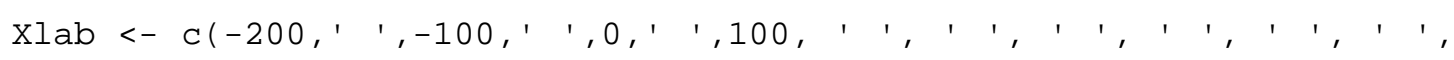
' ',

expression(10^3), ' ', ' ', ' ', ' ', ' ', expression(10^4),

' ', ' ', ' ', ' ', ' ', expression(10^5))

cPos2D6com <- transform(CPos2D6com, 'IL12RB2`=lnlgT( 'CFITCA $)$,

'pSTAT4`=lnlgT( ‘cAlexa647A`))

CPos2D6 <- transform(CPos2D6, 'IL12RB2`=lnlgT( 'CFITCA ) ,

'pSTAT4`=lnlgT( ‘cAlexa647A`))

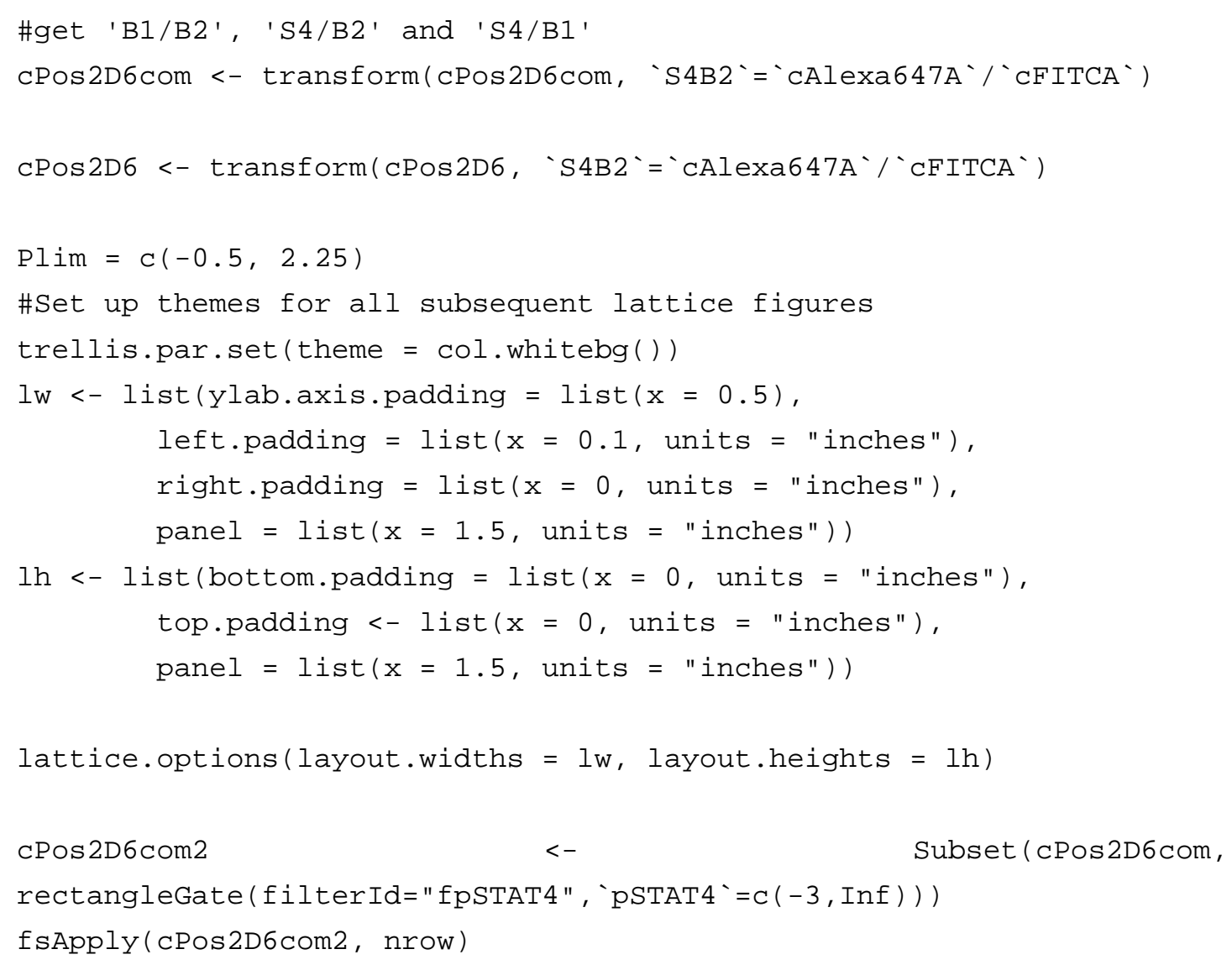




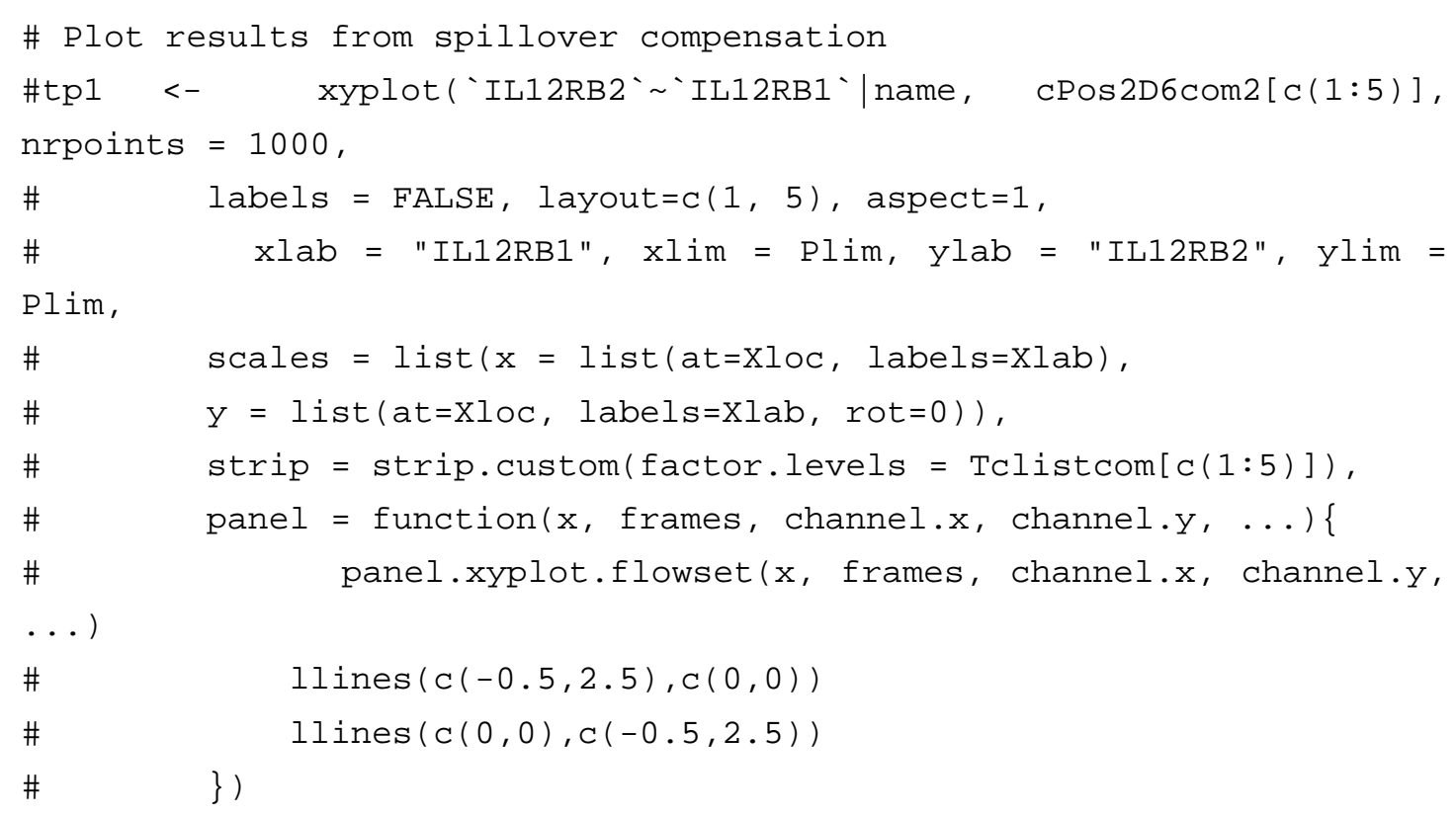




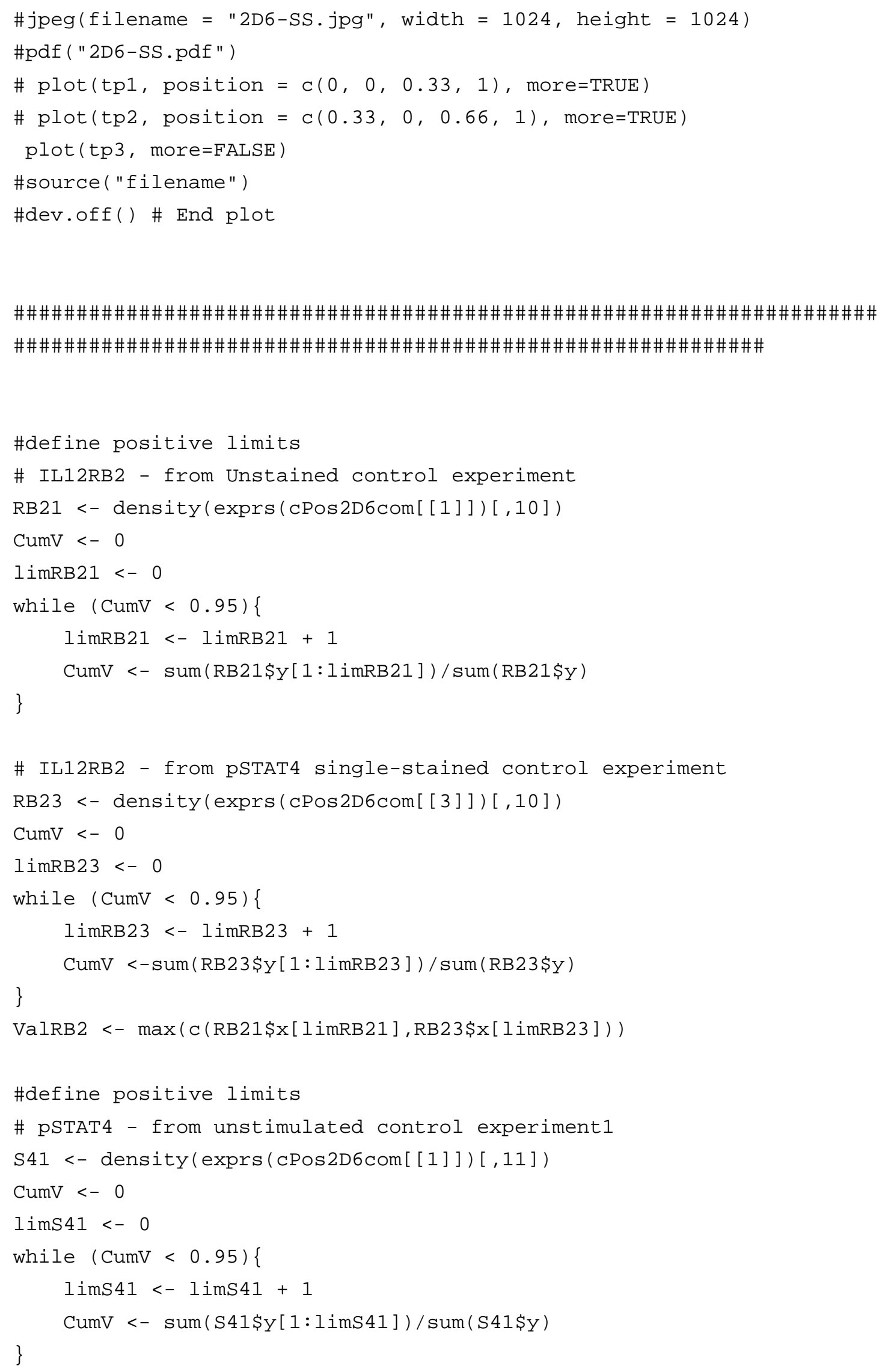




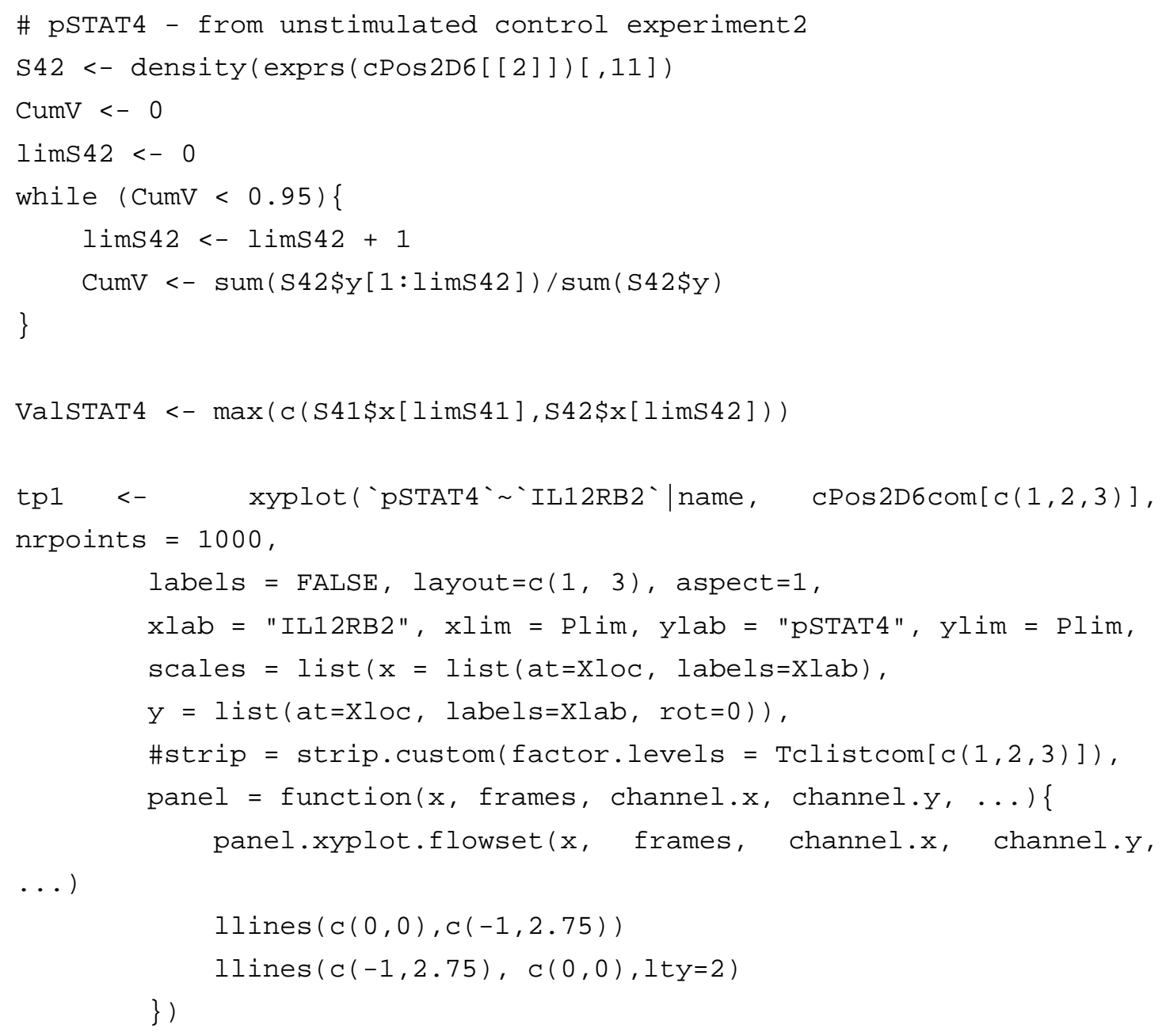




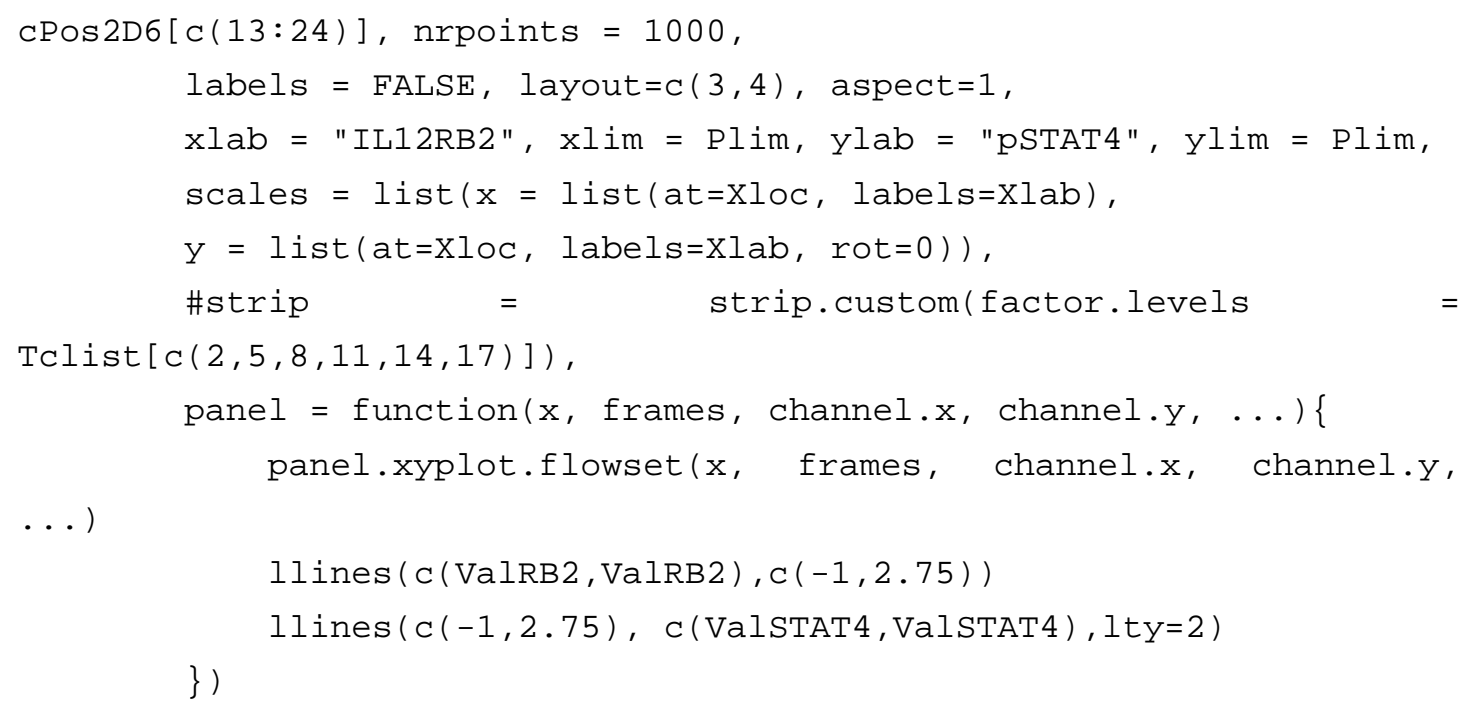




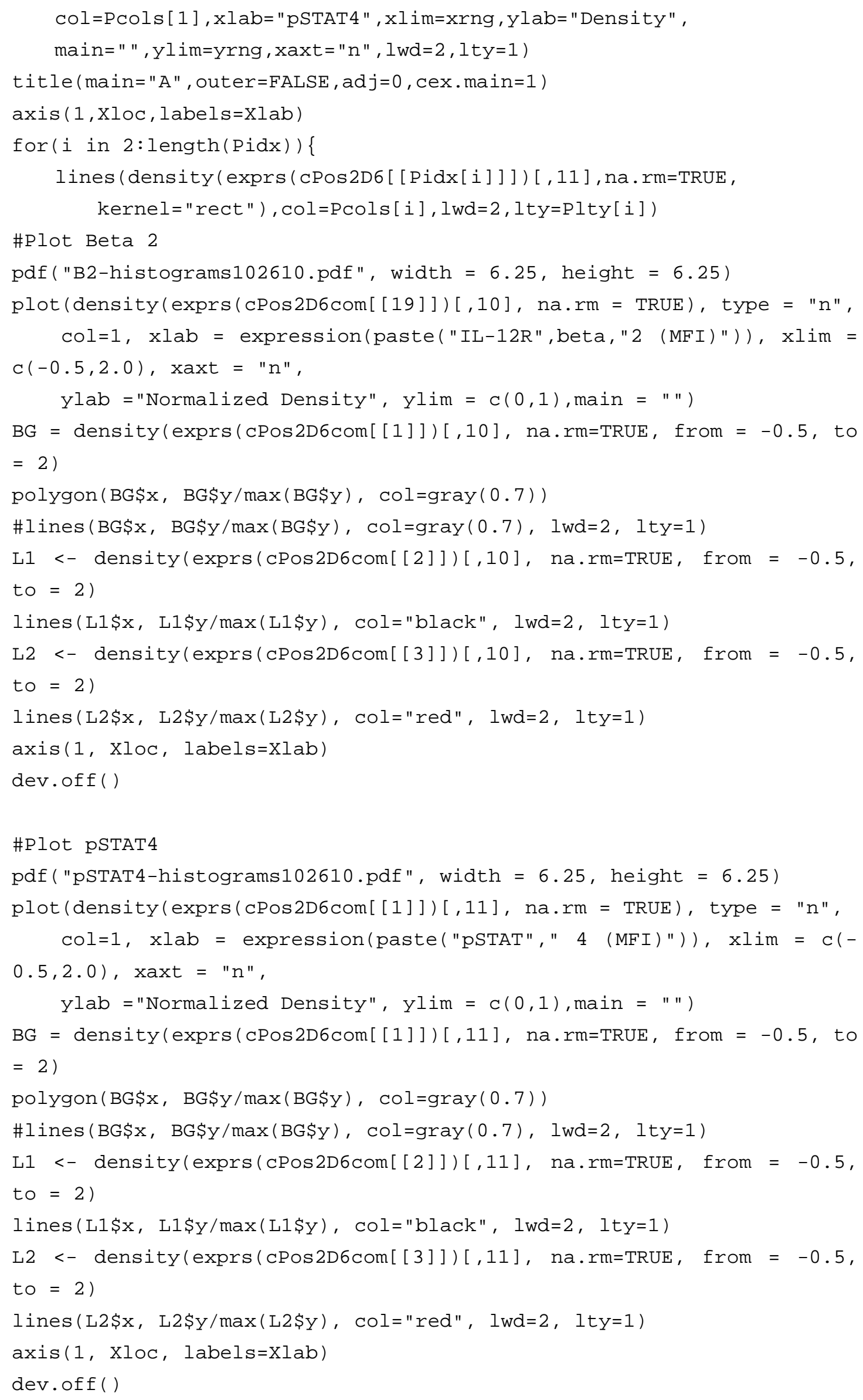




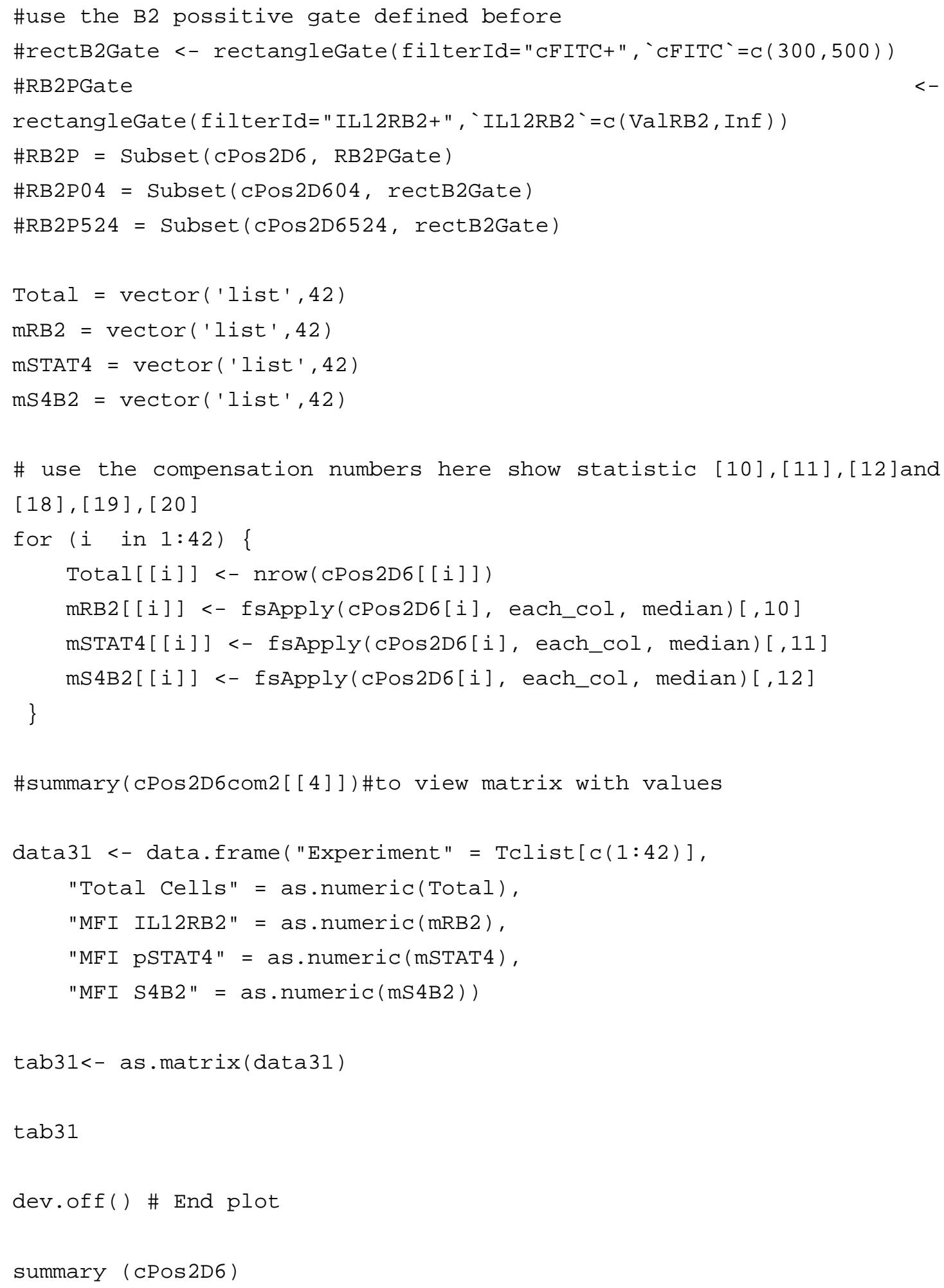




\section{APPENDIX B}

\section{Representative no stain and single stain control plots}
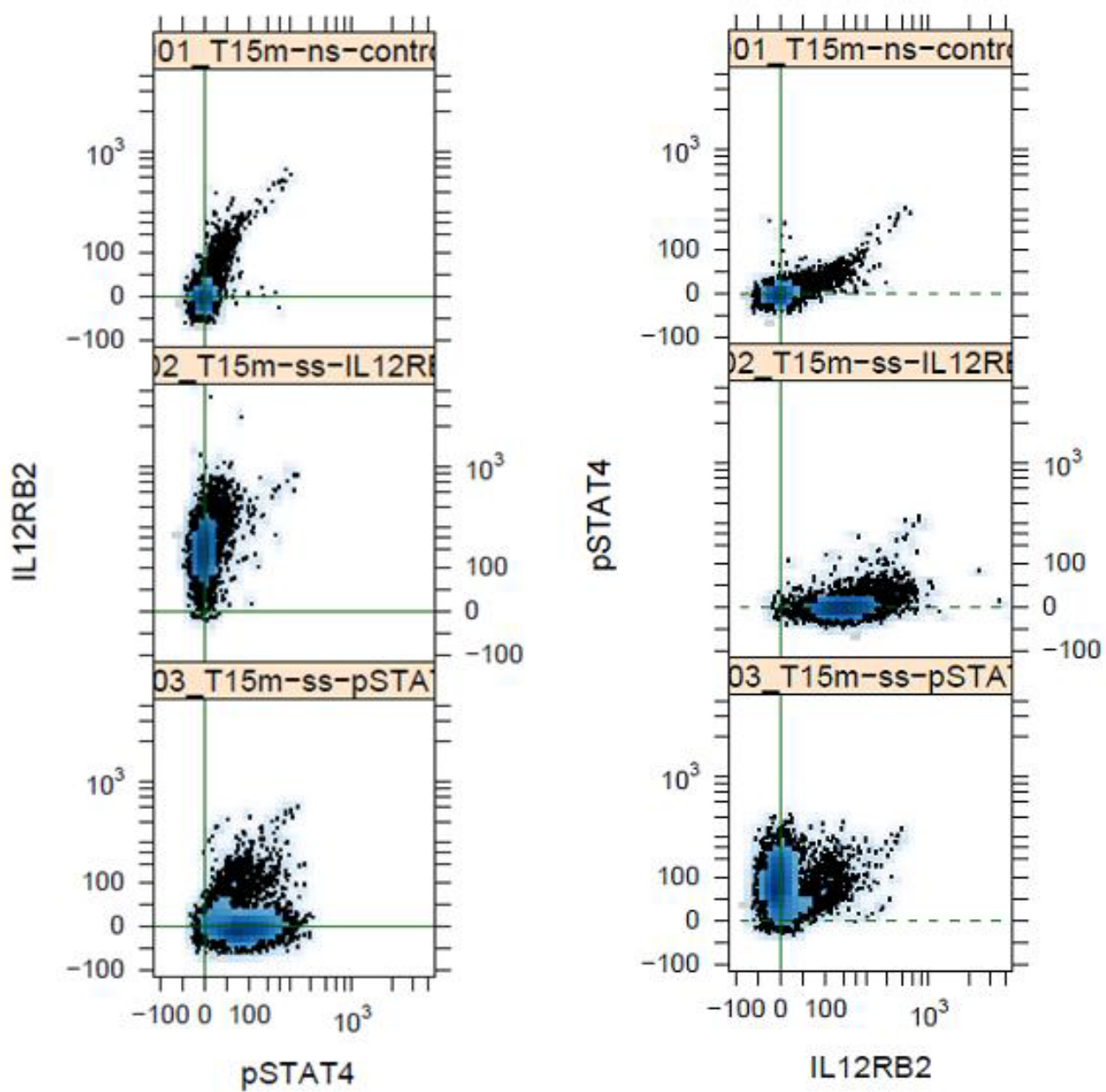

Figure 1. Single stain controls for pSTAT4 and IL-12R $\beta 2$ used for compensation by representing each one a positive signal in its own channel only. Top panels are no stain controls, middle left and bottom right are single stain controls for IL-12R $\beta 2$, and middle right and bottom left are single stain controls for pSTAT4. 


\section{APPENDIX C}

\section{Statistical analysis of treatment groups}

\section{Effect of TGF- $\beta$ on pSTAT4}

\subsection{Effect of TGF- $\beta$ after 15 minutes}

Two-way ANOVA: pSTAT4 versus TGF-beta; IL-12

$\begin{array}{lrrrrr}\text { Source } & \text { DF } & \text { SS } & \text { MS } & F & P \\ \text { TGF-beta } & 1 & 42,075 & 42,075 & 6,77 & 0,031 \\ \text { IL-12 } & 1 & 325,833 & 325,833 & 52,46 & 0,000 \\ \text { Interaction } & 1 & 25,667 & 25,667 & 4,13 & 0,077 \\ \text { Error } & 8 & 49,688 & 6,211 & & \\ \text { Total } & 11 & 443,263 & & & \\ & & & & & \\ \text { S = 2,492 } & \text { R-Sq }=88,79 \% & \text { R-Sq(adj })=84,59 \%\end{array}$

\subsection{Effect of TGF- $\beta$ after 1 hour}

Two-way ANOVA: pSTAT4 versus TGF-beta; IL-12

$\begin{array}{lrrrrr}\text { Source } & \text { DF } & \text { SS } & \text { MS } & F & P \\ \text { TGF-beta } & 1 & 257,75 & 257,752 & 1,46 & 0,262 \\ \text { IL-12 } & 1 & 486,60 & 486,604 & 2,75 & 0,136 \\ \text { Interaction } & 1 & 51,32 & 51,315 & 0,29 & 0,605 \\ \text { Error } & 8 & 1415,78 & 176,973 & \\ \text { Total } & 11 & 2211,46 & & & \\ & & & & \\ \text { S = 13,30 } & \text { R-Sq }=35,98 \% & \text { R-Sq(adj) }=11,97 \%\end{array}$

\subsection{Effect of TGF- $\beta$ after 2 hours}

Two-way ANOVA: pSTAT4 versus TGF-beta; IL-12

$\begin{array}{lrrrrr}\text { Source } & \text { DF } & \text { SS } & \text { MS } & \text { F } & \text { P } \\ \text { TGF-beta } & 1 & 1842,89 & 1842,89 & 103,08 & 0,000 \\ \text { IL-12 } & 1 & 4681,15 & 4681,15 & 261,84 & 0,000\end{array}$




\begin{tabular}{|c|c|c|c|c|c|}
\hline Interaction & 1 & 925,59 & 925,59 & 51,77 & $\odot, \odot \odot \odot$ \\
\hline Error & 8 & 143,02 & 17,88 & & \\
\hline Total & 11 & 7592,64 & & & \\
\hline$S=4,228$ & $\mathrm{R}-\mathrm{Sq}$ & $=98,12 \%$ & $\mathrm{R}-\mathrm{Sq}($ & j) $=97$ & , 41\% \\
\hline
\end{tabular}

\section{Effect of TGF- $\beta$ on cell viability}

\subsection{Effect of TGF- $\beta$ after 15 minutes}

Two-way ANOVA: Live cell percent versus TGF-beta; IL-12

$\begin{array}{lrrrrr}\text { Source } & \text { DF } & \text { SS } & \text { MS } & F & P \\ \text { TGF-beta } & 1 & 0,074 & 0,0736 & 0,01 & 0,939 \\ \text { IL-12 } & 1 & 19,051 & 19,0512 & 1,63 & 0,237 \\ \text { Interaction } & 1 & 16,709 & 16,7088 & 1,43 & 0,265 \\ \text { Error } & 8 & 93,233 & 11,6541 & & \\ \text { Total } & 11 & 129,066 & & & \\ & & & & & \\ \text { S }=3,414 & \text { R-Sq }=27,76 \% & \text { R-Sq(adj })=0,68 \%\end{array}$

\subsection{Effect of TGF- $\beta$ after 1 hour}

Two-way ANOVA: Live cell percent versus TGF-beta; IL-12

$\begin{array}{lrrrrr}\text { Source } & \text { DF } & \text { SS } & \text { MS } & F & P \\ \text { TGF-beta } & 1 & 251,534 & 251,534 & 9,85 & 0,014 \\ \text { IL-12 } & 1 & 2,595 & 2,595 & 0,10 & 0,758 \\ \text { Interaction } & 1 & 77,216 & 77,216 & 3,02 & 0,120 \\ \text { Error } & 8 & 204,232 & 25,529 & & \\ \text { Total } & 11 & 535,576 & & & \\ & & & & \\ \text { S }=5,053 & \text { R-Sq }=61,87 \% & \text { R-Sq(adj })=47,57 \%\end{array}$

\subsection{Effect of TGF- $\beta$ after 2 hours}

Two-way ANOVA: Live cell percent versus TGF-beta; IL-12

$\begin{array}{lrrrrr}\text { Source } & \text { DF } & \text { SS } & \text { MS } & \text { F } & \text { P } \\ \text { TGF-beta } & 1 & 256,364 & 256,364 & 22,41 & 0,001 \\ \text { IL-12 } & 1 & 124,775 & 124,775 & 10,91 & 0,011\end{array}$




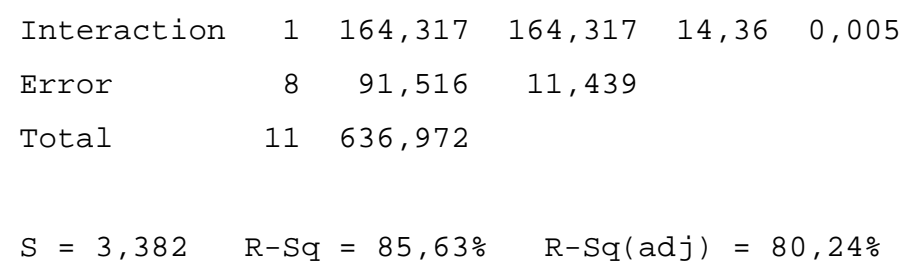

3. Effect of time and treatment with insulin

\subsection{Effect of Insulin after 15 minutes}

Two-way ANOVA: pSTAT4 versus Insulin; IL-12

$\begin{array}{lrrrrr}\text { Source } & \text { DF } & \text { SS } & \text { MS } & F & P \\ \text { Insulin } & 1 & 2,253 & 2,253 & 0,17 & 0,694 \\ \text { IL-12 } & 1 & 126,750 & 126,750 & 9,38 & 0,016 \\ \text { Interaction } & 1 & 36,053 & 36,053 & 2,67 & 0,141 \\ \text { Error } & 8 & 108,160 & 13,520 & & \\ \text { Total } & 11 & 273,217 & & & \\ & & & & \\ \mathrm{~S}=3,677 & \mathrm{R}-\mathrm{Sq}=60,41 \% & \mathrm{R}-\mathrm{Sq}(\operatorname{adj})=45,57 \%\end{array}$

\subsection{Effect of Insulin after 1 hour}

Two-way ANOVA: pSTAT4 versus Insulin; IL-12

$\begin{array}{lrrrrr}\text { Source } & \text { DF } & \text { SS } & \text { MS } & F & P \\ \text { Insulin } & 1 & 29,610 & 29,610 & 6,62 & 0,033 \\ \text { IL-12 } & 1 & 498,585 & 498,585 & 111,50 & 0,000 \\ \text { Interaction } & 1 & 65,100 & 65,100 & 14,56 & 0,005 \\ \text { Error } & 8 & 35,772 & 4,471 & & \\ \text { Total } & 11 & 629,067 & & & \\ & & & & & \\ \text { S = 2,115 } & \text { R-Sq }=94,31 \% & \text { R-Sq(adj })=92,18 \%\end{array}$

\subsection{Effect of Insulin after 2 hours}

Two-way ANOVA: pSTAT4 versus Insulin; IL-12

$\begin{array}{lrrrrr}\text { Source } & \text { DF } & \text { SS } & \text { MS } & F & P \\ \text { Insulin } & 1 & 1,73 & 1,73 & 0,54 & 0,484\end{array}$




$\begin{array}{lrrrrr}\text { IL-12 } & 1 & 1128,11 & 1128,11 & 352,10 & \odot, 0 \odot \odot \\ \text { Interaction } & 1 & 65,10 & 65,10 & 20,32 & \odot, 0 \odot 2 \\ \text { Error } & 8 & 25,63 & 3,20 & & \\ \text { Total } & 11 & 1220,57 & & \\ & & & & \\ S=1,790 & \text { R-Sq }=97,90 \% & \text { R-Sq(adj })=97,11 \%\end{array}$

\section{Effect of insulin on cell viability}

\subsection{Effect of Insulin after 15 minutes}

Two-way ANOVA: Live cell percent versus Insulin; IL-12

$\begin{array}{lrrrrr}\text { Source } & \text { DF } & \text { SS } & \text { MS } & F & P \\ \text { Insulin } & 1 & 0,0001 & 0,00013 & 0,00 & 0,995 \\ \text { IL-12 } & 1 & 3,8307 & 3,83070 & 1,17 & 0,311 \\ \text { Interaction } & 1 & 2,8421 & 2,84213 & 0,87 & 0,379 \\ \text { Error } & 8 & 26,1760 & 3,27200 & & \\ \text { Total } & 11 & 32,8490 & & & \\ & & & & \\ \text { S = 1,809 } & \text { R-Sq }=20,31 \% & \text { R-Sq(adj })=0,0 \odot \%\end{array}$

\subsection{Effect of Insulin after 1 hour}

Two-way ANOVA: Live cell percent versus Insulin; IL-12

$\begin{array}{lrrrrr}\text { Source } & \text { DF } & \text { SS } & \text { MS } & F & P \\ \text { Insulin } & 1 & 20,4363 & 20,4363 & 5,78 & 0,043 \\ \text { IL-12 } & 1 & 6,9921 & 6,9921 & 1,98 & 0,197 \\ \text { Interaction } & 1 & 1,0208 & 1,0208 & 0,29 & 0,606 \\ \text { Error } & 8 & 28,2636 & 3,5329 & & \\ \text { Total } & 11 & 56,7129 & & & \\ & & & & \\ \text { S = 1,880 } & \text { R-Sq }=50,16 \% & \text { R-Sq (adj })=31,48 \%\end{array}$

\subsection{Effect of Insulin after 2 hours}

Two-way ANOVA: Live cell percent versus Insulin; IL-12

Source

DF

SS

MS

F 


$\begin{array}{lrrrrr}\text { Insulin } & 1 & 6,571 & 6,5712 & 0,89 & 0,374 \\ \text { IL-12 } & 1 & 24,596 & 24,5960 & 3,31 & 0,106 \\ \text { Interaction } & 1 & 40,333 & 40,3333 & 5,43 & 0,048 \\ \text { Error } & 8 & 59,386 & 7,4233 & & \\ \text { Total } & 11 & 130,887 & & & \\ & & & & \\ \text { S }=2,725 & \text { R-Sq }=54,63 \% & \text { R-Sq }(\operatorname{adj})=37,61\end{array}$

\section{Effect of IL-6 on pSTAT4}

\subsection{Effect of IL- 6 after 15 minutes}

Two-way ANOVA: pSTAT4 versus IL-6; IL-12

$\begin{array}{lrrrrr}\text { Source } & \text { DF } & \text { SS } & \text { MS } & F & P \\ \text { IL-6 } & 1 & 266,492 & 266,492 & 4,18 & 0,075 \\ \text { IL-12 } & 1 & 0,317 & 0,317 & 0,00 & 0,946 \\ \text { Interaction } & 1 & 59,185 & 59,185 & 0,93 & 0,364 \\ \text { Error } & 8 & 510,098 & 63,762 & & \\ \text { Total } & 11 & 836,092 & & & \\ & & & & \\ \text { S = 7,985 } & \text { R-Sq }=38,99 \% & \text { R-Sq(adj })=16,11 \%\end{array}$

\subsection{Effect of IL- 6 after 1 hour}

Two-way ANOVA: pSTAT4 versus IL-6; IL-12

$\begin{array}{lrrrrr}\text { Source } & \text { DF } & \text { SS } & \text { MS } & F & P \\ \text { IL-6 } & 1 & 2,25 & 2,253 & 0,07 & 0,794 \\ \text { IL-12 } & 1 & 225,33 & 225,333 & 7,27 & 0,027 \\ \text { Interaction } & 1 & 813,45 & 813,453 & 26,25 & 0,001 \\ \text { Error } & 8 & 247,87 & 30,983 & & \\ \text { Total } & 11 & 1288,91 & & & \\ & & & & & \\ \text { S = 5,566 } & \text { R-Sq }=80,77 \% & \text { R-Sq(adj })=73,56 \%\end{array}$

\subsection{Effect of IL-6 after 2 hours}

Two-way ANOVA: pSTAT4 versus IL-6; IL-12

Source

DF

SS

MS

$\mathrm{P}$ 


$\begin{array}{lrrrrr}\text { IL-6 } & 1 & 25,667 & 25,667 & 2,31 & 0,167 \\ \text { IL-12 } & 1 & 71,297 & 71,297 & 6,43 & 0,035 \\ \text { Interaction } & 1 & 198,047 & 198,047 & 17,86 & 0,003 \\ \text { Error } & 8 & 88,725 & 11,091 & & \\ \text { Total } & 11 & 383,736 & & & \\ & & & & \\ \text { S }=3,330 & \text { R-Sq }=76,88 \% & \text { R-Sq(adj })=68,21 \%\end{array}$

6. Effect of IL-6 on cell viability

\subsection{Effect of IL-6 after 15 minutes}

Two-way ANOVA: Live cell percent versus IL-6; IL-12

$\begin{array}{lrrrrr}\text { Source } & \text { DF } & \text { SS } & \text { MS } & F & P \\ \text { IL-6 } & 1 & 1,279 & 1,2793 & \odot, 07 & 0,798 \\ \text { IL-12 } & 1 & \odot, 0 \odot 1 & \odot, 0012 & \odot, 0 \odot & \odot, 994 \\ \text { Interaction } & 1 & 10,143 & 10,1427 & 0,56 & 0,477 \\ \text { Error } & 8 & 145,589 & 18,1987 & & \\ \text { Total } & 11 & 157,012 & & & \\ & & & & \\ \text { S }=4,266 & \mathrm{R}-\mathrm{Sq}=7,28 \% & \mathrm{R}-\mathrm{Sq}(\operatorname{adj})=0,0 \odot \%\end{array}$

\subsection{Effect of IL- 6 after 1 hour}

Two-way ANOVA: Live cell percent versus IL-6; IL-12

$\begin{array}{lrrrrr}\text { Source } & \text { DF } & \text { SS } & \text { MS } & F & P \\ \text { IL-6 } & 1 & 34,525 & 34,5252 & 3,66 & 0,092 \\ \text { IL-12 } & 1 & 32,019 & 32,0193 & 3,39 & \odot, 103 \\ \text { Interaction } & 1 & 18,893 & 18,8925 & 2,00 & 0,195 \\ \text { Error } & 8 & 75,493 & 9,4366 & \\ \text { Total } & 11 & 16 \odot, 930 & & & \\ & & & & \\ \text { S }=3,072 & \text { R-Sq }=53,09 \% & \text { R-Sq(adj) }=35,50 \%\end{array}$

\subsection{Effect of IL-6 after 2 hours}

Two-way ANOVA: Live cell percent versus IL-6; IL-12

$\begin{array}{lrrrrr}\text { Source } & \text { DF } & \text { SS } & \text { MS } & F & P \\ \text { IL-6 } & 1 & 38,815 & 38,8149 & 1,86 & 0,210 \\ \text { IL-12 } & 1 & 14,881 & 14,8809 & 0,71 & 0,423\end{array}$




$\begin{array}{lrrrrr}\text { Interaction } & 1 & 59,972 & 59,9718 & 2,87 & 0,129 \\ \text { Error } & 8 & 167,328 & 20,9160 \\ \text { Total } & 11 & 280,996 & \\ & \\ S=4,573 & \text { R-Sq }=40,45 \% & \text { R-Sq(adj) }=18,12 \%\end{array}$




\section{APPENDIX D}

\section{Protocol for Western Blot}

\section{$\underline{\text { Gel Electrophoresis }}$}

1. Place larger glass sheet on bottom (back) and shorter on top (front) and align using black rubber strips (spacers) on sides.

2. Place glasses vertically on holder, press edges to align.

3. Tighten screws up to first resistance (when too tight, it can leak)

4. Snap onto base and add water to check for leaks.

5. Prepare resolving gel using recipe for $5 \mathrm{ml}$ (for $1 \mathrm{gel}$ ) or $10 \mathrm{ml}$ (for 2 gels) and $12 \%$ acrilamide.

6. Pour resolving gel up to hinges on sides, and add a bit of water on top to take care of bubbles (up to top).

7. Let polymerize for 40 minutes.

8. Pour off water from the top of glasses.

9. Prepare 1 or $2 \mathrm{ml}$ of stacking gel as indicated on recipe and pour it on top of resolving gel.

10. Put comb in between glasses right after pouring gel.

11. After 30 minutes, remove comb upright and wash wells with $1 x$ running buffer.

12. Snap glass holder on unit and pour $1 x$ buffer in inner chamber first, and then fill up the rest of the chamber.

13. Add SDS $4 x$ buffer to protein samples for a complete volume of $40 \mu \mathrm{l}$, and boil samples for 3 minutes.

14. Pour samples, controls and ladder into the wells making sure it settles on the bottom.

15. Close chamber and connect to voltage source. 
16. Run at $75 \mathrm{~V}, 350 \mathrm{~mA}(6 \mathrm{~h})$ for 2 hours.

\section{$\underline{\text { Transfer }}$}

1. Cut four $6 \times 9 \mathrm{com}$ pieces of blot paper and one $6 \times 9 \mathrm{~cm}$ piece of membrane for the transfer.

2. Put cassette sandwich with black part down, then put foam piece on black lid and pour 1x Transfer Buffer, then put 2 transfer blot papers, then gel as mirror image on paper, then membrane on top with protein side marked, and repeat sequence in reverse order (Note: keep moist with 1x Transfer buffer at all times).

3. Place cassette sandwich on unit, black side facing black walls of chamber, and white edge of cassette up.

4. Place in bigger chamber, black wall in, with ice packet, and fill with buffer almost to top.

5. Transfer at $42 \mathrm{~V}$ for 1.5 hours.

\section{Blotting}

1. After transfer is finished take membrane out of chamber and place in a WB box to block for $1 \mathrm{hr}$ with $10 \mathrm{ml}$ of Odyssey Blocking Buffer and gentle shaking

2. Put membrane in primary antibody solution (10 ml Blocking Buffer $+0.2 \%$ Tween $20+$ Phospho-Stat3 (Tyr705)-Cell Signaling Technology Inc.) and incubate overnight at $4^{\circ} \mathrm{C}$ and gentle shaking.

3. Wash $4 x$ with $10 \mathrm{ml}$ of PBST (PBS $+0.1 \%$ Tween 20 ) for minutes.

4. Put membrane in secondary antibody solution (10 $\mathrm{ml}$ Blocking Buffer $+0.2 \%$ Tween $20+0.01 \%$ SDS + secondary antibody (1:15,000)) and incubate for 1 hour at room temperature and gentle shaking (Note: Protect from light from this point on).

5. Pour off solution and wash $4 x$ with $10 \mathrm{ml}$ of PBST.

6. Rinse membrane with $1 \times$ PBS to remove residual Tween 20.

7. Scan membrane in Li-Cor Infrared Odyssey Scanner. 